\title{
O LUGAR DO PAI: \\ SUBJETIVIDADE, CLÍNICA E CONTEMPORANEIDADE - REFLEXÕES A PARTIR DE UMA LEITURA FREUDIANA
}

\begin{abstract}
Dissertação apresentada ao Instituto de Psicologia da Universidade de São Paulo como parte dos requisitos para obtenção do título de Mestre em Psicologia.
\end{abstract}

São Paulo

2003 


\title{
O LUGAR DO PAI: \\ SUBJETIVIDADE, CLÍNICA E CONTEMPORANEIDADE - REFLEXÕES A PARTIR DE UMA LEITURA FREUDIANA
}

\begin{abstract}
Dissertação apresentada ao Instituto de Psicologia da Universidade de São Paulo como parte dos requisitos para obtenção do título de Mestre em Psicologia
\end{abstract}

Área de Concentração: Psicologia Clínica

Orientador: Prof ${ }^{\mathrm{a}}$. Dra ${ }^{\mathrm{a}}$. Isabel Cristina Gomes

São Paulo

2003 
Montserrat, M.T.V.

O lugar do pai: subjetividade, clínica e contemporaneidadereflexões a partir de uma leitura freudiana. / Maria Tereza Viscarri Montserrat. - São Paulo: s.n., 2003. - 134p.

Dissertação (mestrado) - Instituto de Psicologia da Universidade de São Paulo. Departamento de Psicologia Clínica.

Orientadora: Isabel Cristina Gomes.

1. Freud, Sigmund, 1856-1939 2. Complexo Paterno 3. Subjetividade 4. IAMSPE 5. Contemporaneidade (lugar do pai) 6. Psicanálise I. Título. 
MONTSERRAT, Maria Tereza Viscarri. O lugar do pai: subjetividade, clínica e contemporaneidade - Reflexões a partir de uma leitura freudiana. São Paulo, 2003, 134 p. Dissertação (Mestrado), Instituto de Psicologia, Universidade de São Paulo

\section{ERRATA}

\begin{tabular}{|l|l|l|l|}
\hline PÁGINA(s) & LINHA & \multicolumn{1}{|c|}{ ONDE SE LE } & LEIA-SE \\
\hline $\begin{array}{l}13,20,33,42, \\
43,51,69\end{array}$ & $\begin{array}{l}\text { nas citações } \\
\text { indiretas }\end{array}$ & in: ... & Apud: ... \\
\hline $\begin{array}{l}38,39,41,46, \\
47,49,66,108, \\
125\end{array}$ & $\begin{array}{l}\text { nas citações } \\
\text { em } \\
\text { castelhano }\end{array}$ & com, em, um, aum & con, en, un, aun \\
\hline 39 & $2^{\text {a }}$ & dirigido & \\
\hline 61 & $4^{\text {a }}$ & onde & dirigidos \\
\hline 120 & $11^{\text {a }}, 22^{\text {a }}$ & conceitos chaves & conceitos-chave \\
\hline
\end{tabular}

\begin{tabular}{|c|c|c|}
\hline & & Incluir \\
\hline 132 & $18^{\mathrm{a}}$ & $\begin{array}{l}\text { Mayer,H. Mesa-redonda: Histeria. Manifestações } \\
\text { e estrutura. In: Histeria. Porto Alegre. Artes } \\
\text { Médicas, } \\
\text { 1989, Cap.6, p.83-111. }\end{array}$ \\
\hline
\end{tabular}




\section{O LUGAR DO PAI: \\ SUBJETIVIDADE, CLÍNICA E CONTEMPORANEIDADE - \\ REFLEXÕES A PARTIR DE UMA LEITURA FREUDIANA}

MARIA TEREZA VISCARRI MONTSERRAT

BANCA EXAMINADORA

Isabel Cristina Gomes

Ana Maria de Barros Aguirre

Audrey Setton L. De Souza

Dissertação defendida e aprovada em: 31/03/2003. 


\section{Ofereço este trabalho}

\section{Aos meus filhos}

\section{Laura}

... semente de flor amarela

Marcelo

pulsação de vida na imensidão azul... 


\section{AGRADECIMENTOS}

À Prof. ${ }^{a} \mathrm{Dr}^{a}$ Isabel Cristina Gomes, orientadora deste trabalho, pela receptividade, disponibilidade e confiança.

Às professoras doutoras Maria Abigail de Souza e Audrey Setton L. de Souza, pelas valiosas sugestões do Exame de Qualificação.

Aos professores doutores Carol Sonenreich e Giordano Estevão, pela seriedade com que sustentam o espaço de trabalho na Instituição e pela abrangência na transmissão do pensamento clínico - campo de convivência com as diferenças.

Ao Profo. Dr. Zacaria B. Ramadam, pela sua receptividade e especial contribuição.

Ao Oscar Miguelez, com quem aprendi a percorrer os caminhos da psicanálise e a singularidade da sua escuta, agradeço seu acolhimento e suas importantes e ricas sugestões.

À Nora Miguelez, que durante o curso de Formação me proporcionou inúmeras aproximações com a fecundidade do pensamento freudiano.

À minha família com a qual sempre me senti acompanhada, âncora dos meus afetos.

Ao meu pai, José, pela sua dignidade, seu pensar profundo e sua imensa sensibilidade: veia da expressão do belo por meio da imagem e da palavra.

À minha mãe Pilar, com quem aprendi a andar 'na ponta' dos pés, a pisar leve, a brindar a vida com alegria, a sorrir e cultivar os amigos.

À Francisca, minha avó, em memória, com saudades, veia catalã, com quem aprendi a medida da minha força, a lutar e seguir pelos duros caminhos da existência.

Ao Urias Roberto da Silva, pelo tempo que nos foi possível compartilhar a vida....

À Edina Koga da Silva e Laercio Antonio da Silva sempre presentes com seu acolhimento e sua incontável ajuda.

À amiga, Katia Wanderley, pelo incentivo, confiança, especial generosidade e a grande oportunidade de compormos o exercício da nossa amizade no dia-a dia.

À Berenice Neri Blanes, amiga de todas as horas pelos seus ricos comentários, pela sua agudeza na escuta psicanalítica e ilimitada ajuda na minha vida.

À Maria Salete Abrão N. da Silva, com quem tenho aprendido a dividir espaços, a compor novas vivências, sempre generosa com suas sugestões $e$ "alimento" a oferecer.

À "Bia” que me abriu as portas da Instituição, acolhedora e firme na sua confiança sobre o meu trabalho. da alma.

À Maria Cristina Ocáriz, a qual me acompanhou pelos inóspitos abismos

À Yara Rondon Guasque Araújo, amiga de todos os tempos, irmãs na vida, pelo constante estímulo no acompanhamento desta difícil e árdua tarefa.

À Terezinha Almeida Cruz, irmã/amiga de duras batalhas e de luminosas alegrias. muito mais...

Ao Cláudio Barcia Gomez pela presença, pela carinhosa atenção e muito, 
Aos amigos Ricardo Najjar pela referência de um constante afeto e Ana Maria Najjar pelo carinhoso acolhimento, compartilhado no dia-a-dia deste novo espaço inaugurado.

Ao amigo Roberto Cenni sempre ao meu alcance, com toda sua proteção $e$ amizade.

Ao Milton Aponte Junior, por me apresentar as alturas e abismos "nietzschianos" e por todas as sensíveis contribuições.

Às amigas, Aspasia Papazanakis, Mary Santiago, Irani Tomiotto de Oliveira e Áurea Roitman com as quais divido, no dia-a dia, um espaço de incentivos e aportes fundamentais para o meu trabalho e para a minha vida.

À Mariangela Bento reencontro constante com a alegria, um viva pela nossa amizade.

Ao Durval Mazzei Nogueira Filho com suas contribuições “lacanianas” $e$ agudeza nas suas colocações.

À Miriam Debieux Rosa, pela primeira aproximação com a USP me abrindo assim, novos horizontes.

A Roberto Abucham, Alberto Cukier, Salvador Mercúrio Netto, Shalom Kalnicki e Prescilla C. Lindsey que me deram 'a mão' no preciso momento em que a vida estava por um fio.

Aos colegas do Hospital do Servidor Público Estadual pela atenção, incentivo e constante estímulo.

Às colaboradoras Telma, Sara e Niuza, que com disponibilidade e seriedade se prontificaram e me ajudaram na composição final desta tarefa.

Ao Ronaldo, da secretaria de Pós-graduação do Instituto de Psicologia da USP, que graças à sua disponibilidade e compromisso com que realiza a sua função, este trabalho pôde ser encaminhado dentro do prazo. 
Mas que coisa é homem que há sob o nome: uma geografia?

um ser metafísico? Uma fábula sem signo que a desmonte?

Como pode o homem sentir-se a si mesmo, quando o mundo some?

Como vai o homem junto de outro homem, sem perder o nome?

E não perde o nome e o sal que ele come nada lhe acrescenta

nem lhe subtrai da doação do pai? Como se faz um homem?

Apenas deitar, copular, á espera de que do abdômen

brote a flor do homem? Como se fazer

a si mesmo, antes

de fazer o homem?

Fabricar o pai

e o pai e outro pai

e um pai mais remoto que o primeiro homem? Quanto vale o homem?

Menos, mais que o peso? Hoje mais que ontem? Vale menos, velho?

Vale menos, morto? Menos um que outro, se o valor do homem é medida de homem?

Como morre o homem, como começa a ?

Sua morte é fome que a si mesmo come? Morre a cada passo?

Quando dorme,morre? Quando morre, morre?

A morte do homem

consemelha a goma que ele masca, ponche que ele sorve, sono

que ele brinca, incerto de estar perto, longe? Morre, sonha o homem?

Por que morre o homem? Campeia outra forma de existir sem vida?

Fareja outra vida não já repetida em doido horizonte?

Indaga outro homem?

Por que morte e homem andam de mãos dadas

e são tão engraçadas as horas do homem? Mas que coisa é homem?

Tem medo de morte, mata-se, sem medo? Ou medo é que o mata com punhal de prata, laço de gravata, pulo sobre a ponte?

Por que vive o homem? Quem o força a isso, prisioneiro insonte?
Como vive o homem, se é certo que vive? Que oculta na fronte?

E por que não conta seu todo segredo mesmo em tom esconso?

Por que mente o homem? mente mente mente desesperadamente?

Por que não se cala, se a mentira fala, em tudo que sente?

Por que chora o homem? Que choro compensa o mal de ser homem?

Mas que dor é homem? Homem como pode descobrir que dói?

Há alma no homem? E quem pôs na alma algo que a destrói ?

Como sabe o homem o que é sua alma e o que é alma anônima?

Para que serve o homem? para estrumar flores, para tecer contos?

para servir o homem? para criar Deus? Sabe Deus do homem?

E sabe o demônio? Como quer o homem ser destino, fonte?

Que milagre é o homem? Que sonho, que sombra? Mas existe o homem? 


\section{SUMÁRIO}

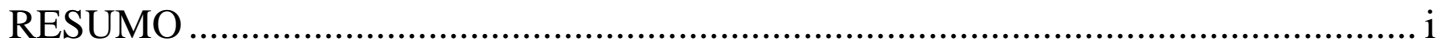

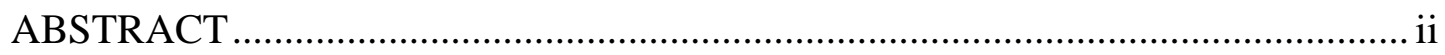

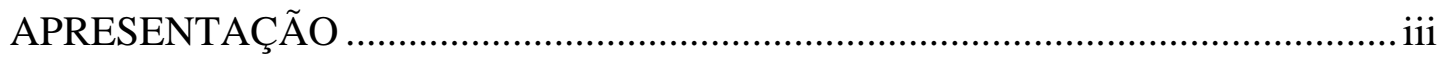

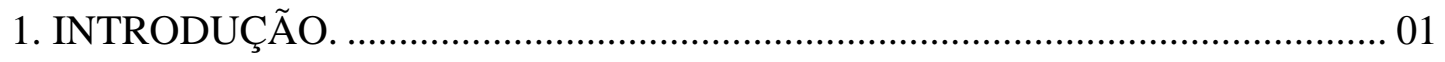

2.UMA TRAJETÓRIA SOBRE A HISTÓRIA DA PATERNIDADE:

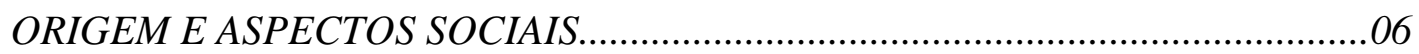

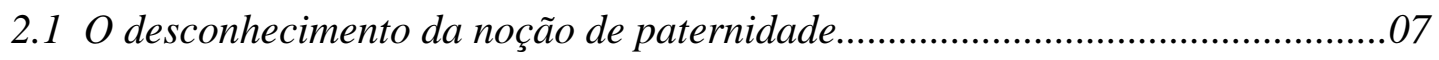

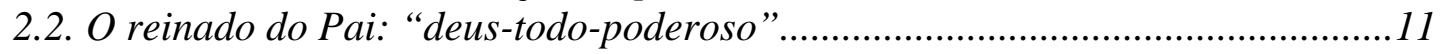

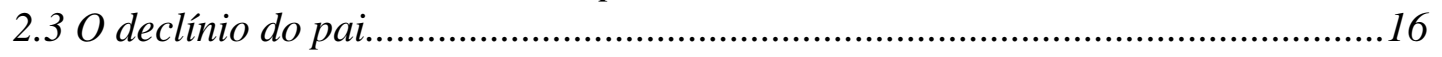

3. O PAI: SEU LUGAR E FUNÇÃO NA PSICANÁLISE........................................19

3.1.O campo da subjetividade - delimitações em Freud.............................................19

3.2 A constituição da subjetividade apoiada nas figuras parentais............................25

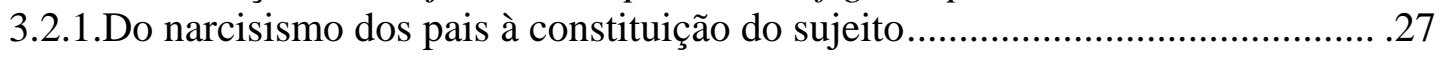

3.2.2.Identificação: campo de sustentação do psiquismo .......................................... 30

3.3. Uma revisão sobre o lugar do pai na teoria freudiana - o complexo paterno....36

3.3.1.A familiaridade com o Édipo: o paradigma do destino humano.........................37

3.3.2.Édipo: da simplificação para a complexidade de sua abrangência .....................44

3.3.3.A conflitiva edípica interpolada pelo narcisismo.............................................. 52

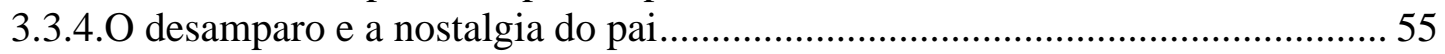

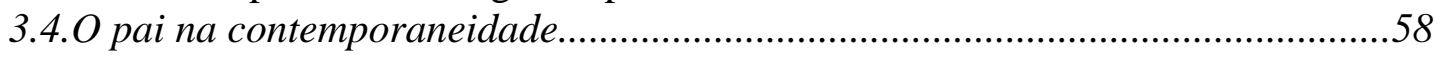

4. DELIMITAÇÃO METODOLÓGICA E CAMPO CLÍNICO ................................6 68

4.1.Considerações sobre o campo de pesquisa em psicanálise....................................68

4.2. Caracterização da demanda e da instituição:a singularidade de seu campo.....70

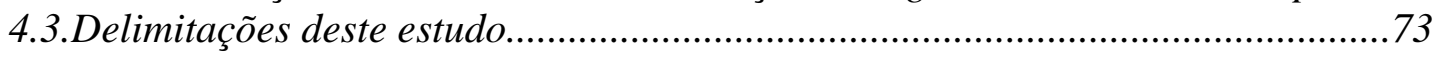

4.4. Apresentação e discussão do material clínico.................................................... 77

4.4.1. Articulação do lugar e da função do pai:
sua importância no cenário das manifestações clínicas.. ..............................108

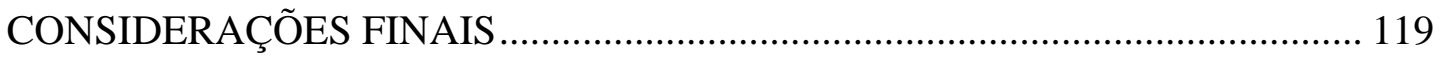

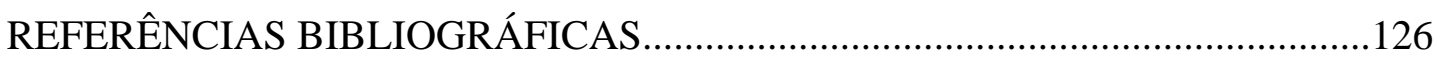




\section{RESUMO}

MONTSERRAT, Maria Tereza Viscarri. O lugar do pai: subjetividade, clínica e contemporaneidade - Reflexões a partir de uma leitura freudiana. São Paulo, 2003. 134p. Dissertação (Mestrado), Instituto de Psicologia, Universidade de São Paulo.

Este trabalho parte de uma inquietação proveniente do atendimento clínico contextualizado na Instituição. Estabelece o delineamento de sua questão, enfocando os aspectos relativos ao lugar e função do pai na constituição da subjetividade e seus reflexos nas manifestações sintomáticas encontradas na clínica com crianças. Define seu eixo teórico num estudo longitudinal do pensamento freudiano a respeito do complexo paterno, visando delinear o fundamento necessário para o encaminhamento de nossa prática. Aponta para a valorização de uma escuta psicanalítica já nas entrevistas preliminares, ressaltando a importância de delinear o lugar do pai na construção de um raciocínio clínico. O conteúdo teórico desenvolvido é ilustrado por meio de recortes do material clínico, obtidos nos atendimentos de pais e crianças, realizados no Hospital do Servidor Público Estadual "Francisco Morato de Oliveira”. Propõe-se, com respaldo neste estudo teórico/clínico, estabelecer considerações sobre o lugar do pai na contemporaneidade, refletindo sobre sua interposição e impasses no contexto institucional e no cenário atual das manifestações clínicas. 


\begin{abstract}
MONTSERRAT, Maria Tereza Viscarri. The father's place: subjectivity, clinical and current times - Reflections from Freud's reading. São Paulo, 2003. 134p. Master Dissertation, Instituto de Psicologia, Universidade de São Paulo.
\end{abstract}

This work is part of unquietness from a clinical heeding in the context of the institution. It establishes the trace of its question, focusing the relative aspects of father's place and function in a way to construct the subjectivism and its reflections about symptomatical manifestations, found in the children's clinic. It defines its theoretical centerline in a kind of longitudinal Freud's thoughts about paternal complex, aiming to trace the necessary basis to give a way to our practice. It points to a valorization from a psychoanalytical hearing, even in the preliminary interviews, distinguishing the importance of tracing the father's place in clinical reasoning. The theoretical content developed is illustrated through pieces of clinical material from father and children's heeding, accomplished in a Public Hospital, named "Francisco Morato de Oliveira”. It has the aim in this theorical / clinical study, to establish some considerations about the father's place in current times, reflecting about its interposition and plights in the institutional context and in the present "wheres and hows" of clinical manifestations. 


\section{APRESENTAÇÃO}

O interesse por este tema surgiu inicialmente, em função dos atendimentos realizados no Ambulatório de Psicologia do Hospital do Servidor Público Estadual “Francisco Morato de Oliveira” (HSPE), a partir dos casos atendidos e supervisionados na área infantil, respectivamente, em psicodiagnóstico, psicoterapia e no atendimento de grupo de pais.

Ao longo deste trabalho, foram se estabelecendo algumas questões de forma sistemática, direcionando especificamente, uma escuta para o lugar e função do pai dentro do contexto e discurso familiar. Assim sendo:

- Onde está o pai e como ele se sustenta perante esta família?

- Qual o sentido de uma freqüente posição periférica do pai, perante o atendimento de seu filho?

- De que maneira as manifestações sintomáticas colocadas pela criança, dirigem-se ao pai como meio de convocá-lo?

- Freqüentemente estas mães procuram uma aliança no sentido de culpar estes pais (este homem) diante dos problemas vividos pelo grupo familiar. Qual o sentido desta manifestação nos dias atuais?

- A instituição acolhe ou exclui este pai, diante destas expressões subjetivas?

Delineada esta demanda, surgiu uma necessidade de fundamentar dentro da literatura uma revisão, inicialmente conceituando e localizando o pai numa perspectiva histórico/social, para em seguida situarmos como foco central de nosso interesse, o pai, enquanto lugar psíquico na constituição da subjetividade do filho e seus desdobramentos nas diferentes configurações conflitivas.

Assim, estabelecemos como eixo principal deste estudo um referencial psicanalítico apoiado nos conceitos freudianos. Delimitamos este campo subjetivo, pela noção de inconsciente, premissa fundamental da psicanálise e pela noção de complexo de Édipo, compreendido como eixo de referência principal na estruturação da personalidade.

Propusemo-nos a seguir esta trajetória dentro da obra freudiana, tanto na sua evolução teórica - recorrendo aos conceitos que metapsicologicamente dão 
fundamento a estas idéias, como também num recorte do lugar paterno na clínica deste autor, que ilustra de forma rica a determinação inconsciente nas diferentes sintomatologias. Apoiados neste referencial, o lugar do pai e sua função adquirem força e operatividade do ponto de vista diagnóstico, quando contextualizado na valorização de uma escuta que fundamente o estabelecimento de um raciocínio clínico. A partir de um atendimento ambulatorial desenvolvido num contexto público, ilustramos este estudo com as manifestações da subjetividade encontradas no atendimento com crianças, pretendendo-se sublinhar como o complexo paterno, articula-se aos respectivos conflitos e queixas (sintomas) encontrados na nossa prática clínica.

A apresentação dos casos teve como seu principal propósito explicitar e articular este corpo teórico, com a nossa atividade prática. Os recortes clínicos que compõem este material foram obtidos nas entrevistas preliminares realizadas com os pais e individualmente com seus filhos, dentro de um processo diagnóstico.

Finalmente, a especificidade da dinâmica institucional entrelaçada às transformações destes novos tempos nos interpelam refletindo-se no dia-a-dia da nossa prática, atravessando pelas inquietações próprias da contemporaneidade o encaminhamento da clínica atual, particularmente quando contextualizada numa Instituição Pública, campo de interface entre o sujeito e o social.

Como conseqüência deste trabalho, recorremos a alguns aportes teóricos de autores que nos auxiliassem a focalizar a questão paterna reeditada na atualidade, no referido enfraquecimento desta imago social do pai, respectivamente identificado nestes novos tempos na crise das instituições e filiações, encontrando-se presente nas diversas ordens de problemáticas e conflitos que compõem este cenário atual das manifestações subjetivas. 


\section{INTRODUÇÃO}

A partir do surgimento da psicanálise, cujos fundamentos encontram-se na obra freudiana, a questão das figuras parentais e sua importância constitutiva na organização psíquica, tem sido sistematicamente abordada por autores de diferentes escolas.

Assim, temos a escola americana com o culturalismo cuja representatividade encontra maior peso no conceito de adaptação e na Psicologia do Ego, tendo sua origem nas idéias de Hartmann (1939); a escola inglesa, cuja representatividade parte das idéias de Klein (1932), na valorização dos fatores constitucionais, destacando principalmente o pólo intrapsíquico, abarcando o estudo dos aspectos primitivos nas relações objetais, elucidativo da relação arcaica com a mãe e por fim a escola francesa cujo ponto de partida situa-se em Lacan (1953) pela valorização do simbólico, na medida em que a ordem de fenômenos de que trata a psicanálise são estruturados como linguagem. Promovedoras de esquemas explicativos divergentes, estas leituras distintas resultam em freqüentes controvérsias, sendo necessário, ao utilizarmos os diferentes conceitos dentro da psicanálise, fundamentá-los de acordo com os princípios utilizados pela referida escola, buscando obter maior sistematização e coerência no pensamento desenvolvido.

No encaminhamento desta revisão, ressaltamos alguns autores que dentro da literatura têm contribuído para a compreensão da formação desta subjetividade na infância, a partir da problematização das funções paterna/materna, tais como Klein (1957), Winnicott (1958), Aberastury (1979), (1984), e pela leitura francesa, Lacan (1949), (1959), Dolto (1965), (1971), (1984), Mannoni (1965). 
Alguns estudos têm sido realizados sobre o tema da paternidade, sua construção e importância na história de vida e desenvolvimento do sujeito. Para tanto, recorremos à dissertação de Carvalho (1989), assim como à tese de doutorado de Silva (1990) que aborda o tema da figura paterna na formação da personalidade, num estudo com adolescentes toxicômanos.

Partindo de um referencial lacaniano a questão paterna tem sido articulada com a clínica da contemporaneidade respectivamente com o chamado "declínio da imago social do pai” através das idéias de Jerusalinsky (1994), Melman (1994), Rassial (2000), entre outros autores como Calligaris (1994), Fleig (2000) Birman (2000) e Kehl (2000) que tem refletido sobre a cultura, a clínica e o mal-estar na atualidade.

Diante do extenso e vasto material que hoje se encontra sobre este tema, composto pela conceituação respectiva às diferentes escolas dentro da psicanálise, entendemos que a leitura de Freud tem sido intermediada por estes diferentes referenciais que, por um lado, têm trazido inúmeras contribuições, dando continuidade e um aprofundamento à conceituação freudiana; por outro lado, esta intermediação - que hoje reconhecemos como impossível dispensá-la - tem nos distanciado do pensamento freudiano, especificamente no que se refere à riqueza de sua transmissão, particularmente no modo de estabelecer um raciocínio clínico, acarretando, por vezes, dificuldade em instrumentarmos nosso trabalho, devido a estas respectivas leituras, tanto na sua dimensão teórica, como também no exercício do pensamento clínico psicanalítico.

Fundamentalmente, numa leitura da obra freudiana, na sua conceituação sobre o lugar do pai - complexo paterno, ponto de partida para a articulação do complexo edípico, encontra-se o eixo teórico referencial deste trabalho, levando-nos a partir das manifestações clínicas contextualizadas na contemporaneidade para reflexões e interpelações sobre a nossa prática, considerando enriquecedor o aporte de autores pós-freudianos que têm se preocupado e refletido a respeito deste novo dimensionamento.

A atividade clínica realizada com crianças e adolescentes não pode ser desvinculada de um discurso parental sustentado pelo desejo, comprometido portanto narcisicamente, revelador de uma história familiar, portadora de uma rede de construções e sentidos, na qual a criança se constitui enquanto sujeito. 
Seguindo, portanto, esta referência, a partir de uma escuta psicanalítica, pretende-se retomar alguns conceitos teóricos, resituando-os dentro da atividade clínica. Num primeiro momento, o narcisismo dos pais que tem um valor constitutivo para o sujeito, desejar o filho, investir nele libidinalmente, dar-lhe um lugar simbólico. Assim, o desejo de um filho só pode ser entendido desde um contexto complementar da libidinização do egoísmo, já que é narcisicamente que se monta este lugar pleno (eu ideal) que todo filho tem que ocupar primariamente. O filho é portanto, o "herdeiro dos pais", tanto no seu aspecto primário do eu ideal como no seu desdobramento futuro, ideal do eu. (Freud,1914)

Num segundo momento, será seguido o eixo do mecanismo de identificação, articulado aos conceitos centrais do complexo de Édipo e complexo de castração, fundamentados na direção proposta por este trabalho, que pretende focalizar o lugar do pai, em termos freudianos, situado respectivamente a partir do campo da referida conflitiva edípica.

Embora o interesse deste tema, tenha partido de um atendimento realizado na rede pública, a manifestação e delimitação desta questão, não está circunscrita apenas ao campo institucional, mas também e principalmente ao campo da clínica, onde esta temática pode ser enfocada. O campo institucional, possibilita uma maior inquietação em função da grande demanda que permite situar sistematicamente este mesmo foco problemático, lançando-nos em direção de questões mais amplas, de ordem social, que nos falam da subjetividade inerente a um grupo e a uma determinada época, compondo também, por sua vez, este cenário de valor estruturante para o sujeito. Simultaneamente este enfoque visa propiciar-nos a possibilidade de subsidiar um serviço ambulatorial da rede pública, na delimitação de pontos, que abram espaço para uma maior operatividade clínica e perspectivas de intervenção, propondo-nos, assim, uma reflexão sobre a rotina deste trabalho.

Neste estudo, pretende-se dentro do momento do psicodiagnóstico (entrevistas preliminares), reunir os pontos fundamentais para o desenvolvimento da nossa prática, ressaltando principalmente a operatividade no raciocínio clínico, articulando a história de vida relatada nestas entrevistas, (pelos pais e pela criança) numa leitura do(s) conteúdo(s) manifesto e latente que compõe a matriz subjetiva, campo de nosso trabalho na clínica. 
Deste modo, tendo como ponto de partida os atendimentos realizados no Ambulatório de Psicologia do HSPE, especificamente focalizando o atendimento de crianças (compreendido nesta instituição até a faixa etária dos 12 anos), demanda esta particularmente expressiva hoje, na ordem das Instituições Públicas, pretende-se valorizar o lugar do pai como campo psíquico/operativo para o estabelecimento do raciocínio clínico dentro das entrevistas preliminares, como também de intervenção e portanto trabalho terapêutico. Neste sentido, faz-se necessário oferecer um espaço para o(s) pai(s), a fim de que se estabeleça a produção de uma subjetividade, onde a nossa escuta enquanto profissional da área da saúde, abra um campo possível de intervenções terapêuticas, no enlace do motivo da consulta próprio da criança com a respectiva problematização da função paterna.

Num contexto institucional, o psicólogo se encontra obrigado a deparar-se em seu trabalho clínico, com situações específicas, tais como: a intensa demanda, a falta de recursos materiais e humanos para o atendimento desta demanda, as dificuldades e conflitos inerentes ao trabalho em equipe, o déficit econômico da população assistida, impossibilitando a vinda sistemática ou prolongada da criança e seus pais, situações estas que atravessam de alguma maneira a nossa prática.

Observamos deste modo, que nem sempre a população encaminhada e atendida na Instituição apresente propriamente uma demanda, embora algo se faça representar com a sua vinda. Esta procura inicialmente delineia, na sua singularidade, um campo de mal-estar que para ser reconhecido necessita de uma escuta. Concomitantemente, não podemos nos omitir frente ao mal-estar próprio dos novos tempos que atravessa as instituições e permeia as vinculações, circunscrevendo um momento histórico com características próprias. O trabalho clínico inserido num campo institucional, situa-nos nesta interface entre o público e o privado, lançando desafios e interrogando-nos no encaminhamento da nossa prática, propondo uma vasta área de reflexão.

Partindo de uma preocupação que já se manifestara em Freud em relação ao campo científico e seu efeito na cultura, autores da atualidade, têm se dedicado ao estudo que diz respeito ao lugar extremamente valorizado da ciência. Neste sentido, Jerusalinski (1994) identifica dentro de um imaginário social, um ideal que aponta para a tentativa de "tornar científica” a criação e educação das crianças; deste modo, os especialistas enquanto representantes deste corpo científico são convocados a gerenciar os problemas de relacionamento que ocorrem em casa entre pais e filhos, 
sendo portanto colocados na intermediação desta problematização das funções paterna/materna. (p.6)

Assim, imbuídos da autoridade que nos foi outorgada, inquieta-nos e incitanos a busca de articulações entre este posicionamento e a questão paterna até o presente momento abordada.

Pretende-se, portanto, com estas idéias aqui lançadas, conduzir este estudo numa retomada dos aspectos conceituais da obra freudiana, dando fundamento para o pai enquanto lugar psíquico na constituição da subjetividade do filho, tendo o cenário histórico/social como pano de fundo, visando sublinhar o atravessamento desta questão dentro da contemporaneidade, contextualizado na compreensão das manifestações subjetivas da clínica com crianças. 


\section{UMA TRAJETÓRIA SOBRE A HISTORIA DA PATERNIDADE: ORIGEM E ASPECTOS SOCIAIS}

\footnotetext{
“...em cada uma das regiões do fazer humano a história é história das rupturas e das continuidades...”
}

(Mezan)

Encontramos na definição da palavra pai, do latim pater, um desdobramento na sua significação, presente no fundamento deste trabalho. Assim, define-se pai:

- "Homem que deu $\operatorname{ser}^{1}$ a outro; homem que tem um ou mais filhos, genitor, progenitor”.

- “Aquele que exerce as funções de pai: pai adotivo” (Ferreira, 1975, p. 1026)

Deste modo, já se estabelece, uma distinção possível entre genitor e pai, a partir dos significados referidos, à medida que cada um se configura em campos distintos respectivamente, o biológico e o social, ou seja, uma distinção entre aquele que gera e o que se coloca no exercício de uma função.

A palavra pai nos remete ainda a outros significados:

- "Designação bíblica da divindade, com relação a toda criação, especialmente ao homem”.

- “Criador, fundador, instituidor”.

- “Benfeitor, protetor”.

- “Causador, gerador; causa, motivo, origem” (Id., ibid.)

\footnotetext{
${ }^{1}$ Grifo nosso.
} 
Na palavra paternidade, do latim paternitare, encontramos:

- "Qualidade ou condição de pai”.

- "Relação de parentesco que vincula o pai a seu(s) filho(s): reconhecimento da paternidade”.

- “Paternidade civil. A que resulta da adoção”. (Id., ibid, p.1055)

Estabelecemos portanto, uma fundamental diferença neste trabalho entre genitor (campo biológico) e pai (campo psíquico/social), que primeiramente será situada e delineada, de acordo com as diferentes épocas e períodos da história, para posteriormente encaminharmos este estudo na sua dimensão teórico/clínica.

\subsection{O desconhecimento da noção de paternidade}

O conhecimento da paternidade é hoje considerado inato, mas de acordo com os estudos desenvolvidos pelos historiadores, depara-se com o fato de que “nenhum ser vivo poderá conhecer as condições fisiológicas da procriação se elas não lhe forem reveladas”. Portanto, “o conhecimento do princípio da procriação não é um dado imediato da consciência como são as noções de nascimento, maternidade e morte, mas sim uma descoberta experimental” (Dupuis, 1989, p..5).

Acompanharemos os estudos e as idéias deste historiador, Dupuis (1989) que assim se refere à descoberta da paternidade, como um acontecimento que se propaga pelo mundo progressivamente a partir do Neolítico, respectivamente no quinto milênio (antes da Era Cristã) numa época denominada Proto-História, período em que os egípcios e os indo-europeus tomaram consciência do papel do pai na procriação. Esta descoberta, levou-o a ordenar a evolução dos povos antigos segundo duas vertentes:

- antes da idéia de paternidade, onde a humanidade não conhecia senão estruturas protofamiliares centradas nas mães, uma vida religiosa inspirada pelo tema da fecundidade feminina, a Grande Deusa de origem Neolítica, período em que a devoção jamais se dirigia ao pai, cuja existência era ignorada e o pênis não aparecia na iconografia; ocorria a prevalência do sistema matrilinear, do parentesco classificatório (onde os termos do parentesco designavam toda uma categoria) e 
conseqüentemente, uma vida sexual caracterizada pela livre satisfação do desejo;

- após a irrupção da idéia de paternidade, onde em conseqüência, organizase ao longo de milênios o sistema patrilinear, estabelecendo-se o parentesco descritivo (cujo termo empregado descreve a pessoa designada) surgindo o que chamamos de família, passando a vida sexual a ser reorganizada segundo uma determinada ordem.

Dupuis (1989) relata que a ignorância da paternidade na humanidade primitiva é demonstrada por um conjunto de provas, pois além da ignorância natural, atestada até o século XX por algumas tribos (australianas, os guajiros da Colômbia, entre outras), deve-se levar em conta os testemunhos da lingüística, da história das religiões e dos costumes.

Em relação aos testemunhos históricos e mitológicos, o autor demonstra que entre os indo-europeus, a mitologia reflete uma sociedade que ignorava o poder procriador do acasalamento, enaltecendo apenas entidades femininas. Em Hesíodo, Teogonia $^{2}$ (apud) encontramos a seguinte passagem:

"Noite gerou a odiosa morte, e a negra Kera, e o Trespasse. Gerou o Sono e com ele toda a raça dos Sonhos, e gerou-os sozinha, sem dormir com ninguém, Noite, a tenebrosa”.

Somente mais tarde é que as representações mitológicas serão dominadas por casais divinos que geram filhos à imagem das famílias humanas, surgindo ao mesmo tempo as representações do falo na iconografia, a partir do momento em que a importância do órgão masculino na procriação é então reconhecida.

Em relação aos testemunhos lingüísticos, encontramos em algumas línguas, a idéia de filiação, de descendência genética, inteiramente associada ao vínculo materno. Em latim, onde frater designa o irmão, a palavra fratuelis aplica-se ao primo, co-irmão materno: indício de que a idéia primitiva de fraternidade referia-se a mãe. (Id.,Ibid., p.5-7)

\footnotetext{
${ }^{2}$ Hesíodo. Trad. P. Mazon. Budé, 1928. Trad. Evelyn White. Loeb, 1974 (1914).
} 
Encontramos também, no relato dos costumes, indícios que atestam ter sido exclusivamente materna a forma primitiva da filiação, particularmente a dos casamentos entre irmão e irmã do mesmo pai, mas de mães diferentes, que explica-se por uma ignorância primitiva do parentesco pelo pai, no lugar do que aparentemente sugeriria uma abolição à lei da exogamia.

Esses casamentos eram permitidos em diferentes culturas, na Arábia anteislâmica, entre os persas, em certas populações do Congo. Outro costume refere-se à forma matrilinear de sucessão dinástica, ou seja, “para deter o poder real, um homem devia tê-lo herdado de sua mãe”, observada por exemplo, no Ceilão e no Egito faraônico.(Id.,ibid., p.8)

Deste modo, somente seria possível a tomada de consciência do princípio de procriação, num contexto que permitiria o controle da sexualidade, surgindo na história, somente no período em que o homem passa a manter os animais em cativeiro, tornando-se evidente que não se podia matar preferencialmente os machos para conservar apenas as fêmeas, porque então elas se tornavam estéreis. Essa experiência, graças a estabilização dos primeiros grupos familiares, numa sociedade agrícola e sedentária, possibilitou uma reflexão nestes povos mais evoluídos da época Neolítica, conduzindo-os progressivamente à aquisição da idéia de paternidade. (Id.,ibid.,p.9)

Ressaltaremos algumas etapas e passagens vividas ao longo da história que segundo as reflexões de Dupuis, fundamentado nos estudos realizados pelos historiadores, antropólogos e etnólogos, foram necessárias para estabelecer esta datação, da descoberta do conhecimento da paternidade. Particularmente, para este trabalho, a importância da constituição da paternidade em termos evolutivos, está na sustentação de um imaginário social e singular de cada época que atravessa o processo de constituição da subjetividade, ditando a valoração dos processos de filiação em diferentes momentos históricos.

Inicialmemte, em função da grande dispersão, provocada pelas condições demográficas da Pré-História a endogamia era uma condição imposta aos grupos humanos, a exogamia, só se tornou possível tardiamente quando o povoamento se fez mais denso.

Sua origem, encontra-se num tabu da Sociedade Paleolítica, anterior ao tabu do incesto e à noção de paternidade, especificamente num tabu fundamental da sociedade caçadora, ou seja, o tabu do "sangue”, que pelo seu escoamento, suscitava 
a angústia nos primitivos. Portanto, desde o princípio da consangüinidade (o grupo como único ser), a perda de sangue por um dentre eles representava um perigo para o conjunto (aspecto este, de forte apego ao grupo consangüíneo, garantindo a subjetivação), surgindo a exogamia como a troca dos sangues com outros grupos, meio pelo qual as sociedades fraternizavam.( Id,ibid,p.35-36)

Segundo Dupuis (1989), cronologicamente temos a primeira organização social conhecida como matrilinear, pois a função procriadora era reconhecida apenas na mulher, neste sistema, os filhos não pertenciam nem a um pai, nem a uma mãe determinados (parentesco classificatório), ocorriam as criações coletivas das crianças, qualquer adulto era chamado de pai e mãe (ausência de sentimento filial pelos pais). Neste sistema a mulher exercia como procriadora uma forte autoridade interna, já que o homem como pai não podia reinar sobre os filhos, pois não os possuíam.

Podemos visualizar esta evolução, compreendendo que na época Paleolítica, os homens tinham dominado a arte e a magia da caça, mas no tempo da agricultura (Neolítico, sistema matrilinear, período das magas, das sacerdotisas, do culto às deusas da fecundação), este saber masculino reduzia-se a um papel secundário, as funções masculinas foram marginalizadas até a idade da guerra e dos heróis. Foram necessários muitos milênios para o estabelecimento do sistema patrilinear, favorecido por circunstâncias históricas, nesta valorização da força física masculina, especialmente conveniente frente ao desencadeamento das guerras, sendo justamente esta revolução patrilinear que permitiu a tomada da consciência da paternidade, devolvendo aos homens sua preponderância, tornando-os senhores da sociedade como reis e como deuses, posteriormente como chefes de família, estabelecendo-se concomitantemente a passagem para o parentesco descritivo. (Id.,ibid., p.9-11)

Caminhando através da memória, nas marcas e registros da história da humanidade, encontramos Ísis e Osíris como um dos casais divinos mais antigos na mitologia egípcia, que permite reconhecer esta tomada de consciência da paternidade.

$\mathrm{Na}$ família do grande rei Osíris, encontra-se simultaneamente, uma pluralidade de pais e mães, situando-nos assim, na confluência de dois tipos de sociedade: o parentesco classificatório, situa Osíris numa Sociedade Neolítica, sem famílias, onde temos grupos humanos que procriam coletivamente, ao mesmo tempo, Osíris é considerado como o "fundador” da família monogâmica e nuclear em 
que se converterá a família do Egito. Portanto, temos aqui o "testemunho de uma sociedade que toma consciência da paternidade e que começa a constituir a família em torno do casal masculino-feminino. Testemunho dessa sociedade, o grande rei transforma-se naturalmente em seu símbolo”, como figura nos Textos das Pirâmides (apud) $)^{3}$ gravados na pedra por volta do terceiro milênio, aludindo à paternidade de Osíris:

\section{Porque sou Hórus \\ Vim seguindo meu pai, \\ Vim seguindo Osíris.}

Assim como o mito Ísis/Osíris permite estabelecer uma datação da consciência da paternidade em relação à história egípcia, historiadores encontram a mesma correspondência entre os indo-europeus na China Neolítica e na América précolombiana, entre a civilização maia, onde ao longo da história destas diferentes culturas, encontram-se os símbolos fálicos surgindo universalmente em determinado estágio evolutivo dessas sociedades, como uma constatação de uma tomada de consciência do princípio masculino da procriação.(Id.,ibid, p.13-19)

\subsection{O reinado do pai: “deus-todo-poderoso”}

A família nasce portanto na chamada idade dos heróis, a fundação da família é um ato de violência que desloca os antigos clãs matrilineares e faz surgir pouco a pouco uma nova sociedade, onde juntamente com as famílias, os conquistadores fundam reinos apoiados em seu poderio, as religiões e a moral tornam-se, por sua vez, expressões do domínio masculino.

Surge o comportamento despótico do herói que se impõe aos seus contemporâneos por sua força excepcional e sua potência sexual. Nas sociedades arcaicas (matrilineares) não havia o indivíduo autônomo, mas o indivíduo coletivo, imerso completamente no seu grupo. O indivíduo só começa a separar-se da matriz coletiva pela afirmação pessoal dos heróis, chefes vencedores. Apropriando-se da família patrilinear, por eles fundadas, os heróis deslocam os velhos quadros sociais,

\footnotetext{
${ }^{3}$ Pirâmides(Texto das). The Ancient Egyptiam Pyramid Texts. Trad. R. O. Faulkner. Oxford, Clarendon Press, 1949, 2 vls
} 
erigindo acima dos clãs as monarquias guerreiras. Assim, os casamentos por rapto vão dando lugar gradualmente aos matrimônios por compra, permitindo compreender o casamento como uma instituição de classe.(Id.,ibid.,p.90-99)

Dupuis (1989) faz ainda interessantes considerações a respeito do incesto (infração sexual cometida em graus de parentesco interditos) inserindo-o também nesta cronologia histórica, situando-o como um conceito tardio, de origem patrilinear, pois segundo sua etimologia latina, in-castus, ele significa "não-casto, impudico, não religioso".

O conceito de incesto traz em si mesmo a conotação de pecado sexual que decorre da moral patrilinear, enquanto as Sociedades Matrilineares Neolíticas ignoravam a castidade. Entre todas as formas de incesto, o praticado com a mãe ocorreu primeiro sendo de forma global, pois a criança conhecia apenas "as mães” de sua comunidade, justificando-se assim, a obrigação dos acasalamentos sexuais com um gupo não-consanguíneo, onde segundo o autor, identificamos a origem das primeiras migrações interclãnicas, que foram migrações de rapazes. Somente com o conhecimento da paternidade, com a prevalência do sistema patrilinear e o estabelecimento do parentesco descritivo, passa a ser condenado o incesto com o pai e posteriormente o incesto entre irmãos. (Id.,Ibid., p.107-115)

Este mesmo autor nos permite ainda, através de seu rico trabalho entender como se processou ao longo da história as diferentes funções assumidas pela paternidade.

No sistema matrilinear, o vínculo afetivo maior das famílias antigas era o da mãe com seus filhos e principalmente seu filho, daí decorre uma focalização dos grupos familiais ao redor da mãe (origem da matrifocalidade das sociedades tradicionais), os maridos pertenciam à sociedade de homens na qual viviam e os pais estavam distantes dos seus filhos, encontrando-se totalmente dissociados da educação desses, pois era desconhecida neste período a paternidade genética. Posteriormente, ocorre o surgimento da função sociológica da paternidade, onde a valorização do filho é indispensável à perenidade do novo grupo familiar, já que este grupo é patrilineal.

Nas civilizações indo-européias, o adjetivo “patrius” refere-se não ao pai físico, mas ao pai do parentesco classificatório. Assim a descendência social e jurídica é a "patria potestas” , vinda dos pais fundadores. Neste sentido, ressalta-se aqui não o caráter biológico, mas cultural . De um primeiro sentido do pai enquanto 
soberano deslizaremos ulteriormente para a paternidade familiar, para o chefe da casa.(in: Julien,1997, p.37-38)

Segundo Ariès (1978) na origem da cultura européia, a paternidade é adotiva e voluntária. Na Roma antiga após o nascimento, a criança era submetida a uma espécie de nascimento não biológico, sendo posta na terra diante do pai que a elevava acima do solo, fazendo publicamente seu reconhecimento, sua adoção.( in: Julien,1997,p.37-38)

Portanto, “o pai constitui antes de tudo uma instituição: é a entidade que garante a continuidade do grupo”. (Dupuis, p.136)

Pai e filho, elos de uma corrente que assegura a continuidade de uma linhagem que por sua vez, garante a continuidade de um grupo biológico e de uma classe social. Desta forma, a fundação familial faz surgir uma nova autoridade absoluta que é a do pai, tendo o direito de vida e morte sobre os filhos, possibilitando à família transmitir aos descendentes seus bens, poderes e tradições.

Com este advento, ocorreram grandes transformações: surge a apropriação privada das terras, a religião passa a sustentar uma moral baseada na família patrilinear, em oposição à concepção orgiástica do período arcaico, ocorrem mudanças profundas no estatuto da mulher. Com a aproximação da Era Cristã, as meninas e mulheres devem permanecer sob a dependência do parente masculino mais próximo.

Temos aqui a imagem do casal gerador de filhos, mas este casal antigo difere do moderno, pois não é constituído por um vínculo amoroso entre o homem e a mulher, atendendo a um objetivo privado de transmitir patrimônio a descendentes e perpetuar uma política de castas. O culto dos ancestrais era sempre um culto de patrilinhagem, assegurado por machos que valorizavam o filho, habilitado por sua vez, a perpetuar a linhagem paterna.(Id.ibid. p.140-153)

Assim, as mudanças vividas dentro das diferentes organizações sociais, políticas e econômicas, refletem-se claramente na religião e na arte de um povo. Sua cultura se inscreve ao longo do tempo, permitindo recuperá-la nas marcas da história. Pretendemos com este percurso, localizar o lugar do pai em diferentes épocas da humanidade, resgatando algo da ordem de um imaginário social que atravessa e portanto, também compõe as vicissitudes da constituição psíquica. 
Dentro desta retrospectiva histórica, mencionaremos alguns momentos importantes, que de acordo com Ariès (1978) são reveladores dos laços sociais e familiares.

Desse modo, antes da Idade Média, não havia propriamente um “sentimento da família”, tratando-se até aqui, da solidariedade da linhagem permanecendo uma valorização dos laços de sangue, cujas características essenciais, eram a indivisão do patrimônio que significa o direito coletivo sobre o conjunto destes bens. O fortalecimento dos laços de sangue correspondia basicamente a uma necessidade de proteção, assim como outras formas de relações humanas e de dependências, tais como a suzerania e a comunidade aldeã. Não havia também uma distinção clara entre o profano e o sagrado, nem entre o privado e o público, mas sim algo como um prolongamento entre ambos, cujo cenário era a Rua Medieval onde tudo se passava. Segundo os arqueólogos encontra-se sistematicamente presente na iconografia o “tema dos ofícios”, deixando claro que a vida privada de um homem era seu ofício.

O sentimento de linhagem era o único sentimento de caráter familiar conhecido até a Idade Média, sendo muito diferente do sentimento de família, pois não levava em conta os valores nascidos da coabitação e da intimidade, ao contrário do sentimento da família que está ligado prioritariamente à vida na casa.( Ariès, 1978, p.195-223)

O direito de primogenitura, segundo Ariès (1978) passa a ser difundido nas famílias nobres, aproximadamente no século XIII, substituindo a indivisão do patrimônio e sua integridade, sinalizando também a importância atribuída à autoridade paterna e do lugar assumido na vida quotidiana pelo grupo do pai e seus filhos.

Avançando ao longo da Idade Média, gradualmente constata-se uma transformação deste tema, onde o homem não aparece mais sozinho com o seu ofício, mas aglutina pessoas nas mais variadas representações iconográficas, configurando ao seu redor a presença da família, surgindo ao seu lado primeiramente a figura da mulher e posteriormente das crianças inaugurando no século XVI a imagem da família, constituindo-se historicamente num "sentimento da família”.

A morte do patriarca acompanhada por toda a família, registrada na iconografia, testemunha a presença deste sentimento novo: o sentimento da família, agora também na intimidade da vida privada, inseparável do sentimento de infância, 
onde a criança outrora periférica, vista como insignificante, compartilhando dos trabalhos e jogos do adulto, passa no século XV-XVI, a ter um lugar de importância.

Neste período histórico, segundo Ariès (a partir do século XVI), encontramse registros do hábito de se insistir nas semelhanças físicas entre pais e filhos, acompanhado justamente da emoção despertada pela criança por corresponder a imagem viva de seus pais, através da semelhança com seus genitores.(Id.,ibid., p.223-224)

A vida até o século XVII era vivida em público, as pessoas viviam misturadas, ou seja, adultos e crianças, senhores e criados. Com o surgimento da família, instala-se algo da ordem como uma "sociedade fechada", surge a vida privada e espaços que preservam a intimidade e as novas necessidades de conforto.

Concomitante a estes sentimentos novos - da família, de infância estabelecidos gradualmente, mantém-se ainda forte, prevalente a autoridade paterna. Os termos empregados pelos moralistas para designar os deveres de um bom pai de família eram: "aprender a controlar sua mulher, bem educar seus filhos e bem governar seus criados”. Neste cenário histórico, vemos claramente a perda de autonomia feminina, articulada ao progressivo e concomitante fortalecimento do regime do patriarcado.(Id.,ibid., p.263)

Ao percorrermos estas mudanças e transformações da família, podemos dimensionar as modificações nas relações internas ocorridas dentro do grupo familiar, permitindo-nos rastrear os diferentes lugares e funções relativas a cada membro deste grupo. Paralelamente, este processo de transformações e mudanças também se manifesta na educação da época. Deste modo, a família que inicialmente enviava as suas crianças (a maioria meninos, aproximadamente aos sete anos de idade) para outras famílias estranhas, para casa de um mestre, as quais teriam por sua vez, a incumbência de transmitir formação a elas (não ao seu filho, mas ao filho de outro homem), sofre uma transformação a partir do século XVII ao concentrar-se gradualmente em torno do próprio filho, nascendo então a família moderna, justamente no mesmo período em que surgem as escolas como forma de manter a educação das crianças garantindo a permanência destas com seus pais.(Id.ibid.,p.225270)

No século XVIII, a família começou a manter a sociedade à distância, surgindo uma necessidade nova de isolamento, estabelece-se cada vez mais uma maior discriminação da vida mundana, da vida profissional e da vida privada, sendo 
para cada uma delas, determinado um local apropriado. Portanto, passamos da família aberta para o mundo para a família isolada, característica da modernidade, “onde toda energia do grupo familiar é consumida na promoção das crianças, cada uma em particular e sem nenhuma ambição coletiva: as crianças mais do que a família”. (Id.,ibid., p.271)

Para Ariès (1978) “a família conjugal moderna seria portanto a conseqüência de uma evolução que no final da Idade Média teria enfraquecido a linhagem e as tendências à indivisão”. Este novo sentimento da família observa ainda este autor, vem ao encontro do sentimento de classe, onde há nitidamente manifestações de intolerância diante das diferenças, diante de qualquer diversidade, aspecto que se encontra nas raízes da uniformização e homogeneidade particularmente valorizadas na modernidade. (Id.,ibid., p.211)

\subsection{O declínio do pai}

Do social público passa-se ao social privado, ou seja, do poder do soberano, passa-se ao poder no interior da própria família, ocorrendo uma modificação qualitativa deste poder.

Gradualmente, nesta passagem da Idade Média para a Idade Moderna vamos nos confrontando cada vez mais com este processo de substituição do discurso religioso pelo discurso científico; “o saber suposto em Um”, outrora defendido e imposto pela Inquisição, não encontra sustentação num período em que a lei se divide entre lei natural e lei civil, dando origem a dois saberes, o da Ciência e o da Teologia que se torna então Filosofia, uma Filosofia Política.

Na Inglaterra deparamo-nos no século XVIII com a ascensão da burguesia, fim do absolutismo do rei, em pleno assentamento da Revolução Industrial. Por sua vez na França, com a Revolução Francesa (1789) fundada sobre a fraternidade/igualdade e não sobre a paternidade, onde o rei é executado, emblema de um parricídio, o poder também abandona o direito divino, sinalizando concomitantemente em diferentes instâncias, diversas crises e em conseqüência mudanças nos sistemas de valoração que tecem novas posições e relações dentro do social. (Rassial,2000) 
Assim com o Iluminismo, com o advento do ideal burguês do século XIX e o Humanismo, “o homem e sua razão” estão colocados no centro do mundo, desalojando o poder divino pela mediação da ciência. Observamos que a autoridade paterna que outrora concernia de forma indivisível às sociedades político/religiosa e familiar, centra-se exclusivamente sobre a família como ideal burguês, sofrendo a definição do ser-pai um declínio constante. A intervenção crescente do Estado e da Justiça visando a defesa dos direitos da criança como o papel insubstituível atribuído à mãe, enaltecendo este amor maternal, contribuem e atestam para esta insuficiência que se instala, desta vez, no lugar e função do pai.

Conforme Birman (2000, p.39), desencadeia-se todo um processo de lutas e busca de igualdade entre os sexos que começa a se esboçar com o feminismo, já como uma das decorrências da manifestação subjetiva da "humilhação do pai” (assim referido por Lacan dos anos 40) e considerado ao nível propriamente sociológico, o representante da perda da tradição patriarcal.

Ao nível teológico e filosófico, ainda segundo Birman, esta referência à "humilhação do pai” participa da grande temática da filosofia nietzschiana que atravessa o século XX, culminando com a questão da morte de Deus, secundada pelo pensamento de Heidegger, abalando a já frágil e desfalecida sustentação da função do pater da família patriarcal por correspondência à figura divina, com os preceitos de Deus.

Ainda apoiado no direito da criança, surge uma tentativa tímida nos modismos imperativos do século $\mathrm{XX}$, na recomposição do lugar paterno, com o chamado "novo pai”, aquele que se ocupa em termos de papéis a cumprir e tarefas a realizar, função esta que não se sustenta na medida em que outros igualmente capazes podem se ocupar, intervindo neste frágil terreno os profissionais com seus laudos e estudos de última geração, especificando os melhores cuidados e assistência visando o suposto bem da criança. (Julien,1997, p.45-48)

Surge mais um golpe com a ciência e sua mais recente e inovadora noção de “paternidade biológica”, o saber científico associado a mais alta tecnologia, perfeitamente amparados pela lei, aliam-se na busca cada vez mais precisa da determinação do lugar do pai. Passo a passo chegamos à “partícula pai”, tão diminuta que só com o auxílio de poderosos instrumentos e laboratórios a complexidade da filiação poderá ser vista, precisamente localizada e por fim entre cálculos e tropeços encontrar o seu pressuposto fundamento... 
Colhidos os espermatozóides, o pai está dispensado!!

É nesta conjunção histórica da crise da identificação do criador, do legislador, aquele que está na origem e aquele que representa a lei, portanto, da crise desta função unificadora que procuraremos rastrear o lugar e a função do pai nestes novos tempos. 


\section{O PAI: SEU LUGAR E FUNÇÃO NA PSICANÁLISE}

\subsection{O campo da subjetividade - delimitações em Freud ${ }^{4}$}

Partimos de Freud (1856-1939), por ser o criador da psicanálise na perspectiva de referências conceituais que nos instrumentam no estabelecimento de um raciocínio clínico. Assim teoria e clínica seguirão de forma conjunta nesta nossa trajetória.

Com o intuito de delimitar o campo da subjetividade ao terreno da Psicanálise, distanciando-o de sua aplicação feita tanto pela Filosofia como a Psicologia, determinamos a noção de inconsciente e a noção de complexo de Édipo, como eixos de referência teórica para conduzir este estudo. Dentro da obra freudiana é necessário ainda dimensionarmos do ponto de vista psicanalítico, o psiquismo dividido em dois sistemas, inconsciente e consciente, pressupondo que falar em subjetividade em termos individuais, implica previamente na ação do recalque. Para a psicanálise, o aparelho psíquico constitui-se a partir de inscrições desprendidas dos primeiros objetos sexualizantes que originam as moções pulsionais e propriamente, é a partir da constituição de uma ordem simbólica do inconsciente, que falamos em sujeito $^{5}$ e em subjetividade, já que é no campo da palavra, que nos movimentamos com este corpo teórico.

Ao delimitarmos o campo da subjetividade em psicanálise foi preciso acompanhar a trajetória de Freud em busca da compreensão do psiquismo humano. Deparamo-nos com uma tarefa complexa, quando nos propusemos a seguir o desenvolvimento conceitual de sua obra, considerando as diferentes versões que

\footnotetext{
4 As instâncias que na obra são referidas como Es / Ich / Über-Ich, diferem nas diversas traduções do original. Ao longo deste estudo, manteremos os correspondentes Isso / eu / supereu.

5 Definido aqui como o próprio homem, na sua singularidade e dentro da concepção freudiana, submetido aos processos próprios do inconsciente.
} 
foram se estabelecendo em relação ao modelo de aparelho psíquico, ao longo do tempo. De acordo com a cronologia da obra, pudemos nos deter em três momentos distintos, correspondentes ainda aos textos pré-psicanalíticos, considerados como preparatórios no encaminhamento posterior da construção do aparato psíquico. (Garcia-Roza, 1991)

Inicialmente no texto das Afasias (1891), enquanto toda a atenção dos neurologistas na época voltava-se para a localização de uma área cerebral responsável pelos distúrbios afásicos, Freud destaca a perturbação na linguagem como ponto essencial nesta ordem de distúrbios, introduzindo o termo aparelho de linguagem que funcionaria em termos de processos, destacando os elementos psíquicos (representações) dos elementos sensoriais. Resgata como elementos aí envolvidos: a linguagem, a memória, a representação e a associação, onde as rupturas associativas e a interrupção na condução é o que vai determinar a afasia. Freud acentua com estes processos que pessoas sem nenhuma lesão cerebral podem apresentar afasias, como decorrência de causas e situações emocionais. Neste artigo, estamos diante das primeiras articulações teóricas de Freud em torno de uma noção prévia de funcionamento psíquico inconsciente. (in: Garcia-Roza,1991)

Posteriormente, em o "Proyecto De Una Psicologia Para Neurologos" (1895), Freud preocupa-se em explicar o funcionamento psíquico, distanciando-se nitidamente das explicações anatômicas e neurológicas. Garcia-Roza (1991) propõe pensarmos que, neste momento, Freud desenvolve uma teoria do psiquismo, incluindo a perspectiva da subjetividade, na medida em que destaca pela primeira vez a noção de vivência de satisfação, procurando descrever o momento inaugural do psiquismo humano. Aqui Freud conceitua os afetos e os estados de desejo, onde o relato da experiência de satisfação está embasado no estado de desamparo original do ser humano. Esboça, ainda, o aumento de tensão no aparelho psíquico sugerindo a hipótese da existência de uma organização no sistema para administrar a passagem de quantidades de tensão: primeira menção do que vai constituir o conceito do "eu" para a psicanálise. Esboça a idéia de processos psíquicos primários e secundários, procurando fazer uma descrição da forma de funcionamento do aparelho apoiado na Física, especificamente na termodinâmica, procurando estabelecer o conceito de investimento e estabelecer leis de funcionamento (lei da constância: princípio que evita o escoamento de energia). Descreve um aparato composto por três sistemas, assim como modos reguladores do aparelho, desenvolve as noções como 
investimento colateral, barreira de contato e facilitações, privilegiando portanto a concepção econômica. Traduz o conceito de consciência como "la faz subjetiva de una parte de los procesos físicos que se desarrollan en el sistema neuronal” (Freud,p.224), estabelecendo estas importantes formulações, abrindo caminho para as elaborações posteriores do modelo do aparelho psíquico.

Num terceiro momento, situado entre os textos pré-psicanalíticos temos a Carta 52 a Fliess (1896) onde Freud caracteriza o aparelho numa nova dimensão, especificamente como um aparelho de memória, apresentando as noções de “inscrição”, “signo” e “transcrição”. Desenvolve uma noção que já estava no Projeto, de uma memória e de um psiquismo constituídos por diferenças de acordo com os caminhos que a excitação percorre. Esse modelo de aparato opera com marcas transcritas e retranscritas, funcionando como registros sucessivos que correspondem à realização psíquica destes momentos. No limite entre estes momentos, deve ocorrer uma tradução do material psíquico, tradução esta que pode não ser completa. A falha na tradução corresponde ao que se pode observar clinicamente como processo de repressão. Com esta carta, propõe o encaminhamento definitivo de seus pressupostos teóricos na conceituação da primeira tópica.

Em “La Interpretacion de Los Suenõs” (1900) Freud estabelece o caminho principal para a descoberta do Inconsciente, propriamente no capítulo da "Psicología de Los Procesos Oníricos”, analisa a estrutura e a função do aparelho psíquico através da identificação dos mecanismos constitutivos do processo onírico (deslocamento, condensação, simbolismo) também reencontrados noutras formações inconscientes (atos falhos, lapsos...) guardando por sua vez, equivalência aos sintomas pela sua estrutura de compromisso e pela sua função de realização de desejo, configurando o campo das formações substitutivas de caráter simbólico.

Inicialmente, dentro de sua primeira teoria do aparelho psíquico, composto pelas três instâncias - respectivamente, Inconsciente, Pré-consciente e Consciente Freud designa o Inconsciente como um desses sistemas constituído por conteúdos recalcados, cujo acesso destes conteúdos ao sistema Pré-consciente e Consciente encontra-se recusado de forma direta, sendo possível este acesso somente através das formações de compromisso. Estes conteúdos são representantes das pulsões, regidos pelos mecanismos do processo primário -condensação e deslocamento - fortemente investidos pela energia pulsional - energia livre - comportando ainda, os traços 
mnemicos relativos às primeiras vivências de satisfação nos quais a pulsão se fixa, delineando-se nesta instância o campo do desejo.

É justamente para Freud com o recalcamento infantil que se opera propriamente a clivagem entre o Inconsciente e o sistema Pré-consciente/Consciente.

O modelo de aparelho psíquico a partir desses conceitos está embasado na valorização da posição relativa dos sistemas, trabalhando com uma noção de lugar que é metafórica e não anatômica. Este aparelho da primeira tópica é orientado na direção progressiva-regressiva, formado por sistemas, caracterizado pelo conflito entre estas instâncias, onde circulam o desejo e as idéias investidas.

A segunda tópica freudiana surge a partir de 1920, neste longo percurso encontra-se a elaboração da parte mais significativa da produção metapsicológica de sua obra. Estes acréscimos teóricos desencadeiam uma reformulação do aparato psíquico que gradualmente vai se remodelando no decorrer destes anos com o surgimento deste conjunto de novas idéias propostas. Situaremos neste contexto: o conceito pilar de narcisismo (1914) e seu decorrente desdobramento em eu ideal e ideal do eu; o conceito de compulsão à repetição, surgindo inicialmente como objeto autônomo de sua reflexão já no artigo “Recuerdo, repetición y elaboración” (1914) como uma das dimensões constitutivas do Inconsciente, sendo vinculado à noção de transferência; a idéia da clivagem entre uma parte crítica do eu e o próprio eu, como é postulado em "Duelo Y Melancolia" (1917), compondo parte da série compreendida como textos metapsicológicos e principalmente após, “Mas Alla Del Principio Del Placer” (1920) onde Freud sublinha a grande parte inconsciente do eu, propondo-se a partir da observação dos fatos cotidianos como o "Fort-Da" e da repetição de episódios dolorosos (tal como se evidenciava nas neuroses de guerra) desenvolver com maior densidade sua reflexão sobre o processo inconsciente inerente à repetição, não sendo mais possível a partir deste momento, preservar o modelo anterior do aparato psíquico, sendo necessário introduzir uma nova dualidade pulsional denominada como: pulsão de vida e pulsão de morte.

Na segunda teoria do aparelho psíquico, eleva à categoria de instâncias o Isso (ello/id/es, em alemão) considerado como polo pulsional, o eu (yo/ego/ich) como agente da defesa, mediador entre a realidade externa e as demais instâncias e o supereu (super-yo/super-ego/über-ich) como sistema de interdições, compondo no seu aspecto funcional, as funções da consciência moral, da auto-observação e da formação de ideais. 
Este modelo do aparato psíquico já não está mais baseado nas ciências físicas mas está marcado pelo antropomorfismo, onde o campo intra-subjetivo passa a ser concebido segundo o modelo das relações inter-subjetivas, aproximando-se da forma fantasmática de como o indivíduo se constrói. (Laplanche e Pontalis, 1983, p.661)

Especificamente é no texto “El Yo Y El Ello” (1923), que desenvolve estas formulações teóricas, onde o inconsciente (depósito da libido) deixa de ser identificado como instância especial, e passa a qualificar o Isso, no qual reencontramos as suas principais características mas que em parte, também qualifica o eu e o supereu, sendo o inconsciente compreendido neste sentido como o conjunto dos conteúdos não presentes no campo atual da consciência, mas cujo valor dinâmico mantém-se preservado - o inconsciente reprimido.( Laplanche e Pontalis, 1983)

A partir daí, o conceito de eu vai ser retomado, elaborando a noção de um eu corporal, constituído como uma projeção da superfície corporal, estabelecendo-se por um lado sua ligação com a consciência, funcionando como uma organização coerente dos processos mentais em contato com a realidade exterior (entidade que tem início no sistema perceptivo), regendo o controle sobre a motilidade, exercendo censura sobre os sonhos, representando o pólo defensivo da personalidade, constituindo-se num registro que repousa sobre o Isso, não sendo encontrado propriamente separado dele, pois se funde com ele em sua parte inferior. Por outro lado, é compreendido como o resultado de identificações, onde enfatiza os seus efeitos estruturantes, levando-o a estabelecer a origem do ideal do eu, onde "detrás de el se oculta, la primera y más importante identificación del individuo, o sea, la identificación con el padre”. Freud observa posteriormente a necessidade de maior cautela neste momento considerando mais prudente afirmar "con los padres", levando em conta a valoração indistinta da criança em relação às figuras parentais antes da descoberta da diferenciação sexual. (Freud, 1923, p..2708-2712).

Chegamos neste ponto na gênese do supereu, resultado em parte pela condição infantil de dependência e desamparo, em parte de natureza histórica centrada no complexo de Édipo, inscrição simbólica das relações familiares, elemento primordial na orientação do desejo humano. 
As duas tópicas acima referidas permitem uma visualização ampla de diferenças conceituais importantes que tem influenciado, em maior ou menor grau, as leituras posteriores e suas respectivas orientações na compreensão da constituição psíquica e suas manifestações subjetivas a partir da noção do Inconsciente, premissa fundamental da psicanálise. Se na primeira tópica freudiana a finalidade da análise era tornar consciente o inconsciente, na confiança que os efeitos sintomáticos do recalque se desfariam pela interpretação; na segunda tópica, essa finalidade desemboca na interpretação do Édipo, cuja plena superação vai ser sempre interrogada ao longo de sua obra, questão esta amplamente abordada nos textos ulteriores, sinalizada na referida "nostalgia do pai”.

Neste percurso tocamos em outro eixo norteador deste estudo referente ao complexo de Édipo e seu valor estruturante. Propomo-nos a seguir, um trajeto também cronológico dentro da obra freudiana, acompanhando gradualmente as elaborações construídas sobre este conceito que compõe o objetivo deste trabalho. 


\subsection{A constituição da subjetividade apoiada nas figuras parentais}

Resíduo

"Pois de tudo fica um pouco. Fica um pouco de teu queixo no queixo de tua filha. De teu áspero silêncio um pouco ficou,um pouco...”

(Drummond)

A importância das funções materna/paterna na constituição do psiquismo já tem sido ressaltada amplamente na literatura por diferentes autores, abordaremos o desenvolvimento deste tema dentro do pensamento freudiano.

Para o seu desenvolvimento colocaremos em evidência o conceito de libido (do latim: desejo) onde do ponto de vista de Freud, configura-se como o principal determinante da psique humana, designando propriamente a manifestação da pulsão sexual na vida psíquica, sendo construído a partir daí, o que passou a ser denominado em sua obra de Teoria da Sexualidade, já enunciada em “Tres Ensayos para una Teoria Sexual” (1905) .

Componente essencial da sexualidade como fonte do conflito psíquico, Freud vai integrar este conceito de libido na definição de pulsão e na relação de objeto (libido objetal) e por fim a partir de 1914, reencontrá-lo numa identidade narcísica (libido do eu).

Já neste percurso inicial a pulsão (derivado do latim: pulsio, para designar o ato de impulsionar) conceito que se diferencia de instinto, na medida em que não é fixado por hereditariedade como um comportamento animal, não possui objeto fixo e não é pré-formado em seu desenvolvimento, assume enquanto processo dinâmico o lugar de um grande conceito na teoria psicanalítica.

Será em 1915 no contexto do projeto freudiano de uma metapsicologia sob o título: “Los instintos y sus Destinos” que este autor recapitulará este tema da pulsão, relembrando seu caráter limítrofe (entre o psíquico e o somático) passando a enumerar suas quatro características: primeiramente a sua “força” ou “pressão' constituindo-se na sua essência e motor da atividade psíquica, o “alvo” cujo elemento principal é sua satisfação, o “objeto” cujo valor é outorgado pela libido, não sendo nunca próprio e a "fonte” das pulsões referindo-se ao processo somático, localizada numa parte do corpo ou em um órgão, cuja excitação é representada no psiquismo pela pulsão. 
É nesta retomada da fonte pulsional que comporta-nos tratar de zonas erógenas e pulsão parcial, sublinhando seu caráter polimorfo, um dos eixos de compreensão da sexualidade infantil. Neste sentido as figuras parentais assumem um lugar de destaque neste despertar da sexualidade da criança, momento inaugural que se encontra apoiado nos primeiros cuidados necessários à sua sobrevivência. Lembremo-nos que sexualidade deverá ser sempre compreendida e articulada a toda uma série de excitações e atividades promovedoras de prazer desde a infância não comportando reduzi-la à genitalidade.

Podemos então, articular as diferentes etapas da organização libidinal que ao longo da obra foram sendo conceituadas (e posteriormente condensadas nas ulteriores revisões de sua Teoria Sexual) aos diferentes modos de relação com os primeiros objetos e sua conseqüente importância na construção do psiquismo, assim como, na determinação das futuras escolhas objetais.

Correspondente a um modo de relação com o objeto próprio da organização oral, teremos a vivência subjetiva da dedicação integral do objeto (considerando-se o referido desamparo biológico do ser humano após o seu nascimento) compreendida como algo da ordem de um "amor ilimitado", momento onde o lugar e a função da mãe inscrevem-se neste psiquismo, assumindo seu caráter inaugural. A partir do estabelecimento gradual de uma discriminação eu/objeto, mas ainda dentro de uma relação dual, sobrepõe-se uma nova demarcação neste terreno relacional materno, onde a criança depara-se com algo de condicional imposto pelo objeto, ou seja, a vivência subjetiva do "amor limitado" característico do jogo relacional próprio da organização anal . Sabemos que na economia psíquica a renúncia de modos relacionais compatíveis às vivências de satisfação não se estabelece impunemente, neste sentido, testemunhos deste desafeto são encontrados nas rebeldias próprias deste período, no ódio dirigido ao objeto que esta nova condição desencadeia, no confronto potencializado na medição de força entre ambos, configurando alguns dos conflitos deste momento da história do sujeito, deixando aí as suas marcas.

A duros golpes o aparelho psíquico diferencia-se alcançando maior complexidade abrindo espaço para o princípio de realidade, procurando amortecer estes impactos, permanecendo em conseqüência algumas cicatrizes e feridas dificultando a reconstituição ilesa do tecido narcísico. 
A saída desta relação dual (sustentada pela figura materna) não é menos dramática quando a criança se vê lançada na triangularidade, no social e na dura constatação do(s) outro(s), agora rival, disputando o campo amoroso com o objeto. A organização fálica, onde se desenvolve a trama edípica coloca o sujeito neste espinhoso terreno. Do ponto de vista freudiano o pai entra neste ponto, entre lágrimas e beijos, encaminhando-se ao longo da vida nas situações reeditadas no mundo.

Sabemos que cada etapa das organizações libidinais permanece nas subseqüentes, mais precisamente podemos dizer que ela é remanejada e ao mesmo tempo continua presente; a existência das neuroses e das psicoses testemunha os percalços consideráveis nesta trajetória. (Mezan, 1985)

Os conceitos de narcisismo e identificação são centrais dentro deste corpo teórico e permitem-nos circunscrever o terreno para estabelecermos uma articulação com o objetivo deste estudo, ou seja, a leitura dos aspectos psicodinâmicos sobre o lugar do pai nas manifestações sintomáticas observadas na clínica infantil. Seguiremos na direção cronológica do surgimento destas elaborações conceituais.

\subsubsection{Do narcisismo dos pais à constituição do sujeito}

O termo narcisismo - amor que se tem pela imagem de si mesmo - surge na obra de Freud a partir de 1910, numa nota acrescentada nos “Tres Ensayos Para Una Teoria Sexual” para descrever a escolha de objetos nos homossexuais: “... toman a sí mismos como fin sexual; esto es, buscan, partiendo de una posición narcisista, hombres jóvenes y semejantes a su propia persona, a los que quieren amar como la madre los amó a ellos.”(p.1178)

É neste ensaio que Freud elabora grande parte de sua teoria sobre o papel da pulsão sexual no conflito psíquico, onde desenvolve a idéia de que a sexualidade não é algo único mas sim um composto de pulsões parciais perversas presentes na infância, definindo-a como sexualidade infantil perverso-polimorfa, centralizando neste ponto a etiologia das neuroses e das perversões.

Também em seu ensaio "Un Recuerdo Infantil De Leonardo De Vinci” (1910), ainda neste mesmo período, Freud refere-se à intensa fixação à mãe, nos homossexuais, mencionando novamente, a escolha de objeto narcísica. No caso Schreber em 1911, o narcisismo é retomado referindo-se a uma fase na evolução sexual intermediária entre o auto-erotismo e a escolha de objeto, embora em 
momentos posteriores a distinção entre auto-erotismo e narcisismo passe a ser suprimida.

Mas foi em 1914, em "Introduccion Al Narcisismo”, que o termo adquiriu um valor de conceito. É neste momento em plena controvérsia com Jung, o qual recusava a função determinante da sexualidade infantil, que Freud com suas articulações teóricas cria condições para explicar com a teoria da libido os quadros regressivos, as psicoses - a demência precoce (Krapelin), ou esquizofrenia (Bleuler) - situando o narcisismo não como uma perversão, mas sim, como "el complemento libidinoso del egoísmo del instinto de conservación; egoísmo que atribuímos justificadamente, en cierta medida a todo ser vivo”, surgindo então a idéia de um narcisismo primário.(p.2017)

$\mathrm{O}$ autor ressalta aqui, o fenômeno libidinal das psicoses onde descreve o processo de desinvestimento do objeto e a conseqüente convergência da libido para o sujeito. Assim, com a afirmação de que na doença mental o sujeito dedica a si mesmo como objeto sexual único, toda a libido que os homens dirigem para o meio e objetos externos, o conflito psíquico se reorganiza em torno do eixo "libido do eu"“libido do objeto”, em busca de um delicado equilíbrio. Deste modo, a megalomania, a doença orgânica, a hipocondria, e a própria vida amorosa, podem ser compreendidos a partir deste novo ângulo. A observação das crianças, bem como a dos povos primitivos, ambos caracterizados por sua crença na magia das palavras e na onipotência do pensamento, permitem-lhe estabelecer a confirmação destas idéias.

O que se postula aqui é um eu depositário e reoganizador da libido autoerótica, um eu, objeto das pulsões. Para que este eu se constitua é necessário os investimentos derivados do narcisismo dos pais, o “outro narcisizante”. Este super investimento onde o filho passa a ocupar este lugar central, lugar de encantamento e perfeição desafiando até mesmo as leis da natureza, a própria finitude, onde a criança para os pais constitui-se em “His Majesty the baby”, sinaliza antes de mais nada o narcisismo dos pais, cuja nova versão no filho será conceituada de eu ideal “eu da onipotência do narcisismo infantil, eu fundido com o id e com a onipotência da mãe”. (Miguelez, 1997) 
A partir desta conceituação, Freud pergunta-se sobre o destino desta libido do eu, portanto de origem narcísica, entendendo que uma parte se desloca para os objetos, mas a outra desempenha importante papel no recalque. É na formação de um ideal que esta condição do recalcamento se manifesta, é numa espécie de negociação que o aparelho psíquico "renuncia” a uma satisfação outrora gozada. “Aquello que proyeta ante sí como su ideal es la sustitución del perdido narcisismo de su niñez, en el cual era él mismo, su propio ideal”.( p.2028)

Assim, Freud refere-se ao ideal do eu que ficará circunscrito, mais tarde, ao denominado supereu, exercendo as suas funções com a consciência moral e a autoobservação, como uma expressão que simultaneamente designa o substituto do narcisismo perdido da infância e o produto da identificação com as figuras parentais e seus substitutos sociais.

Freud neste texto circunscreve o narcisismo na constituição da subjetividade: “Una parte de la autoestima es primaria: el residuo del narcisismo infantil; otra procede de la omnipotencia confirmada por la experiencia (del cumplimiento del ideal); e una tercera, de la satisfacción de la libido del objeto" (p.2032)

Ao abordarmos o conceito de narcisismo e portanto a organização do conflito psíquico em torno do eixo "libido do eu”, "libido do objeto”, remetemo-nos a um campo de amplas discussões e controvérsias de acordo com as diferentes escolas e suas correspondentes leituras. Dessa forma, o conceito de narcisismo secundário - retorno ao ego da libido retirada dos seus investimentos objetais, levanta menos dificuldade do que o de narcisismo primário - estado em que a criança investe toda a sua libido em si mesma. Trata-se da questão do narcisismo entendida dentro de uma definição hipotética da libido infantil enquanto momento da estruturação do psiquismo, mal compreendido algumas vezes, como um período vivido dentro de uma pressuposta anobjetalidade, na medida em que na segunda tópica Freud passa a suprimir a distinção entre o auto-erotismo e o narcisismo, situando este narcisismo primário como um primeiro estado de vida anterior até à constituição de um ego.

Dentro desta leitura aqui proposta, entendemos que Freud situa a presença do “outro" como de valor constitutivo para o sujeito, mesmo quando retoma posteriormente o narcisismo conceituando-o como este momento precoce do desenvolvimento do eu, indicando como auto-erótico tal modo de satisfação das 
pulsões (correspondente a atividade sexual da fase narcísica da organização libidinal). Não podemos esquecer que para Freud, a satisfação estará sempre ligada à imagem do objeto que a proporcionou - vivência de satisfação. Esta vivência está contextualizada no período de “desamparo originário” do bebê humano, aspecto que situa as figuras parentais como centrais na constituição do psiquismo. (Miguelez,1997, p.7-9)

É nesta dialética eu/outro, que poderemos passar ao campo elaborado sob o conceito de identificação, de valor constitutivo para o sujeito.

\subsubsection{Identificação: campo de sustentação do psiquismo}

Desde o início de sua obra, a propósito dos sintomas histéricos, Freud refere-se ao conceito de identificação, entendido como um "processo psicológico, pelo qual um indivíduo assimila um aspecto, uma propriedade, um atributo do outro e se transforma, total ou parcialmente, segundo o modelo dessa pessoa.” (Laplanche, p.295)

Na sua correspondência mantida com Fliess, especificamente numa carta de 1896, ao mencionar a análise de algumas fobias, especificamente da agorafobia nas mulheres, refere-se ao mecanismo do recalque, relacionando a um elemento comum que permanece no inconsciente, ou seja o fantasma (fantasia); assim o agoráfobo identifica-se inconscientemente com uma "mulher de rua” e o seu sintoma é uma defesa contra esta identificação e contra o desejo sexual que ela supõe, apontando para um sentimento de ciúme das prostitutas e de identificação com elas, concebendo neste período este mecanismo como o desejo recalcado de agir ou ser como alguém. Ainda em 1897, Freud evoca em sua correspondência, dentro do contexto de questionamento da sua Teoria da Sedução, a pluralidade das pessoas psíquicas, situando no processo de identificação esta ordem de manifestação subjetiva, observando desde o início que podem coexistir várias identificações.

O conceito de identificação começa a receber um tratamento teórico a partir dos estudos e escritos sobre "La Interpretacion De Los Sueños", tratando no capítulo VI sobre a figurabilidade e observando que a semelhança é a única relação lógica preservada no sonho, sendo expressa freqüentemente através do mecanismo de condensação.(Roudinesco, p.363-364) 
Observamos uma preocupação de Freud em explicitar a chamada imitação histérica (contágio mental), já conhecida de longa data, referindo-se a existência de um elemento inconsciente comum às pessoas em causa, as quais não se constituem em objeto da pulsão sexual. Na identificação histérica, por deslocamento será noutro ponto em que irá produzir-se a identificação, assim a filha poderá adquirir o mesmo sintoma patológico da mãe, significando por um lado o desejo hostil de substituí-la ao lado do pai, mas expressando também a culpa, experimentando os mesmos sofrimentos.

Entre outros aspectos, o tema da identificação abrange duas características fundamentais: por um lado, o de ser um processo fundante e estruturante do aparato psíquico que se estende pela vida afora, por outro lado, o de ser um complexo e poderoso mecanismo de defesa que pode se colocar a serviço da elaboração das renúncias de escolhas amorosas que fatalmente os indivíduos devem sofrer no seu processo de desenvolvimento. Apoiados em ambas conduziremos o raciocínio clínico deste estudo na ilustração dos casos apresentados.

Do ponto de vista teórico, a sistematização deste tema ocorre a partir de 1912, em “Totem e Tabu” ao tratar da incorporação oral (o modelo canibalesco) que abrange três significações, respectivamente, a de obter um prazer fazendo penetrar um objeto em si, de destruir esse objeto e de assimilar as qualidades desse objeto conservando-o dentro de si, circunscrevendo a incorporação como a matriz da introjeção e da identificação. (Laplanche, 1983)

Em 1914, no texto sobre o narcisismo, Freud trata da escolha de objeto narcísica - onde o objeto é escolhido segundo o modelo da própria pessoa - e da escolha de objeto por apoio estabelecendo a dialética ligada à identificação onde o sujeito se constitui com base no modelo parental ou no dos substitutos dos pais. Lembremo-nos no entanto, que mesmo esta escolha por apoio, comporta em sua origem toda a matriz narcísica resultante das primeiras relações.

No texto "Duelo Y Melancolia" (1917), Freud ressalta o papel da identificação na melancolia, destacando a identificação do sujeito com o objeto perdido, por regressão, à relação de objeto característica da fase oral, “...no vacilaríamos en integrar entre las características de la melancolía la regresión de la carga de objeto a la fase oral de la libido, perteneciente aún al narcisismo.” (p.2095) 
Encontramos a retomada deste posicionamento teórico acompanhando as mudanças sobre o modelo edípico, onde os efeitos sobre a estruturação do indivíduo são descritos em forma de identificação, ou seja, o abandono do investimento parental se dá via identificações, elaborando-se uma estrutura complexa onde pai e mãe são cada um por sua vez, objeto de amor e rivalidade enfatizando o elemento ambivalente em relação ao objeto.

Com a elaboração da segunda tópica freudiana, a partir de 1920, a importância metapsicológica do conceito de identificação situa-se no cerne da teoria psicanalítica. Já em "Psicologia De Las Masas Y Analisis Del Yo” (1921), especificamente no sétimo capítulo - “La Identificacion”, Freud propõe-se a trabalhar detalhadamente este tema, estabelecendo a diferenciação entre a identificação com o objeto e a escolha do mesmo como objeto sexual, ressaltando esta diferença da seguinte maneira:

\begin{abstract}
"No es difícil expresar en una fórmula esta diferencia entre la identificación con el padre y la elección del mismo como objeto sexual. En el primer caso, el padre es lo que se quisiera ser; en el segundo, lo que se quisiera tener. La diferencia está, pués, en que el factor interessado sea el sujeto o el objeto del yo. Por este motivo, la identificación es siempre posible antes de toda elección de objeto". (p. 2585)
\end{abstract}

Neste capítulo Freud faz ainda uma exposição completa deste conceito, especificando três modalidades: primeiramente a identificação como forma originária de um laço afetivo - identificação primária; uma segunda modalidade que a situa como substituto regressivo de uma escolha de objeto abandonada, sendo exemplificada por Freud com o caso Dora, especificamente com o fato da identificação poder incidir sobre um sintoma da pessoa amada, assim Dora imitava a tosse do pai, mecanismo pelo qual “...la identificación há ocupado el lugar de la elección de objeto, transformándose ésta, por regresión, en una identificación” (p. 2586). A terceira modalidade corresponde à identificação histérica onde se ressalta um elemento inconsciente comum, independente de qualquer investimento libidinal do objeto. 
Com a elaboração da segunda tópica do aparelho psíquico, a partir de 1923 ao escrever "El Yo Y El Ello" concebe a constituição das estruturas psíquicas não mais como sistemas em que se inscrevem imagens, recordações, mas como produto das identificações, “como resquícios em diversas modalidades das relações de objeto”. (Laplanche, 1983, p.297)

Neste percurso identificatório do sujeito dentro do pensamento freudiano, podemos situar as primeiras identificações que serão a matéria prima para a construção do ego, como diretas, imediatas, produzindo-se ainda quando não está o eu agindo como mediador entre o Isso e o mundo externo, uma vez que não existe claramente estabelecido um limite entre ambos: Isso e mundo exterior são a mesma coisa, toda representação alucinada vai constituir-se imediatamente em uma identificação. Nesta identificação primária temos um mecanismo que não é subjacente à relação entre o sujeito e o objeto (ainda não destacados) mas constitui-se por si nesta relação, baseia-se no modelo da oralidade, na incorporação que é a forma mais primitiva de relação objetal que se caracteriza pela ambivalência, envolvendo tanto o amor e conservação, como a destruição do objeto. (in: Blanes,1989)

Até este momento, referimo-nos ao eu produzido desde as projeções narcísicas parentais constituindo o eu ideal, onipotente, perfeito e narcísico. Essas identificações primárias serão resignificadas a partir de identificações posteriores à eleição de objeto, responsáveis pela configuração da personalidade do sujeito, servindo, portanto, de base a processos ulteriores de identificações mais elaboradas onde o sujeito desejará não ser um com o objeto, mas chegar a ser no futuro semelhante a ele, em um ou vários de seus aspectos (ideal do eu).

Num processo identificatório seguinte ao que descrevemos primariamente, especificamente quando o eu começa a destacar-se do Isso, portanto, no início da distinção eu /não eu, os investimentos de objeto começam a diferenciar-se das identificações. Assim as cargas de objeto partem do Isso, na sua demanda enquanto aspirações eróticas, sendo por sua vez reconhecidas pelo eu que as tolera ou delas se defende através do recalcamento. Neste momento inaugural da segunda tópica, Freud ressalta que: 
“... los efectos de las primeras identificaciones, realizadas en la más temprana edad, son siempre generales y duraderos. Esto nos lheva a la gênesis del ideal del yo, pues detrás de él se oculta la primera y más importante identificación del individuo, o sea, la identificación con el padre.” (p.2711-2712)

Esta afirmação vem acompanhada de uma nota onde ele opta por maior prudência ao dizer “con los padres” .

Deste modo, a criança obrigada à renúncia de seus objetos eróticos, o faz com a condição de identificar-se com eles e desta forma conservá-los, embora modificados. Ao falarmos em investimento de objeto e identificação para a criança introduzimos a problemática do complexo de Édipo, pois é justamente neste momento que se produzem identificações secundárias à escolha de objeto que irão “finalizar” por assim dizer, a organização das estruturas intrapsíquicas surgidas a partir das identificações primárias.

Assim, no caso de uma menina, quando sua escolha objetal recai sobre o pai é anaclítica ou por apoio, enquanto seu desejo de possuir a mãe implica em uma forma narcisista de escolha de objeto; no caso do menino, desde a perspectiva do Édipo positivo, sua escolha objetal é por apoio quando recai sobre a mãe, já na vertente edípica negativa, elege ao pai como objeto, pressupondo narcisicamente uma identificação com a mãe.

Aproximamo-nos do desfecho dessa situação implicando para a criança que tanto o pai, quanto a mãe sejam perdidos como objetos sexuais, passando as cargas de objeto abandonadas a serem substituídas por identificações com estes objetos primários de escolha, tanto com o pai como com a mãe, combinando-se as quatro tendências integrantes do complexo de Édipo completo. Deste modo, nas palavras de Freud:

“...La identificación con el padre conservará el objeto materno del complejo positivo y sustituirá simultaneamente al objeto paterno del complejo invertido. Lo mismo sucederá, mutatis mutandis, con la identificación con la madre. En la distinta intensidad de tales identificaciones se reflejará la desigualdad de las dos disposiciones sexuales”. 
Freud ressalta neste momento a enérgica formação reativa contra as escolhas de objeto, que estão na base da constituição do supereu, concluindo:

“... el super-yo conservará el carácter del padre, y cuanto mayores fueron la intensidad del complejo de Édipo y la rapidez de su represión..., más severamente reinará después sobre el yo como conciencia moral, o quizá como sentimiento inconsciente de culpabilidad”. (p.2713-2715)

A condição que se propõe possibilita para Freud situar o núcleo do supereu (herdeiro do complexo de Édipo) em seu artigo de 1924 "La Disolucion Del Complejo De Édipo” a partir da autoridade do pai ou dos pais introjetada no eu, perpetuando a proibição do incesto e dando garantias ao eu contra o retorno das cargas de objetos libidinosas. (p.2750)

Observamos desta maneira que progressivamente o mecanismo de identificação vai adquirindo um valor central na teoria freudiana passando a configurar-se como a operação pela qual o indivíduo humano se constitui, assim organizando-se a personalidade e diferenciando-se conseqüentemente por uma série de identificações.

Freud ao tratar do supereu ressalta nos processos identificatórios a figura paterna, lugar onde é projetado o essencial do narcisismo "perdido" da infância, decorrendo daí a sua idealização e entendendo que apesar de todas as influências ulteriores as quais o eu sofre:

“... conserva, sin embargo, durante toda la vida el carácter que le imprimió su gênesis del complejo paterno, o sea la capacidad de oponerse al yo y dominarlo... del mismo modo que el niño se hallaba sometido a sus padres y obligado a obedecerlos, se somete el yo al imperativo categórico de su super-yo”.(p.2721)

Nesta direção, pretendemos focalizar na teoria freudiana o complexo paterno na dimensão constitutiva do psiquismo na criança. 


\subsection{Uma revisão sobre o lugar do pai na teoria freudiana - o complexo paterno}

"Aquello que has heredado de tus padres, conquístalo para poseerlo.”6

(Goethe)

Ter como proposta uma revisão sobre o lugar do pai na teoria freudiana, implica em idas e vindas em busca de articulações dos conceitos elaborados por Freud, em diferentes momentos de sua obra. Entendemos que estes conceitos foram construídos por ele progressivamente num trabalho árduo e acompanhado de inúmeros impasses e contratempos. Assim, se faz necessária uma cuidadosa e constante observação dos diferentes momentos da teorização do inconsciente, que na literatura psicanalítica por vezes são sobrepostos de forma desordenada. Seguiremos a ordem cronológica para orientarmo-nos dentro desta perspectiva.(Gomes,1998)

Inicialmente, buscaremos através do surgimento e do percurso dos conceitos centrais para esta temática paterna, entender a sua configuração e importância dentro da obra freudiana, visando estabelecer articulações que nos instrumentem no rastreamento do lugar paterno - “complexo paterno” - e de sua importância do ponto de vista metapsicológico. Considerando que na terminologia freudiana, o conceito de complexo é associado apenas a dois conjuntos de representações inconscientes no campo psíquico, respectivamente o complexo de Édipo e o complexo de castração, ambos correlatos e articuladores da dimensão ambivalente com o pai, focalizaremos esta temática a partir destes eixos referenciais para destacarmos com maior abrangência os aspectos dinâmicos que aí se originam.

Com este intuito, abordaremos inicialmente a noção de complexo de Édipo - "conjunto organizado de desejos amorosos e hostis que a criança experimenta relativamente aos pais” - situando o seu surgimento, suas modificações e diferentes versões. (Laplanche e Pontalis, 1983, p.116)

\footnotetext{
${ }^{6}$ Goethe, J.W., Fausto. (Apud) Freud, S., (1912-13). “Totem y Tabu”. In: Obras completas. Trad.Luis Lopez-Ballesteros y de Torres. 4.ed. Madrid, Biblioteca Nueva, 1981.v.2, p.1849.
} 


\subsubsection{A familiaridade com o Édipo: o paradigma do destino humano}

Encontramos nos primeiros momentos do pensamento freudiano, propriamente com a sua teorização sobre a idéia de trauma, pelo menos dois pontos fundamentais, que se diferenciam da teoria catártica de Breuer: o trauma será sempre de natureza sexual, ainda que no sintoma não se encontre qualquer indício e terá ocorrido na infância, sendo esquecido - lembranças desagradáveis exiladas no “inconsciente”, neste momento concebido como “depósito de traumas” - até que a puberdade o ressuscite através de uma sexualidade recentemente despertada.

A partir de 1893 Freud começa a mencionar a sedução enquanto descoberta clínica, baseado no relato das pacientes no decorrer do tratamento, mas é entre 1895 e 1897 propriamente que a “Teoria da Sedução" é elaborada e assume maior importância teórica, na medida em que atribui às cenas de sedução um valor traumático e determinante na etiologia das neuroses. Embora a teoria da Sedução tenha sido ulteriormente abandonada por Freud, sua importância teórica está no princípio de uma tentativa de explicar na sua origem o mecanismo do recalcamento.

As diferentes queixas, expressões de sofrimento de seus pacientes, onde o “elemento sexual está cuidadosamente disfarçado”, levam Freud para um trabalho classificatório e posteriormente etiológico, do ponto de vista da psicopatologia. Assim temos a histeria (inicialmente atribuída somente às mulheres) depois a identificação da neurose obsessiva e logo a fobia - oficialmente circunscrita como histeria de angústia.(Goldgrub,1989 p.16-17)

Um comentário de Freud, em seu texto “Autobiografia” (1925) permite-nos justificar o motivo de partirmos deste período inicial da psicanálise para tratarmos do surgimento da conceituação edípica. Freud nos diz que antes de ter aprofundado seu estudo sobre a sexualidade infantil, chegou a sucumbir durante algum tempo em um erro que poderia ter-lhe sido fatal, pois acreditava nos relatos de suas pacientes, cujo conteúdo referia-se à infância delas, nas quais teriam sido seduzidas por algum adulto. Nas mulheres o papel de corruptor aparecia atribuído freqüentemente ao pai. Freud acreditava frente tais acontecimentos ter encontrado a causa das neuroses posteriores. Mas ao constatar que estas cenas de sedução relatadas não haviam de fato ocorrido, pois correspondiam a fantasias, foi obrigado a concluir definitivamente que para a neurose era mais importante a realidade psíquica (fantasia) que propriamente os fatos. Neste momento afirma: "fue éste mi primer 
contacto con el complejo de Edipo, que después habia de adquirir tan extraordinaria importancia para el psicoanálisis; pero entonces no llegué a vislumbrarlo debajo de su fantástico disfraz”. (Freud, p.2777) ${ }^{7}$

Freud depara-se neste ponto com a seguinte passagem: do relato da sedução da filha pelo pai ao seu amor edipiano pelo pai.

O abandono por Freud da teoria da Sedução em 1897 constitui-se num momento inaugural da teoria psicanalítica e na colocação em primeiro plano das noções de fantasia inconsciente (ou fantasma), de realidade psíquica, de sexualidade infantil. (Laplanche e Pontalis, 1983, p.612)

Destaca-se a partir de então, que cada um recria a sua própria infância, onde a fantasia adquire do ponto de vista objetivo o estatuto de ficção e do ponto de vista subjetivo,constitui uma verdade (a verdade do sujeito). Podemos dizer que o empenho de Freud ao longo de suas reflexões está justamente na tentativa de explicar a relativa organização da vida fantasmática do indivíduo.

Portanto, o mito de Édipo surge para Freud no exato momento do surgimento da psicanálise, consecutivo ao abandono da teoria da sedução -1897adquirindo posteriormente um lugar soberano dentro de sua obra.

Em sua publicação “ La Interpretacion de los Sueños” (1900), o complexo de Édipo aflora pela primeira vez sem no entanto estar imbuído ainda da importância crucial que este conceito viria a ter para a psicanálise. Assim comenta Freud no capítulo que trata do conteúdo e origem dos sonhos:

"Pero si este infantil deseo de la muerte de los hermanos queda explicado por el egoísmo del niño, que no ve em ellos sino competidores, cómo explicar igual optación com respecto a los padres, que significan para él uma inagotable fuente de amor y cuya conservación debiera desear, aum por motivos egoístas, siendo como son los que cuidan de satisfacer sus necesidades?”(p.503)

\footnotetext{
7 Este comentário, segundo Strachey, já em 1897 consta na carta 71 de Freud dirigida a Fliess no decorrer de sua auto-análise, que o leva a reconhecer em si o amor pela mãe e, para com o pai, um ciúme em conflito com a afeição que lhe dedica, resultando então, que a questão do pai para Freud se inscreve na elaboração de suas representações pessoais; reconhecendo neste mesmo período ainda, a universalidade do mito grego Édipo-Rei.
} 
Freud identifica que os sonhos deste gênero são freqüentemente no homem, dirigido ao pai e na mulher, em relação à mãe. Anima-se a buscar sua explicação em um fator de alcance universal, concluindo:

“En términos generales, diríamos, pues, que sucede como si desde edad muy temprana, surgiese una preferencia sexual; esto es, como si el niño viviese em el padre y la niña em la madre, rivales de su amor, cuya desaparición no pudiese serles sino ventajosa”. ( p.503)

Em 1905, nos “Tres Ensayos Para Una Teoria Sexual”, momento onde Freud abandona uma concepção sexológica da sexualidade, em favor de uma abordagem psíquica do sexual, fazendo da libido o determinante fundamental do psiquismo humano, agregam-se conceitos que abririam o caminho para compor a importância da trama edípica na constituição da subjetividade, assim sendo, o conceito de pulsão que permite apreender os desvios em relação ao objeto sexual possibilitando para Freud, analisar as perversões e reintegrá-las no quadro geral de um funcionamento pulsional organizado em torno de um conjunto de zonas erógenas. É neste estudo que se destaca o componente central da organização da sexualidade infantil, denominado “disposição perverso-polimorfa”, sendo as atividades infantis ( tipos de sucção, as brincadeiras com o corpo e com as fezes...) fontes de prazer e de auto-erotismo, não conhecendo lei nem proibição.

Com as "teorias sexuais” fabricadas pelas crianças a propósito de sua origem, para resolver o enigma da copulação, do nascimento e da diferença sexual, Freud dá voz a um verdadeiro testemunho desta forma ilimitada de satisfação com todos os objetos e alvos possíveis. A teoria da cloaca, segundo a qual os bebês vêm ao mundo pelo reto e são equivalentes as fezes, da mesma forma, mas, com sua devida variação, o parto através do umbigo, e a teoria do caráter sádico-anal do coito parental, são algumas entre as diversas formulações infantis aqui consideradas.

A constatação de que não só o corpo da criança, mas a sua mente está profundamente interessada nas ligações afetivas que se desenvolvem a partir da “novela familiar” , em meio a um cenário de sedução, rivalidade, ciúmes, amor, ódio, e de que, por outro lado, os próprios pais participam deste enredo com suas preferências, rejeições, na valorização dos filhos conforme o sexo, levam-no a 
compor a trama edípica com toda a sua abrangência na estruturação da personalidade, estabelecendo neste sentido, que é principalmente na ordem do desejo que a sorte será lançada. Em outras palavras, justamente neste inconsciente disfarçado de destino...

Segundo a tese canônica, o complexo de Édipo está ligado à fase fálica da sexualidade infantil, vivido no seu período máximo entre os três e cinco anos, o seu declínio marca a entrada no período de latência. É justamente na puberdade, o período em que sofre uma revivescência e é superado com maior ou menor êxito num tipo especial de escolha de objeto.(Laplanche, p.116)

Entre o período de 1905 e 1923, houve quatro edições dos Três Ensaios, havendo Freud introduzido modificações à medida que ia aperfeiçoando sua teoria da libido, organizando o dualismo pulsional e desenvolvendo sua concepção do narcisismo. Assim, é numa revisão posterior que o complexo de Édipo é relacionado com a fase fálica, sendo este elemento tardiamente agregado de acordo com a evolução de sua teoria.

Ainda em 1908, num ensaio chamado “Teorías Sexuales Infantiles”, Freud descreve a atividade intelectual da criança, desencadeada pelo seu temor de que um rival (um novo irmão) venha a usurpar seu lugar. Embora não haja uma menção direta à situação triangular com os pais, a presença sinalizada de um desejo de exclusividade cuja rivalidade se daria entre os iguais, os irmãos, mais aceitável portanto do que com a figura paterna, anuncia este novo cenário protagonizado pela criança e o casal parental. (Goldgrub,1989, p.22-23)

Neste mesmo período Freud descreve pela primeira vez o complexo de castração, sendo referido à teoria sexual infantil que atribuindo um pênis a todos os seres humanos, somente pela castração pode explicar a diferença anatômica dos sexos, prefigurando-se já neste momento a sua significação narcísica. (Laplanche, p.111)

Nas “Cinco Conferencias del Psicoanalisis”, pronunciadas em 1909, mas redigidas em 1910, especificamente na " $4^{a}$ Conferencia", constatamos através da seguinte passagem, a familiaridade de Freud com este conceito: 
El padre prefiere em general a la hija, y la madre al hijo, y el niño reacciona a ello com el deseo, si es varón, de hallarse em el puesto de su padre, o en el de su madre si es hembra. Los sentimientos despertados en estas relaciones entre padres e hijos y en las de los hermanos entre si no son sólo de naturaleza tierna y positiva, sino también negativos y hostiles. El complejo que de este modo se forma está destinado a una pronta represión; pero ejerce luego, desde lo inconsciente, una magna y duradera influencia, y debemos manifestar nuestra sospecha de que, con sus ramificaciones, constituye el complejo nódulo de todas y cada una delas neurosis, hallándonos preparados a encontrarlo con no menos eficacia en otros dominios de la vida psíquica. El mito del rey Edipo, que mata a su padre y toma a su madre por mujer, es una exposición aún muy poco disfrazada del deseo infantil ante el qual se alzan después, rechazándolo, las barreras del incesto. El Hamlet shakespeariano reposa sobre la misma base, aunque más encubierta, del complejo del incesto.(p.1558)

Embora a familiaridade com o conceito complexo de Édipo tenha já se manifestado nestes textos a que nos remetemos, o primeiro emprego publicado do termo por Freud, surge de acordo com o editor inglês das obras completas, Strachey, em 1910, num artigo, "Sobre un tipo especial de la elección de objeto en el hombre”, onde encontramos a seguinte passagem: “... Comienza, pues, a desear a la madre, en el nuevo sentido descubierto, y a odiar de nuevo al padre, como a um rival que estorba el cumplimiento de tal deseo. En nuestra terminología decimos que el sujeto queda dominado por el complejo de Édipo".(p.1628-1629)

Partindo deste princípio dos diferentes momentos da obra freudiana, o Édipo não será o mesmo, conforme a data do texto em que comparece. Caminhamos até este momento dentro do que poderíamos chamar de um primeiro modelo da conceituação edípica, ou seja, sob a sua forma simples e positiva que justamente caracteriza como este complexo foi descoberto, tal como se apresenta na história do Édipo-rei: desejo da morte do rival que é a personagem do mesmo sexo e desejo sexual da personagem do sexo oposto.

Encontramos na tragédia de Sófocles, a transformação da vida do rei de Tebas num paradigma do destino humano, apoiando-se Freud nesta trama para 
relacionar o destino com uma determinação psíquica vinda do inconsciente. Remetemo-nos ao mito:

Na mitologia grega, Édipo é o filho de Laio e Jocasta. Para evitar o destino anunciado pelo oráculo de Apolo, que lhe previra que ele seria morto pelo filho, Laio entrega seu menino recémnascido a um criado, para que ele o abandone no monte Citéron, depois de lhe transpassar os pés com um prego. Em vez de obedecer, o criado confia o menino a um pastor de ovelhas, que em seguida o entrega a Pólibo, rei de Corinto, e à mulher deste, Merope, que não têm descendentes. Eles lhe dão o nome de Édipo (oidipos: pés inchados) e o criam como seu filho.

Édipo cresce e ouve rumores que dizem que ele não seria filho de seus pais. Por isso, dirige-se a Delfos para consultar o oráculo, que de pronto lhe responde que ele matará o pai e desposará a mãe. Para escapar a essa previsão, Édipo viaja. Na estrada para Tebas, cruza por acaso com Laio, a quem não conhece. Os dois homens brigam e Édipo o mata. Nesta época, Tebas vinha sendo aterrorizada pela Esfinge, monstro feminino alado e dotado de garras, que mata todos aqueles que não decifram o enigma que ela propõe sobre a essência do homem: “Quem é aquele que anda sobre quatro pés, depois sobre dois e, depois sobre três?” Édipo dá a resposta certa e a Esfinge se mata. Como recompensa, Creonte, o regente de Tebas, dá-lhe por esposa sua irmã, Jocasta, com quem ele tem dois filhos, Eteoclés e Polinices, e duas filhas, Antígona e Ismene.

Os anos passam. Um dia, a peste e a fome se abatem sobre Tebas. O oráculo declara que os flagelos desaparecerão quando o assassino de Laio tiver sido expulso da cidade. Édipo pede então a todos que se manifestem. Tirésias, o adivinho cego, conhece a verdade, mas se recusa a falar. Por fim, Édipo é informado de seu destino por um mensageiro de Corinto que lhe anuncia a morte de Pólibo e lhe conta como ele próprio, no passado, havia recolhido um menino das mãos do pastor para entregá-lo ao rei. Ao saber da verdade, Jocasta se enforca. Édipo vaza os próprios olhos e em seguida se exila em Colono com Antígona, enquanto Creonte retoma o poder. (in Roudinesco, 1998, p.166-167) 
Em Édipo rei, Sófocles adapta apenas uma parte do mito (a que se relaciona com as origens de Tebas) e a faz verter-se no molde da tragédia.

Starobinski (1967) ressalta que o Édipo rei - mito da antiguidade clássica era para Freud a tragédia da revelação, simbolizando como herói antigo, o universal do inconsciente, mascarado de destino. Já Hamlet, enquanto herói moderno originário do drama shakespeariano, nos remeteria ao nascimento de uma subjetividade culpada, representante, portanto, do drama do recalcamento. Poder-seia, ainda, agregar uma terceira vertente (1927), resultante do romance de Dostoievski, “Os irmãos Karamazov" 8 onde entra em cena a própria pulsão assassina, especificamente, o caráter universal do desejo parricida, onde cada um dos três irmãos confrontam-se com o desejo de matar realmente o pai.(in: Roudinesco, 1998, p.167)

Os estudos de Goldgrub (1989) referem-se também a diferentes momentos em que este conceito pode ser lido, respectivamente, num primeiro momento, este autor situa o complexo de Édipo empírico, que corresponde a esta formulação inicial de Freud, cuja argumentação não comportava a intensa ambivalência afetiva infantil, obrigando Freud a dirigir para outro lugar a sua busca na origem destas emoções contraditórias - amor, ódio, ciúmes, admiração. É justamente num Édipo alicerçado no terreno das ficções, chamado por ele de estrutural que comporta os conceitos de fantasia e sexualidade infantil culminando com a teorização sobre as fantasias originárias e as teorias sexuais infantis, que Freud alcança maior abrangência no contexto da afetividade dirigida às figuras parentais.

Neste chamado primeiro modelo fica claramente delineado, como ponto central, a importância dos pais enquanto influência fundamental e determinante com relação ao futuro do filho. Assim, para sobreviver, toda criança deverá contar com uma figura em cujo desejo ocupe um lugar fundamental e que, por outro lado, estará condenada a perder esse lugar, por injunção da mesma figura, na medida em que for percorrendo o caminho pelo qual todo ser humano assume o próprio desejo, tornando-se um sujeito. Esta perda do lugar central à figura materna é atribuída a um rival usurpador, real ou imaginário.(Goldgrub, 1989, p. 27)

8 Fiodor Dostoievski $(1821-1881)$ 


\subsection{2. Édipo: da simplificação para a complexidade de sua abrangência}

Destacaremos o que chamaremos de um segundo modelo do complexo de Édipo, que parte justamente da sua forma negativa ou denominada Édipo invertido, onde Freud sobrepõe à simplificação anterior, a vivência de amor pelo progenitor do mesmo sexo e ódio ciumento ao progenitor do sexo oposto. Dos estudos entre ambas as formas - positiva e negativa - deste complexo que se encontram em graus diversos numa articulação dialética, temos a origem da chamada forma completa do complexo de Édipo, onde diferentes posições são adotadas pelo indivíduo frente a assunção e resolução desta conflitiva. Recorreremos aos textos que conferem sustentação na ampliação deste conceito.

Em 1912, com o livro “Totem y Tabu”, Freud ansiava dar uma explicação global da origem das sociedades e da religião, visando encontrar um fundamento histórico ao mito do Édipo e à proibição do incesto e mostrando que a história individual de cada sujeito não é mais do que a repetição da história da própria humanidade. Criticado pelas suas interpretações equivocadas do ponto de vista da antropologia, em função dos pressupostos de estudos etnológicos da época, que compunham a tradição da antropologia evolucionista do fim do século XIX, “Totem y Tabu” representa, segundo Mezan (1986), o ponto de convergência de todo um período de investigações realizadas até então por Freud, assim:

“... são retomados, elementos da neurose obsessiva (a ambivalência e os tabus), da psicose (projeção e narcisismo), da fobia (o sentido paterno do animal totêmico); as questões colocadas têm como horizonte a função do pai, onipresente nesta temática; e o resultado do trabalho consiste em ancorar o complexo de Édipo não apenas nas fantasias dos neuróticos, mas no ponto de origem da civilização, fundando assim de modo mais amplo e seguro a afirmação de sua universalidade.” (p.322)

O ponto de partida desta obra, está localizado no estudo do totemismo e suas vinculações com a exogamia, desenvolvendo na sua trajetória, um paralelo entre a origem desses costumes e a origem das neuroses, assim como, uma cuidadosa observação sobre a função das proibições e leis que são ordenadoras do sistema de 
relações sociais vigentes na cultura. Trata ainda da origem da religião compreendendo o totemismo como etapa inicial do âmbito das crenças religiosas.

Utiliza como referência para este estudo as tribos dos aborígenes australianos, considerados como um dos grupos mais primitivos, entre os quais encontra-se estabelecido o sistema do totemismo. Este sistema organiza a subdivisão das tribos, de acordo com um totem herdado pelas mesmas, formando grupos menores que correspondem aos clãs; assim, cada clã é representado pelo nome de seu totem, sendo freqüentemente um animal (raramente um vegetal ou fenômeno natural) para o qual se estabelecem regras obedecidas por todo o clã. Com essas regras proíbe-se a destruição desse animal, que não se pode matar nem comer de sua carne, sendo o totem transmitido hereditariamente, tanto por linhagem paterna como materna. A base das relações sociais de cada integrante da tribo está sustentada pela relação que se estabelece com seu totem, com este antepassado do clã, espírito guardião que embora perigoso para os outros, poupa os seus próprios filhos, sendo por sua vez, muito mais importante que qualquer relação consangüínea. (p.17471749)

Freud articula os sistemas do totemismo ao da exogamia focalizando o tema da existência de leis que proíbem relações sexuais entre pessoas do mesmo clã e portanto do mesmo totem, estabelecendo-se um impedimento do casamento entre si. Diante da violação destas proibições fica determinada a penalidade de morte ao infrator.

Em ocasiões específicas ocorrem festas dento do grupo totêmico, cerimônias onde por meio de danças, se dá uma imitação de movimentos e particularidades do totem.

Nestas comunidades observa-se o sistema classificatório de parentesco onde é nomeado "pai”, não apenas o genitor, mas todos os homens com quem a mãe poderia ter casado, estabelecendo-se esta mesma abrangência dos relacionamentos sociais nos termos de parentesco para as palavras “mãe”, “irmão” e “irmã”.

Fica evidente como elemento característico destes povos, o verdadeiro horror ao incesto, mas o significado da restrição da liberdade sexual e da escolha de casamento não se encontra justificada por qualquer razão prática. 
Dentro do pensamento freudiano, abre-se a perspectiva de compreensão deste temor ao incesto, vivida pelos diferentes povos, a partir da relação estabelecida com um traço da vida psíquica infantil, onde a atitude incestuosa com os pais constitui-se como o complexo nuclear da neurose. (p.1757-1758)

Com o intuito de melhor compreender o sentido destas relações, Freud passa a desenvolver o significado do termo tabu: palavra polinésia considerada de difícil tradução pela variação de seus significados, inclusive de caráter oposto, ou seja, comporta o sentido de "sagrado" como também o sentido de "proibido", “impuro". Manifesta-se através de proibições e restrições, abarcando os objetivos mais diversos: de proteger as pessoas importantes da tribo, salvaguardar os fracos do poderoso mana (influência mágica) de chefes e sacerdotes, prevenir contra os perigos decorrentes do manuseio com cadáveres e garantir os principais atos da vida, tais como o nascimento ou atos de "iniciação” e casamento.(p.1759)

Ocorre um alargamento dos respectivos tabus abarcando objetos e situações que tenham entrado em contato com este "campo de força” o qual esses povos acreditam ser inerente ao próprio tabu, portanto há um fator de transmissibilidade (contágio), tanto através de um contato físico como um contato intelectual feito pelo pensamento, sintetizado pelo valor metafórico da expressão “entrar em contato com”. A violação de um tabu atrai os piores castigos, daí a necessidade de evitá-los através de cerimoniais de expiação.

É justamente neste ponto que Freud estabelece, pela similaridade, a relação entre o sistema proibitivo destes povos primitivos e dos neuróticos obsessivos, sintetizando os pontos de coincidência entre ambos: " $1^{\circ}$ La falta de motivación de las prohibiciones; $2^{\circ} \mathrm{Su}$ imposición por uma necessidad interna; $3^{\circ} \mathrm{Su}$ facultad de desplazamiento y contagio, y $4^{\circ}$ La causación de actos ceremoniales y de prescripciones, emanados de las prohibiciones mismas”. (p.1765)

Freud detém-se numa análise da origem da fobia de contato através dos mecanismos observados já na primeira infância onde emergem na criança forças pulsionais, expressas por fortes desejos de tocar (referidos na manipulação dos órgãos genitais), recebendo a proibição das pessoas com quem a criança encontra-se amorosamente ligada (figuras parentais), favorecendo no sentido de que ela aceite esta proibição. Mesmo assim ela não consegue abolir o componente pulsional recalcando o desejo de tocar. Assim, a proibição por um lado e o representante pulsional por outro permanecem presentes tendo como conseqüência por parte do 
sujeito, uma atitude ambivalente para com um objeto determinado. Estabelece-se, desta forma, a relação de ambivalência: o ato de tocar é ao mesmo tempo desejado pela satisfação alcançada, mas é também detestado, pois há uma proibição que bloqueia sua realização. O tabu nasce portanto no terreno de uma ambivalência, se há proibição, se há temor é porque há precisamente o desejo.

A partir desta direção configura-se para Freud a perspectiva da elaboração do mito original, centralizado na figura do pai, em especial, na categoria do pai morto - do assassinato do pai. Esta direção comporta a análise dos sentimentos de ambivalência, a onipotência dos pensamentos (articulada ao narcisismo) e os mecanismos de projeção e deslocamento, presentes tanto nos povos primitivos como característicos da vida mental dos pacientes obsessivos.

Retoma esta analogia na atitude dos primitivos com relação ao seu rei, onde atribui-se a uma pessoa de importância um poder ilimitado com o intuito de descarregar sobre ela a responsabilidade do penoso que sucede à própria pessoa; assim o rei pode ser destronado ou morto porque sobre aquele povo abateu-se uma desgraça. Do mesmo modo, considera Freud o quadro que o paranóico reproduz em seu delírio persecutório que corresponde às relações entre a criança e seu pai:

"El hijo atribuye, en efecto, a su padre uma parecida omnipotencia, y puede comprobarse que su ulterior desconfianza com respecto a èl se halla em proporción directa com el grado de poder que antes le ha atribuído. Cuando um paranóico reconoce a su perseguidor en una de las personas que lê rodean, la promueve com este hecho a la categoría de padre; esto es, la sitúa en condiciones que le permiten hacerle responsable de todas las desgracias imaginarias de que es víctima”.(p.1779)

Assim, este aspecto é encontrado nos tabus relativos aos governantes, assim como aos mortos, inimigos de combate, com quem se adotava práticas muito cruéis, seguidas de um temor supersticioso dos fantasmas dos assassinados, justificando o uso de rituais de purificação e de apaziguamento numa tentativa de compensação aos sentimentos hostis dirigidos aos inimigos, antes de sua morte. Acreditam que suas almas (dos inimigos) se transformam em demônios, daí a necessidade de, através de tabus, gerar uma proteção para os sobreviventes de sua provável hostilidade. 
Encontramos na base da crença desta transformação a expressão dos mecanismos de deslocamento e projeção em que, o sujeito negando a hostilidade latente no seu inconsciente, projeta nos mortos os sentimentos que são seus.

O exame do animismo (teoria que dá vida aos objetos inanimados) e da magia (que torna real aquilo que é pensado) também realizados nesta obra, procuram corresponder à necessidade do homem de controlar os fenômenos da natureza, com o propósito de proteger o indivíduo de seus inimigos e dos diversos perigos, seguindo os princípios de associação de idéias: a semelhança e a contigüidade.

Assim, entre os elementos fundamentais para a compreensão desta obra, podemos reunir: os tabus relacionados ao incesto com o fator das interdições, a ambivalência dos sentimentos dirigida aos mortos, associada com as práticas de sacrifícios e de purificação e por fim, a crença no animismo e na magia que conduz para a onipotência dos pensamentos.

Visando o esclarecimento sobre o surgimento do totemismo que aponta para a origem da condição humana, Freud retoma a idéia do assassinato do pai primevo.

Os casos de zoofobia infantil - o pequeno Hans e Arpad, o homenzinhogalo, em que o animal temido substitui o pai - estabelecem a base para a associação com o fato de que o totem, nas tribos primitivas, é designado como o ancestral mítico do clã.

Retomemos o mito elaborado por Freud ao utilizar a descrição de Darwin (modificada por Atkinson) sobre a teoria da horda primitiva descrita para os gorilas, na passagem do estabelecimento da forma primordial dos agrupamentos hominídeos, onde um pai violento e enciumado possui todas as fêmeas e expulsa seus filhos à medida que crescem. Trata-se aqui do tema da "paternidade mítica” onde Freud apóia-se na descrição da refeição totêmica elaborada por Robertson Smith:

"Los hermanos expulsados se reunieron um dia, mataron al padre y devoraron su cadáver, poniendo así un fin a la existencia de la horda paterna. Unidos, emprendieron y llevaron a cabo lo que individualmente les hubiera sido imposible. Puede suponerse que lo que les inspiró el sentimiento de su superioridad fue un progreso de la civilización quizá, el disponer de un arma nueva. Tratándose de salvajes caníbales era natural que devorasen el cadáver. Además, el violento y tiránico padre 
constituía seguramente el modelo envidiado y temido de cada uno de los miembros de la associación fraternal y al devorarlo se identificaban con él y se apropriaban una parte de su fuerza. La comida totêmica, quizá la primera fiesta de la Humanidad, seria la reproducción conmemorativa de este acto criminal y memorable que constituyó el punto de partida de las organizaciones sociales, de las restricciones morales y de la religión”.(p.1838)

Após o ato consumado - o assassinato - os irmãos perceberam que nenhum deles poderia ocupar o lugar do pai, correndo o risco de retornarem indefinidamente a situação anterior.

Uma vez morto o pai, os filhos tiveram seu ódio saciado, os sentimentos para com o pai que outrora eram ambivalentes, se expressam agora, apenas pelos aspectos amorosos, mobilizando ao mesmo tempo um sentimento de culpabilidade e uma "obediência retrospectiva”. O morto passa então a deter um poder muito maior do que quando vivo e motivados pela culpa os irmãos escolhem um substituto do pai: o totem. O que lhes era vetado, pela proibição do pai, passa a ser a partir deste momento por decisão dos irmãos. Proíbem a morte do totem, por um pacto feito com o pai ou o totem seu substituto, que em troca lhes dará proteção, cuidado e indulgência, tendo que abdicar também das mulheres do pai que justamente haviam libertado.(Freud,1912, p.1839)

Por meio desta festa canibalesca de caráter ambivalente expressam-se os elementos próprios do complexo paterno - odiar o pai e amá-lo, admirá-lo. Desta forma, após suprimi-lo e aplacar seu ódio com este ato, o caminho identificatório permite a manifestação afetiva de uma ternura exagerada, verdadeira veneração. Mas resta o sentimento de culpa, que engendra na sua origem estes dois interditos atuantes na situação edípica a partir dos desejos recalcados da morte do pai e das exigências sexuais dirigidas à mãe.

Todo esse processo organiza no pensamento freudiano a forma como emergiu o totemismo, base através da qual se constitui toda a construção da instituição religiosa. A religião totêmica surgiu da culpa vivenciada pelos filhos tentando aplacar esse sentimento e apaziguar ao pai. Todas as outras religiões seguem esse mesmo princípio em que uma culpa original precisa ser reparada. 
Com a estrutura teórica proposta por “Totem e Tabu” contamos com alguns elementos que permitem fazer as relações entre a categoria do pai morto e a emergência do sujeito. Sob esta perspectiva, o complexo de Édipo é, segundo Freud, a expressão dos dois desejos recalcados - desejo do incesto e desejo de matar o pai contidos nos dois tabus próprios do totemismo, trata-se aqui de sua universalidade, pois traduz as duas grandes proibições fundadoras de todas as sociedades humanas.

Se por um lado com este estudo, em busca da universalidade do complexo de Édipo, Freud caminha por terrenos alheios levantando uma hipótese mítica (ciente da possibilidade de ser inverossímil) acerca da origem da sociedade humana gerando justificadas críticas, por outro lado, a questão que ele coloca é fundamental e de ordem epistemológica ou seja, o problema natureza-cultura que nos remete à origem do homem e por sua vez, ao estatuto do pai primitivo.

Com Lévi-Strauss (1982) a descoberta freudiana pôde ser redimensionada por esta via, onde esse autor se desfaz do mito que a envolve, reconhecendo na proibição do incesto a regra universal instauradora da vida social. Assim, todas as sociedades humanas são normativizadas e regulamentadas, devendo ser consideradas em estado de cultura, inclusive as sociedades primitivas. Deste modo, o estado de natureza na realidade é uma ficção, na medida em que só é possível pensar o homem numa cultura, portanto, a cultura só pode aparecer como a única natureza do homem. $\mathrm{Na}$ busca do substrato comum, este autor situa nas regras que ordenam as trocas matrimoniais, o ponto onde figura sempre uma lei universal que é a da proibição do incesto, constituindo-se como o critério rigoroso que permitirá separar a cultura da natureza, respectivamente, distinguir estritamente o cultural e o natural no homem. É fundamentalmente a partir de uma falta que se inaugura a cultura. Dessa forma, é desta proibição originária do incesto que tenta dar conta o mito freudiano do pai da horda primitiva, remetendo-nos a partir da dinâmica edipiana - ordenada pela dialética do desejo em face da diferença dos sexos - à questão do pai em psicanálise. ( in Dor,1991, p.21-29) 
Freud em nenhum momento realizou uma exposição sistemática a respeito do complexo de Édipo, sendo necessário no entanto situá-lo nos diferentes momentos do seu pensamento, possibilitando abarcar a sua abrangência enquanto conceito central nesse referencial teórico.

Em 1914, momento em que elabora a conceituação em torno do narcisismo, retoma os caminhos sobre os tipos de escolha de objeto - narcísica (o objeto é escolhido segundo o modelo da própria pessoa) e anaclítica (o objeto é escolhido apoiado nos objetos das pulsões de auto-conservação - à mulher nutriz/ao homem protetor) estabelecendo ainda as relações do complexo de Édipo com o ideal do eu, enquanto projeção futura de um substituto do narcisismo perdido da infância.

Nas “Lecciones Introductorias Al Psicoanalisis" (1916), especificamente, na conferência XXI, “Desarrollo De La Libido y Organizaciones Sexuales”, Freud retoma a questão da pulsão sexual na época da puberdade, como uma intensificação da libido no seu reaparecimento. A primeira escolha objetal (na primeira infância) assumirá uma orientação definitiva embora se constitua apenas como um ensaio do que de fato se realizará na puberdade com toda sua intensidade de caráter libidinal. Para emancipar-se de seus pais há necessidade: do desligamento dos desejos libidinosos dirigidos à mãe - dirigindo-os a um objeto não incestuoso, reconciliar-se com o pai frente a permanência de uma hostilidade ou emancipar-se de sua tirania. Este trabalho se impõe a todos, mas dificilmente alcança-se um resultado ideal, assim para Freud:

"Los neuróticos fracasan por completo en ella, permanecen sometidos toda su vida a la autoridad paterna y son incapaces de trasladar su libido a un objeto sexual no incestuoso. En este sentido es como el complejo de Edipo puede ser considerado como el nódulo de las neurosis”.(p.2333) 
Lembremos que em “Duelo Y Melancolia” (1917) é realizada a explicação de como um sujeito confrontado com a perda do objeto de desejo reage identificando-se com ele, ou seja, trazendo para dentro de si este objeto. Gera-se assim uma peculiar transformação do ego, que desta forma passa a ser o próprio objeto. Esta equação: carga de objeto - perda da relação objetal - regressão à identificação, que é a mais primitiva forma de relação, será não só o mecanismo de um fenômeno patológico como na melancolia, mas também a base de um processo evolutivo e constitutivo do sujeito.

Em 1921, Freud descreve o complexo de Édipo nos mecanismos de identificação em "Psicologia De Las Masas Y Analisis Del Yo", analisa as duas ordens de laço com o objeto, um francamente sexual enquanto outro da ordem da identificação, ou seja, o menino revela o desejo pela mãe, buscando imitar o pai, identificação esta que adquire um matiz hostil diante do rival comportando uma ambivalência, podendo inclusive ocorrer uma inversão, onde o sujeito adotaria uma atitude feminina e o pai se transformaria em objeto de satisfação.

A partir da segunda tópica, Freud, com sua concepção estrutural da mente humana, respectivamente em "El Yo Y El Ello" (1923) reafirma os aspectos ambivalentes do complexo de Édipo, referindo-o agora como completo, onde num extremo se encontra o complexo de Édipo positivo e no outro o invertido ou negativo, enquanto nesta intermediação revela-se de forma completa com distinta participação de seus dois componentes, cada qual com ambas tendências integrantes. A partir do naufrágio do Édipo, ocorre uma identificação com o pai e uma com a mãe, que forma no eu a presença de um resíduo, caracterizando em parte uma modificação do eu que se constitui no supereu, portanto de valor estruturante para o aparelho psíquico como resultado da fase sexual dominada pela dinâmica edípica.

\subsubsection{A conflitiva edípica interpolada pelo narcisismo}

Com a articulação do complexo de Édipo à fase fálica e ao complexo de castração em “ La Organización Genital Infantil” (1923) situamos por fim o que chamaremos de um terceiro modelo deste complexo edípico, que se caracteriza principalmente pela interpolação do narcisismo atrelado ao referencial fálico. Freud estabelece neste ponto, uma diferença entre o Édipo masculino - cujo complexo de castração determina a sua saída e o Édipo feminino - onde o complexo de castração 
possibilita a sua inserção nesta conflitiva. Neste momento culminante do complexo edípico só um órgão conta: o falo - designador de um objeto cuja característica principal é a de não existir, referendado à função simbólica desempenhada pelo pênis na dialética intra e inter-subjetiva. Articulado ao referencial do narcisismo, não há lugar para o meio termo do ponto de vista fálico, ou seja, ser tudo (para alguém) ter alguém (plenamente).

A partir deste pressuposto terceiro modelo já não se sustenta mais a idéia inicial de Freud de que o complexo de Édipo tanto para o menino como para a menina, mutatis mutandis se equivaliam. Retomando a tese da libido única, de essência masculina e partindo da concepção do momento da organização fálica da libido circunscrita na dinâmica edipiana, respectivamente no confronto da criança com a triangularidade, podemos entender a base narcísica do primado do falo último elo de união com a figura materna.

Assim, enquanto o menino reconhece na figura paterna o obstáculo à realização de seus desejos, abandona o investimento feito à mãe e evolui para uma identificação com o pai, a qual lhe permite, mais tarde, uma outra escolha de objeto e novas identificações, saindo portanto do Édipo através da angústia de castração; ao contrário do menino, na menina a relação do complexo de Édipo com o complexo de castração é muito diferente, pois é justamente pela castração (inveja do pênis) que a menina se insere nesta conflitiva, desliga-se de um objeto do mesmo sexo (mãe), desloca-se para outro de sexo diferente (o pai), "renunciando" ao pênis e abandonando o investimento ao primeiro objeto (mãe) apenas numa tentativa de obter compensação, resvalando ao longo de uma equivalência simbólica - do pênis para o bebê, culminando o seu Édipo no desejo de obter como presente um filho do pai. Goldgrub (1989) situa com clareza a leitura desta passagem:

“... o valor que o pênis tem (a inflação que o transforma de órgão anatômico em instrumento mágico) provém daquela cujo amor representa o bem máximo, desejado por todos os humanos, sem distinção de sexo, Enfim, se o pênis torna-se fálico, não é senão para obter o falo - ou seja, o amor incondicional representado pelo desejo da mãe, representado por sua vez pela proximidade a seu corpo. Mas se o pênis pode tornar-se fálico por via da 
demanda de bebês, é porque reciprocamente o bebê também é fálico, e pelo mesmo motivo...”(p.61)

Podemos situar duas ilusões fundamentais no eixo fálico, consubstanciadas pelos verbos ser e ter: ser enquanto posição de objeto, (ser tudo para um sujeito fálico) e ter enquanto posição de sujeito (ter o falo para obter o objeto fálico)

Freud aponta para uma articulação fundamental entre o complexo de castração e sua significação do ponto de vista narcísico, especificamente na sua representação enquanto uma "ferida narcísica” onde diversos mecanismos da ordem do recalcamento/identificação, entre outros, são mobilizados internamente, concentrando-se na possibilidade de uma renúncia aos primeiros objetos de satisfação e uma espécie de “dissolução” desta conflitiva de valor estruturante para o sujeito.

Estes aspectos são amplamente considerados nos artigos “La Disolución Del Complejo De Edipo” (1924) e “Algunas Consecuencias Psiquicas De La Diferencia Sexual Anatômica” (1925) com as ricas articulações sobre a formação da instância do supereu e sua correspondente diferença entre o menino e a menina do ponto de vista intrapsíquico.

O complexo de Édipo feminino passa a ser estudado por Freud com maior profundidade nos textos "Sobre La Sexualidad Femenina" (1931) sublinhando os aspectos de renúncia tanto em relação à zona erógena (do clitóris para a vagina) como em relação ao objeto (da mãe para o pai) efetuada sob sinais evidentes de intensa hostilidade; em “Nuevas Lecciones Introductorias Al Psicoanalisis” (1933), especificamente na lição XXXIII "La Feminidad" o autor ressalta como a descoberta da castração constitui um ponto fundamental para a menina, desenvolvendo três caminhos possíveis no campo libidinal, sendo que o primeiro conduz à inibição sexual ou a neurose, o segundo aponta para uma transformação de caráter, desenvolvendo um complexo de masculinidade e por fim, a feminilidade em si. Particularmente, são aprofundados os aspectos que envolvem o ressentimento e hostilidade com a mãe, transferidos em suas escolhas amorosas posteriores.

Ao redor do eixo do complexo de castração temos a representação simbólica da ameaça de desaparecimento não de um objeto real - pênis, mas algo que concerne ao falo - objeto imaginário de caráter narcísico enquanto elo de completude com a 
figura materna (eu ideal), instituindo através do representante pai o princípio de realidade. Em termos de instância, falaremos do supereu, que corresponde justamente ao pai despersonalizado, aspecto este desenvolvido intensamente por Freud em “Inhibicion, Sintoma y Angustia” (1926) convertendo-se o medo à castração em uma angústia moral, abrindo um caminho de entrada para o social, para a cultura.

\subsubsection{O desamparo e a nostalgia do pai}

Em “El Porvenir De Una Ilusion” (1927) Freud examina a questão cultural e religiosa, falando sobre a necessidade do homem em humanizar as forças aterrorizantes da natureza, fazer delas pais, deuses que deverão protegê-lo e assegurar-lhe uma recompensa pelas restrições e conseqüentes sofrimentos impostos pela cultura. Tal situação encontra seu modelo original na infância, momento o qual os pais, em particular o pai, garante um papel protetor, ao mesmo tempo em que se faz temido pelas proibições que enuncia. Ramadam (1996) faz uma observação a este respeito que com clareza retrata esta dimensão freudiana relativa ao campo religioso:

\footnotetext{
"Quase todas as religiões, inclusive o cristianismo excetuando o judaísmo e o islamismo - cultuam uma figura mítica originada da conjunção carnal entre deuses e seres mortais. Essa figura mítica e redentora, tem suas vantagens polivalentes: sendo humana, ouve nossas preces e compreende nossas misérias; e, sendo divina, tem o poder do ressarcimento, da misericórdia e do perdão.” (p.166)
}

Por meio da cultura, pretende-se escapar ao desamparo, diante da dificuldade que o homem se depara na difícil tarefa de relacionar-se com outros e de suportar a vida, ambos igualmente geradores de angústia, ferindo seu narcisismo. Assim Deus, coloca-se na relação direta da superação do pai, promovedora de uma dimensão protetora, representada ulteriormente pela "nostalgia do pai”. 
A continuidade deste tema surge em seu livro "El Malestar En La Cultura" (1930) onde examina o caráter insatisfatório das relações humanas e o papel da cultura ao intermediar este sofrimento impondo restrições que por sua vez geram nova fonte de mal-estar. Freud refere-se à manifestação explícita da pulsão de morte e reflete sobre os meios encontrados pela cultura para conter a agressividade. Trata do supereu como um representante internalizado da lei, promovedor de uma tensão em relação ao eu gerando um sentimento de culpa, produto por um lado da angústia sentida pela criança diante da autoridade paterna, pois temendo não ser amada, a criança é levada a renunciar a satisfação pulsional; por outro lado, este sentimento de culpa é em parte resultante da introjeção da agressividade, gerada conjuntamente pela insatisfação intrínseca à própria renúncia.

Destacaremos, portanto, uma culpa - variante topográfica da angústia, que é fundamentalmente de ordem psíquica, onde em alguns casos, o sujeito precisa ser punido por algo. O processo neurótico relacionado à sintomatologia resultante do sentimento de culpa é tratado com toda sua intensidade, já desde os artigos: “Una Neurosis Demoníaca em el siglo XVII” (1923) e em “ Dostoyevski y el parricídio” (1928) derivando este sentimento da fantasia edípica que transborda para a realidade e busca uma culpabilização através de flagelos, castigos e penitências, para alívio do sintoma. O que importa não é quem tenha cometido o crime, mas quem o desejou e neste sentido, todos que o desejaram são culpados. Nestes textos são trabalhadas particularmente as fantasias infantis ambivalentes em relação ao pai, trazendo a castração como ponto central, relacionado também à figura de Deus, do Diabo e do Destino como faces deste pai, onde a relação do indivíduo com o objeto paterno fica transformada numa relação entre o eu e o supereu. Esta relação pode vir a restabelecer em si, um componente feminino decorrente da relação erótica para com o pai que deveria ter sido recalcada, objetivando um supereu de caráter sádico, numa relação com um eu masoquista, ou seja femininamente passivo, decorrendo daí a grande necessidade de castigo que detém uma espécie de satisfação no maltrato. 
Resulta que o castigo constitui-se no fundo como castração, possibilitando para Freud considerar que toda neurose oculta certa quantidade de sentimento de culpa inconsciente, reforçando por sua vez o caráter punitivo do sintoma.

Ao refletirmos sobre este percurso do lugar paterno dentro da obra freudiana, especificamente na sua dimensão dialética com a conflitiva edípica, podemos considerar um primeiro momento vinculado ao surgimento da psicanálise com a Teoria da Sedução, na qual Freud construiu uma teoria das neuroses, centrada numa concepção traumática, vinculada à figura da sedução representada pelo pai. Mas, o subseqüente abandono desta teoria, preserva a figura paterna colocando o foco central no fato de não se tratarem de seduções reais, mas de experiências fantasmáticas, apoiadas na sexualidade infantil. Observa-se deste modo que a subjetividade dentro da psicanálise centra-se num aparelho psíquico produtor de fantasias. (Birman,2000)

Nos anos 20, o pai é recolocado novamente numa concepção traumática do psiquismo, na medida em que, segundo Birman (2000), Freud “coloca em cena toda a violência da experência pulsional, a qual ele vai dar o nome de pulsão de morte”. Com esta colocação, este autor propõe compreender Freud como um pensador moderno, na medida em que, surge um pai que deixa de proteger o sujeito na sua condição intrínseca, remetendo-se, a partir daí, ao mal-estar na civilização, referindose à nossa condição moderna de desamparo, que não comporta cura, cuja experiência subjetiva será por ele denominada de “nostalgia do pai”, com reflexos na instância psíquica do supereu, no mundo fantasmático e nas diferentes sintomatologias.(p.37)

Este mesmo autor considera que na primeira tópica, Freud entendia ainda como possível "restaurar uma unidade psíquica, funcionando a figura do pai como uma instância de proteção”; não obstante as relações de oposição entre pulsão e civilização, Freud propunha “uma espécie de reconciliação entre estas duas facetas” cuja função de sublimação teria o efeito intermediador entre estes contrários. (p.38)

Na segunda tópica, a partir dos anos 20, em que Freud ressalta a difícil tarefa de suportar a vida, onde o pai é interpolado pela pulsão de morte, o sujeito está fadado ao desamparo, o mal-estar encontra-se agora no centro da psicanálise. 
Tecendo a manhã

Um galo sozinho não tece uma manhã: ele precisará sempre de outros galos. De um que apanhe esse grito que ele e o lance a outro; de um outro galo que apanhe o grito que um galo antes e o lance a outro; e de outros galos que com muitos outros galos se cruzem os fios de sol de seus gritos de galo, para que a manhã, desde uma teia tênue, se vá tecendo, entre todos os galos.

2.

E se encorpando em tela, entre todos, se erguendo tenda, onde entrem todos, se entretendendo para todos, no toldo (a manhã) que plana livre de armação. A manhã, toldo de um tecido tão aéreo que, tecido, se eleva por si: luz balão.

(Melo Neto)

Do ponto de vista das mudanças culturais, a pré-modernidade, de acordo com Fleig (2000), caracteriza-se por uma organização “segundo os princípios da hierarquia, holismo, da tradição e em práticas religiosas que corroboram o regime do patriarcado", a modernidade sustenta uma organização "segundo os princípios da igualdade, individualismo, autonomia, e em práticas religiosas secularizadas, isto é, esvaziar o céu de seus ideais para realizá-los na terra”, e a pós-modernidade, pressupõe "o fim dos ideais e suas narrativas, e a descrença no futuro”. Em conseqüência disso, este autor refere-se aos efeitos subjetivos marcantes, que se refletem nos modos de relação com o outro, propriamente no laço social.(p.23)

A inquietação própria da modernidade já se manifesta em Freud como pudemos ver, na produção de sua obra referendada a partir dos anos 20, cujos sinais apareciam tanto no conjunto das circunstâncias históricas marcadas pela guerra, como no andamento da própria atividade clínica que demandava uma reformulação da sua teoria sobre a dualidade pulsional, para comportar os fenômenos da ordem da compulsão à repetição, do masoquismo e do sentimento de culpa, que passam a ser articulados à pulsão de morte; vinculada inicialmente para o interior e só 
secundariamente volta-se para o exterior, manifestando-se então sob a forma da pulsão agressiva ou destrutiva.

No seu artigo “El Malestar en la Cultura” (1930) Freud dá continuidade à série de textos que abarcam o campo social e os processos da cultura, entendendo que tanto a evolução do indivíduo como a evolução cultural da comunidade sempre estão de certa maneira aglutinados. Por este motivo, sugere que a partir de uma analogia entre ambos (adotando extrema prudência neste raciocínio analógico) o social também “desenvolve um supereu” de uma época cultural determinada, fundado na impressão deixada pelos grandes homens da História, elaborando por sua vez seus ideais e erigindo suas normas. Assim, muitas expressões e qualidades do supereu podem ser reconhecidas com maior facilidade em sua expressão coletiva do que no indivíduo isoladamente. Com agudeza este autor reflete em sua obra algo da manifestação do cenário histórico em que está inserido e resgata a Ética como o sistema que toca no ponto mais vulnerável de toda a cultura respectivamente nas relações dos seres humanos entre si.

Assim, temos a questão do social como um problema presente e sempre lançado no horizonte freudiano, entendendo que a dimensão social constitui-se como um componente fundamental dos conteúdos psíquicos.

Aportes importantes em relação à função do pai e do campo social tem sido desenvolvidos no terreno lacaniano, nomeados como função paterna e sublinhados com a especificidade de suas formulações teóricas em relação ao lugar paterno e sua função de valor estruturante para o sujeito. Já em seu artigo sobre a família, Lacan (1938) refere-se a estes mesmos fenômenos que na sua essência convergem para um mesmo ponto, respectivamente a impossibilidade de cumprir com um ideal, abarca o sentimento de um "declínio da imago paterna”, dimensionando a Psicanálise como uma tentativa de valorização da paternidade e propondo-se, apoiado no pensamento freudiano, à sua reformulação simbólica, integrando os elementos referentes às relações arcaicas com a mãe, respectivamente, seu “encantamento alienante”, sua captação especular. Da conjunção destas reflexões com a idéia de tomar como centro de Totem e Tabu a noção de "pai-morto", Lacan no âmbito de sua teoria do significante passa a elaborar em 1956 a conceituação da “metáfora paterna”, grafando-a como "Nome-do-Pai”, onde na transição edipiana da natureza para a cultura, o pai interviria junto ao filho como privador da mãe, respectivamente 
fazendo-se representar como a própria encarnação do significante (do Outro) por chamar o filho por seu próprio nome, dando origem ao ideal do eu na criança.

Diante do questionamento sobre o que aconteceu com as diversas dimensões do pai hoje, ponto este destacado no presente estudo, alguns autores da atualidade, referendados em Freud e em Lacan, têm refletido e se preocupado com a abrangência desta questão no atual momento histórico, especificamente no seu desdobramento no âmbito das relações familiares e sociais (laço social). Neste sentido, as diferentes dimensões do pai, hoje, têm inevitavelmente seu impacto na educação, nas instituições e na própria clínica.

Como uma conseqüência da nossa prática, para tratarmos e situarmos o pai nos dias de hoje, recorreremos ao aporte destes autores da contemporaneidade que nos auxiliam dentro deste momento histórico a refletirmos sobre esta imago paterna, seu nomeado desfalecimento e conseqüente desdobramento no campo das relações. Permitimo-nos escutar a partir de Freud e para além do que ele pensou, pois entendemos tratarem-se de problemas vitais para a teoria psicanalítica, visando subsidiar-nos na nossa prática.

Birman (2000) remete-nos à “morte da figura sociológica do pai”, sendo associada por ele à morte de Deus, entendendo esta questão, que vai atravessar o século XX, como sendo produzida pela modernidade, tendo como conseqüência algo da ordem da "nostalgia do pai”, questão esta amplamente desenvolvida na ulterior temática freudiana do complexo paterno. Segundo este autor, esta manifestação nostálgica encontra-se no plano dos fantasmas, na manifestação sintomática e na própria organização psíquica com o supereu, estabelecendo-se uma ligação, entre a “perda do pai e a condição de desamparo”, onde, "nesta fórmula atual de mal-estar na civilização, não existe a possibilidade de haver a cura ao desamparo humano”.(p.38)

Birman (2000) considera que no mundo pré-moderno existiram formas de circulação e modos de organização, onde a figura paterna estava bem definida e enraizada. O mundo moderno sofre um abalo e desorganiza-se perante o gradativo desaparecimento da grande família patriarcal pré-moderna, tendo como desdobramento o mal-estar característico da modernidade, sendo este período, chamado por alguns autores de pós modernidade e por outros de modernidade tardia.

Este mesmo autor refere que na quebra desta soberania do pai (presentificada na figura da morte de Deus), perde-se a autoridade e a proteção deste 
pai, "grande Outro divino”, focalizando ainda na atualidade, algo por ele assim denominado como a "multiplicação dos discursos", acarretando numa fratura entre o enunciador e o autor do enunciado, elemento que inviabiliza hoje, contarmos com uma figura de autoridade soberana que possa oferecer uma sustentação absoluta, daí advém o mal-estar contemporâneo, que para Birmam assume fundamentalmente o sentido de um mal-estar masoquista, onde estabelece-se uma soberania cruel alimentada pela culpa e nostalgia em relação ao pai, evitando-se o desamparo via posições masoquistas, onde o sujeito não recorre a uma gestão lateral, horizontal dos seus laços com os outros, mas para não se ver nesta condição desamparada recria e submete-se a um Outro, à sua soberania cruel, cuja experiência subjetiva é apreendida na figura do masoquista.(p.41)

Jerusalinsky (2000) refere-se a Freud e mais explicitamente a Lacan, como autores que situam o pai na posição de uma função, “que consiste em sustentar o que de especificamente humano pode-se colocar em jogo na nossa espécie, ou seja, a linguagem”. (p.17)

Nesta direção do lugar do pai enquanto função, podemos dizer que o pai, para nos defender da angústia pode estar em qualquer lugar desde que seja convocado; se o pai falha, a angústia advém, o real emerge. Deste modo, ao falarmos desta crise da função paterna de suas falhas, até mesmo de sua pane, faz-se necessário uma distinção entre a articulação dos termos “modernidade, função” (ou seja, como se produz isso que se chama o Outro) de algo hoje referido como a “catástrofe da masculinidade”. O primeiro supõe que nos dias de hoje, cada um pode se apropriar deste todo saber, na apropriação de um saber sob a forma de conhecimento, lugar assumido pelo discurso científico todo-poderoso. O segundo refere-se a “este afundamento do suposto, que o falo está no pênis” como algo que neste momento histórico compõe o cenário das relações amorosas. Diante do declínio e das falhas desses lugares e distintas questões, surge o(s) sintoma(s) e o conjunto de manifestações subjetivas promovedoras de algum sentido, de alguma ordem de apelo ou demanda, na tentativa de promover algum tipo de sustentação enquanto um recurso supridor.(Jerusalinsky, 2000, p. 17-18)

Fleig (2000) propõe enfatizar “os deslizamentos da função paterna e sua progressiva substituição pelos modos de operar do discurso da ciência e seus corolários, como a exclusão do sujeito da enunciação (produção de enunciados impessoais, desconectados da situação histórica onde foram produzidos) 
enfraquecimento da responsabilidade, desaparecimento do sentido comum dos limites, obscurecimento da faculdade de julgar e de estabelecer uma hierarquia de valores”. É justamente à luz desta referência que este autor propõe compreendermos as patologias atuais da nossa cultura. (p.23)

O autor, ainda, retoma o conceito freudiano de complexo paterno, "simbolizando as duas funções do pai: o pai vivo e o pai morto, que comporta por sua vez, duas figuras, assim como o monarca do antigo regime se apresentava em dois corpos ('O rei está morto, viva o rei')”. Com a desmontagem do patriarcado, com a legitimidade e centro de referência ocupado pelo discurso da ciência, que propõe a "completa objetividade do real, onde o sujeito da ficção nada mais tem a dizer, não há nada a recalcar, onde tudo é dado por conhecido” decorre daí uma desestabilização da função do pai, com múltiplos desdobramentos que agora não se encontram mais dispostos verticalmente (hierarquizados) como na pré-modernidade, mas sim horizontalmente, correspondendo a novos arranjos do nome do pai.

O que se observa na nossa cultura , de acordo com Fleig (2000) é uma “deslegitimação do lugar do pai”, sendo necessário para reivindicar a sua posição, infinitas justificações, "não é mais a enunciação do mestre, enquanto ato de dizer, mas um conjunto acéfalo de enunciados”, totalmente impessoais, resultando segundo Fleig “numa radical subversão da possibilidade do exercício da função paterna”.

Orientado pelo pensamento de Lacan que propõe uma distinção entre paisimbólico (o pai morto, mítico, este "nome do pai” no singular que para Lacan hierarquiza o conjunto de significantes), pai imaginário ( grandioso, incastrável lugar de projeção do ideal do eu) e pai real (ao mesmo tempo, pai da realidade e paisintoma), Rassial (2000) sugere que em decorrência das diversas crises vividas a partir da modernidade, estabelece-se "o desaparecimento hoje da unidade da função paterna”. Nesta direção, segundo as considerações deste autor, primeiramente “o pai que decaiu é essencialmente o pai simbólico”, que por sua vez não tem nenhuma realidade, ele é o lugar mítico, mas esta dimensão simbólica do pai, é aquela que ao mesmo tempo limita a amplitude louca do pai imaginário e dá valor àquilo que o pai real produz". Ao contrário, “em relação ao pai imaginário, não há decadência”. Mas principalmente, “é a função do pai real que está comprometida em nossa sociedade, é o pai dos limites, mas não dos limites simbólicos (que orientam as interdições edípicas), nem os limites imaginários, mas do pai real que encarna este limite ao ato 
do sujeito, autorizando-o a jogar somente até este limite real”. Citando Lacan, este autor, refere-se “a este homem qualquer, 'o pobre tipo', que justamente é o agente da castração simbólica, aquele que limita, reduz ao mesmo tempo a expansão de um real ameaçador, gozo da mãe arcaica, e situa o campo do Outro simbólico”. Através de sua falha, segundo Rassial (2000), o pai real se manifesta nas patologias psicopáticas e aditivas do adolescente, referindo-se a "um conluio, entre o social, o super-eu coletivo e as ditas ‘novas mães’ para culpabilizar o pai’. (p.12-13)

Paralelamente a estas reflexões destes autores a respeito do lugar do pai na contemporaneidade, encontramos questões que com pertinência se articulam plenamente a estas crises, ou poderíamos também denominar momentos de passagem da atualidade.

Antelo (2000), nos fala da “interrupção dos registros da transmissão e da cultura", repercutindo diretamente em relação à formação das identidades. Neste sentido recorre a idéia de Bleichmar (1997) de um "mal-estar sobrante, onde as crianças deixaram de ser os depositários dos sonhos tardios dos adultos”, cuja sua representatividade está dimensionada no mal-estar na educação, condensando para este autor duas hipóteses: "por um lado, não há mais o longo prazo e, por outro, parece que não há mais crianças”.

Para fundamentar esta idéia, Antelo (2000) menciona uma série de expressões que nos dias de hoje, estão praticamente suspensas, tais como: “ O que você vai ser quando crescer?..., Você tem de ser alguém na vida..., Para que você possa ter aquilo que eu não tive...Onde você pensa que está? Você não está em casa...”.Todas estas expressões estão ligadas ao que se conhecia de mobilidade ascendente, a idéia de movimento, condensando implicitamente "o longo prazo e a espera”, hoje insustentáveis no imediatismo do presente. Assim, para este autor, as instituições, família e escola, mais o Estado, deixaram de produzir o que até há pouco tempo chamava-se de infância, frente aos abalos observados no sistema de valoração, filiação e na redistribuição dos lugares de ascendência sofridos na atualidade.

Kehl (2000) a partir das reflexões freudianas e lacanianas traz como objeto de debate entre os psicanalistas a idéia de função fraterna discutindo as perspectivas de suplência desta à função paterna, na medida em que possibilita separar a lei da autoridade do pai real. Ressalta que: 
“as experiências cotidianas compartilhadas com os irmãos permitem a quebra da ilusão identitária para o sujeito ao produzir um campo horizontal de identificações entre os semelhantes, secundárias em relação à identificação com o ideal representado pelo pai, mas essências no sentido da diversificação que possibilita quanto aos destinos pulsionais que têm que ser constituídos pela vida afora”. (p.39)

Discute esta questão particularmente dentro do período da adolescência, das grandes formações fraternas e nos grupos que empreendem este "esforço civilizatório”, na invenção de espaços simbólicos, campo das novas identificações exogâmicas na reedição da busca de reconhecimento.

Destaca que na orfandade simbólica a fatria é convocada a operar para desenvolver o sentimento de pertinência e de dívida simbólica para com a origem e o semelhante, comportando um trabalho de criação de linguagem que pressupõe portanto o coletivo, tal como a arte nos testemunha ao longo das diferentes épocas, criando acima de tudo uma interferência estética sobre o nó duro da realidade, novo espaço de dimensionamento e invenção do humano.

Do ponto de vista psicanalítico, estes autores têm estabelecido uma leitura sobre o lugar do pai na contemporaneidade e seus efeitos, propriamente na subjetivação, atravessada por este período histórico.

Observamos hoje, um individualismo exacerbado pelo narcisismo, com a globalização e o campo virtual como pontos referenciais de desmedida abrangência, sem sinalizações claras para acolher o sujeito em seu desamparo. O acesso fácil e rápido a um campo saturado de informações, lança o indivíduo numa ilusão de preenchimento, embora paralelamente o sujeito se sinta “dessubstancializado”. Assim, a delimitação de sua dimensão humana é a cada minuto questionada e confrontada, exigindo-lhe um árduo trabalho psíquico para garantir a si próprio alguma espécie de sustentação.

Entendemos que esse "mal-estar" apresenta uma relação direta com a clínica, representado no campo do sofrimento, nas exaustivas demandas de psicoterapia abarrotando as filas de espera das instituições públicas, na pressuposta “insuficiência” das figuras parentais para educarem os seus filhos, nos diferentes conflitos e num continuum, na própria ordem da psicopatologia, refletindo de certa 
maneira os impasses vividos na atualidade. Novamente cabe à ciência suprir com as suas inovações, que rapidamente se mostram ultrapassadas: acalmar os ânimos, em tempos agitados, oferecendo prontamente respostas, laudos e adoçantes da vida para torná-la enfim, e de uma vez por todas, suportável.

Silencia-se o discurso subjetivo em proveito de uma nova linguagem técnica pré-fabricada. Por esta via, o pai hoje fica reduzido aos espermatozóides assim como, o enigmático do erotismo e do desejo, que entremeiam a procriação ficam reduzidos a uma manipulação de substâncias. De fato, o que fica reduzido ou mesmo abolido é o fator humano em detrimento dos processos biológicos. Eliminado o pater semper incertus o que assistimos é que também as mulheres são “despossuídas” do terreno da procriação tradicionalmente considerado-lhes próprio. (Chatel, 1995)

Ouçamos as últimas notícias, publicadas na revista "Isto'é", em oito de janeiro de 2003:

\section{“Competição com Deus”}

...No lugar de células reprodutivas de pais como acontece tradicionalmente na espécie humana, a equipe chefiada pela bioquímica francesa Brigitte Boisselier, presidente da Clonaid, empresa surgida em 1997 de uma seita religiosa, produz uma réplica, usando apenas uma célula materna, acendendo o debate na comunidade científica e na sociedade... Espera-se agora um teste de DNA para provar se Eva primeiro clone humano, é uma cópia perfeita de sua mãe... Assim, antes de morrer, cada um poderia se transferir para um novo corpo.... (p.76-8)

Ainda atordoados com os espermatozóides, desfazemo-nos rapidamente deles para destacar que em meio a discussões éticas e preocupações técnicas, constatamos nos bastidores científicos, enquanto espectadores atônitos, a uma corrida contra o tempo na ânsia para clonar humanos, expressão máxima da cultura do narcisismo, da reprodução massificada, do anseio pelo corpo ideal, do ser humano perfeito, sem falhas.

Comprovações à parte, o que importa aqui é que pesquisa científica e seita religiosa unem-se desvendando no imaginário social, os mistérios da origem e do fim, numa superação onipotente e ostentosa do domínio absoluto do homem sobre os poderes da natureza, arrancando-o paradoxalmente do que ele possui de singular, da 
sua história, da sua incompletude, deixando-o agora sim, desamparado, sem legitimidade ou direito à herança.

Retomemos as reflexões freudianas que comportam e revelam seu caráter atual no texto de 1927 em “El Porvenir de uma Ilusion”, onde referindo-se à força das doutrinas religiosas, aos dogmas, sustentados independentemente da razão, define-os como ilusões, cuja característica mais genuína é a de ter um ponto de partida nos desejos humanos mais primitivos que as derivam, prescindindo em absoluto de sua relação com a realidade:

“...El secreto de su fuerza está en la fuerza de estos deseos. Sabemos ya que la penosa sensación de impotencia experimentada en la niñez fue lo que despertó la necessidad de protección, la necessidad de una protección amorosa, satisfecha en tal época por el padre, y que el descubrimiento de la persistencia de tal indefensión a través de toda la vida llevó al hombre a forjar la existencia de um padre inmortal mucho más poderoso...Bajo, las premisas de este sistema se formulan respuestas a los enigmas ante los cuales se estrella el humano deseo de saber, enigmas como la creación del mundo y la relación entre el cuerpo y el alma. Por último, para la psique individual supone un gran alivio ser descargada de los conflitos engendrados en la infancia por el complejo paternal, jamás superados luego por entero, y ser conducida a una solución generalmente aceptada...” (p. 2976-77)

Ainda neste texto, damos a palavra a Freud na seguinte constatação:

“Reflexiones sobre la situación actual. Hemos oído la confesión de que la religión no ejerce ya sobre los hombres la mísma influencia que antes. (Nos referimos a la civilización europea cristiana). Y ello no porque prometa menos, sino porque los hombres van dejando de creer en sus promesas. Concedamos que la causa de esta mudanza reside en el robustecimento del espíritu científico en las capas superiores de la sociedad humana...” (p.2982) 
Já aqui, fica estabelecida esta relação direta entre religião e ciência, assim como sua correspondente equivalência na cultura em termos do lugar que lhes é destinado. Neste sentido, considerando do ponto de vista substitutivo, delimitamos um dos lugares em que o pai hoje está colocado, respectivamente uma de suas faces, referendada no conhecimento científico, devidamente autorizado e legitimado para com seu caráter protetor dar conta do desamparo próprio da condição humana.

Sinais dos novos tempos... que resultam em variações de um mesmo tema reeditado no espaço intersubjetivo atual, demandando sistemas singulares de ancoragem para a referida “Insustentável leveza do ser” ... (Kundera, 1999) 


\section{DELIMITAÇÃO METODOLÓGICA E CAMPO CLÍNICO}

\subsection{Considerações sobre o campo de pesquisa em psicanálise}

Bleger (1963), ao tratar da problemática metodológica dentro da Psicologia, refere que nenhuma ciência pode por si só abarcar a totalidade de um fenômeno, sendo necessário efetuar uma segmentação dos respectivos fenômenos interrelacionados para encaminhar um determinado estudo. Menciona a presença de um fator de dispersão que ocorreu particularmente na área das metodologias científicas, tendo em vista as dicotomias dentro desta disciplina resultante dos diferentes campos e seus objetos de estudo. Considera que particularmente as ciências humanas têm sido relegadas quando comparadas aos métodos positivistas que buscavam sustentar um ideal de cientificismo, onde a intervenção do ser humano poderia ser plenamente eliminada alcançando uma objetividade máxima.

A revisão deste posicionamento asséptico dentro da ciência tem se manifestado através de novos posicionamentos em todos os campos científicos, onde a investigação passa a ser considerada como um processo que se constrói de complexidade abrangente, onde sempre intervém o ser humano com suas categorias de pensamento e a sua personalidade.(p.215-218)

Segundo este mesmo autor, "não há método objetivo puro”, considerando que a única forma de ser objetivo é estabelecer num processo de interação dialética um cuidadoso ajuste na relação entre o objetivo e o subjetivo. Assim , "objetivo, quer dizer sempre humanamente objetivo”, em outras palavras "historicamente subjetivo”. Afirma, ainda, que há sempre um "recorte" feito sobre os fatos investigados questionando a observação pura sobre os fenômenos, onde a conversão de uma observação para um dado científico ocorre somente a partir da consideração da variável e do enquadre com a qual foi observada. (p.223-228) 
Defende ainda a idéia de que a observação é uma função ativa e, portanto, o observador nunca está fora do campo que determina os fenômenos, ressaltando ainda que a maior objetividade a ser alcançada pressupõe considerar sempre a relatividade do conhecimento.

Apoiados neste enfoque faremos algumas considerações sobre pesquisa em Psicanálise, pois desde sua origem, em Freud, já se reconhece a preocupação em atribuir um caráter científico às suas descobertas, afirmando o determinismo dos fenômenos psicológicos, elaborando uma teoria sobre a prática do atendimento clínico através do método da Associação Livre.

No início de seu trabalho Freud (1895) vincula-se ao modelo neopositivista de ciência, onde os dados deveriam passar necessariamente pela prova da verificação. Com a dimensão da fantasia, a investigação sobre a noção de compulsão à repetição e posteriormente sua elaboração conceitual sobre a pulsão de morte, o pensamento freudiano passa a ressaltar a complexidade deste campo clínico, onde a busca não se dá propriamente na ordem da verificação de uma história cronologicamente organizada, mas sim, na busca de um sentido sobre a história construída. Desta forma, o modelo de pesquisa em psicanálise fundamenta-se enquanto prática do diálogo, constitui-se como experiência interpessoal e interpretativa, cujo eixo substancial se apóia na transferência enquanto campo que subsidia o pensamento clínico.

Para Safra (1992), o relato do material clínico é sempre um modelo construído a partir de um certo recorte, o do analista, entendendo que a importância do reconhecimento desse limite é premissa fundamental para que se alcance a objetividade.

Quanto à preocupação de alcançar uma exatidão do material na pesquisa clínica, encontramos em Mezan (1992) considerações a este respeito, referindo-se a um "fantasma mítico" que inviabiliza muitas vezes o uso, numa obra acadêmica, de fragmento, trecho ou parte do próprio material clínico. Neste sentido, é necessário para este autor, do ponto de vista do psicanalista, um grande investimento no processo de pensamento, exigindo um grau razoável de tolerância à frustração a partir da capacidade de suportar a incerteza. (in: Silva, 2001)

Baseando-se nestes autores, estudiosos da complexidade do campo clínico, pretendemos focalizar a dimensão da temática paterna, do ponto de vista psicanalítico, dentre os inúmeros fenômenos que constituem a subjetividade da criança e suas manifestações na clínica. 


\subsection{Caracterização da demanda e da Instituição: a singularidade de seu campo}

O Instituto de Assistência Médica ao Servidor Público Estadual (IAMSPE) constitui-se em uma autarquia, sendo uma Instituição que atende aos funcionários públicos, seus familiares e dependentes de todo o Estado de São Paulo. Como Hospital Geral, referido como Hospital do Servidor Público Estadual “Francisco Morato de Oliveira” (HSPE) recebe os pacientes em regime de internação, em diferentes especialidades clínicas, contando também com um setor ambulatorial que atende a população em regime de consultas.

Especificamente o Serviço de Psiquiatria e Psicologia Médica, foi criado em 1964, atualmente conta com uma Enfermaria para internações psiquiátricas, um Hospital-Dia (HD), onde os pacientes permanecem apenas um período (diurno) no hospital e um Ambulatório que promove consultas e atendimentos realizados pelos profissionais da Psiquiatria, Serviço Social, Terapia Ocupacional e Psicologia. Uma das prioridades da Instituição refere-se ao desenvolvimento de trabalhos em equipe multidisciplinar e interdisciplinar através das interconsultas que têm sido progressivamente solicitadas pelas diversas clínicas que compõem o hospital geral.

Trabalhamos como Unidade Psiquiátrica no Hospital Geral, valorizando a tendência de tratar o paciente dentro (ou próximo) de seu ambiente original, privilegiando o tratamento ambulatorial, sendo a enfermaria usada para internação completa (24hs) ou diurnas (6hs), somente quando indispensável. Ressaltamos que estas propostas de Unidade Psiquiátrica em Hospital Geral e o próprio regime de HD, dentro destas características institucionais constam entre as pioneiras no campo da saúde mental no Brasil. (Sonenreich \& Estevão,1996)

A Seção de Psicologia, atende aos pacientes das enfermarias - através das solicitações de interconsultas - e o setor ambulatorial que realiza triagens, psicodiagnósticos, psicoterapias, tanto na área infantil, adolescente como de adulto, num enfoque individual ou grupal.

Em 1983 tive uma primeira vinculação com a instituição, realizando o meu Aprimoramento em Psicologia Clínica, permanecendo nesta atividade por um período de aproximadamente dois anos. Desde 89, período em que ingressei nesta instituição, a prioridade do trabalho tem sido fundamentalmente voltada para o atendimento da demanda ambulatorial. Paralelamente a preocupação com a formação dos diferentes profissionais da área da saúde tem possibilitado e garantido um espaço 
de aprendizado mantendo neste instituto a residência médica, estágios e cursos de aprimoramento. A partir de 94 com o meu ingresso no PAP - Programa de Aprimoramento Profissional, especificamente na preceptoria e supervisão do Aprimoramento em Psicologia Clínica e Psicologia Hospitalar, promovido pela FUNDAP - Fundação de Desenvolvimento Administrativo - oferecido pela Instituição aos profissionais da área de psicologia (recém formados) observa-se um incentivo maior aos profissionais responsáveis por este trabalho, na direção de um aprofundamento e atualização de seu conhecimento, estimulando conseqüentemente o campo da pesquisa.

Contamos atualmente com 12 psicólogos para atendermos a demanda, além de oito bolsistas, psicólogos (aprimorandos) que durante o período de um ano realizam atendimentos clínicos supervisionados pelos respectivos preceptores.

Estruturalmente a Seção de Psicologia possui uma Coordenação que responde a uma Chefia, que por sua vez pertence à Clínica Psiquiátrica, de responsabilidade do Diretor Clínico.

De um modo geral, os encaminhamentos para a Psicologia são feitos pela Psiquiatria, porta de entrada do atendimento ambulatorial deste serviço e eventualmente pela clínica neurológica. A Psiquiatria Infantil encaminha para a Psicologia, quando necessário, os casos por ela atendidos, em função da demanda frente às respectivas problemáticas e em função das solicitações das demais clínicas da Instituição.

Em relação à rotina do serviço estabelecem-se diferentes momentos, no encaminhamento do pedido de atendimento de uma criança ou de um adolescente: primeiramente o paciente passa pela triagem, sendo agendado para o psicodiagnóstico; com o término deste, seguem-se os diferentes encaminhamentos para a criança ou para os pais quando necessário, ocorrendo a indicação de psicoterapia que poderá ser feita na própria Instituição, de acordo com as vagas disponíveis no momento. Especificamente para os pais, seguem-se algumas possibilidades de atendimento, de acordo com as diferentes ordens de conflito, tais como: psicoterapia individual, grupo de pais, atendimento ao casal parental. 
Nesta população observamos na maioria das vezes uma iniciativa da mãe na sua vinda ao ambulatório na procura do atendimento para a criança. De modo geral, o comparecimento do pai às entrevistas não ocorre por iniciativa própria. Frente à convocação do(s) pai(s), a sua ausência é justificada freqüentemente devido ao horário de trabalho, por vezes em função de desentendimentos entre o casal, repercutindo no afastamento deste pai de sua família acarretando numa incomunicabilidade com o mesmo, ou ainda, pela sua negativa em comparecer aos atendimentos devido aos aspectos psicodinâmicos inerentes ao caso. Constatamos que os impedimentos de comparecer ao ambulatório em algum momento do psicodiagnóstico em função do horário de trabalho são esporádicos, embora seja a justificativa utilizada com maior freqüência.

Paralelamente, do ponto de vista institucional, a convocação do pai é realizada com certa ambigüidade, ora enfatizada por alguns profissionais, ora negligenciada por outros, praticamente excluído no momento dos agendamentos realizados pelos funcionários que cuidam da recepção e recebem esta incumbência, em situações de gravidade, o pai é imediatamente lembrado e solicitado a comparecer com a maior urgência na Instituição. Pensamos que estas diferenças de posicionamento traduzem uma ambivalência reveladora de um momento histórico/social que atravessa a subjetividade própria do campo da paternidade e filiação, compondo também a ordem de sintomatologias que se manifestam na clínica atual.

Ao descrevermos e caracterizarmos o modo de ser da Instituição, pretendemos sublinhar um campo que também se oferece como lugar transferencial. Assim, este pai pode ser considerado em suas diferentes dimensões tanto pela família, como pela Instituição, pode ser excluído ou incluído/acolhido, pode ser inutilizado ou representado enquanto função que lhe cabe, pois partimos do pressuposto que é sobre os avatares de sua representação que repousa dinamicamente a possibilidade de conter a onipotência infantil e sobre o seu lugar dentro da triangulação edípica que adquirirá sua importância como elemento imprescindível na constituição do sujeito e portanto na complexidade do campo da filiação.

Circunscrever esta dupla vinculação - com os respectivos profissionais e com a Instituição, nos coloca neste continuum entre a psicologia individual e a psicologia social. Podemos dizer de acordo com Freud (1921) que: 
"En la vida anímica individual aparece integrado siempre, efectivamente, "el otro”, como modelo, objeto, auxiliar o adversario, y de este modo, la psicologia individual es al mismo tiempo y desde un principio psicologia social, en un sentido amplio, pero plenamente justificado”. (p. 2563)

Portanto, o atendimento clínico no campo institucional nos coloca na interface de contato entre o mundo público e privado, o que nos lança frente a dois problemas intimamente relacionados: a gênese do sujeito e a gênese do social.

Neste estudo ao caminharmos lado a lado com este cenário de fundo histórico-social, pretendemos nos situar dentro desta configuração mais ampla de um imaginário coletivo, cujas instituições são aqui seus representantes.

Desta maneira, sublinhar as “formas de convocação” deste pai(s) tanto como as suas "formas de presença”, enquanto lugar psíquico fundamental para a constituição subjetiva, nos autoriza a refletir sobre as vicissitudes do lugar e da função do pai, especificamente num questionamento da sustentação que o campo institucional pode promover nestes novos tempos, elemento primordial de interpelação do nosso trabalho clínico.

\subsection{Delimitações deste estudo}

Ilustraremos este trabalho, com recortes do material clínico de quatro pacientes, respectivamente dentro da faixa etária de 9-12 anos, ambos os sexos (duas meninas ( dois meninos) atendidos na Seção de Psicologia do Serviço de Psiquiatria e Psicologia Médica do Hospital do Servidor Público Estadual "Francisco Morato de Oliveira” (HSPE), na qualidade de um atendimento ambulatorial.

Todos os casos foram encaminhados ao serviço pela Psiquiatria Infantil, cuja demanda e ordem de queixas apresentadas, embora diversas, podem ser contextualizadas dentro da área escolar e nos conflitos vividos dentro do grupo familiar/social. Assim, para estas crianças, os problemas apresentados demandavam atendimento por interferirem em diferentes graus, em áreas importantes de suas vidas. O motivo inicial manifesto apresentado pelos pais, situava-se no contexto da 
escolaridade tornando-se ao longo da entrevista uma queixa secundária aos conflitos de relacionamento no meio familiar, que se expandiam para as relações sociais.

Não foi priorizado o estado civil do casal parental como critério prévio de escolha dos casos para compor esta ilustração. Considerando o objetivo central deste estudo como sendo a focalização do lugar e função do pai na constituição psíquica do filho, ou seja na leitura do lugar deste pai na subjetividade desta criança, a condição civil do casal não garante ou assegura por si só a configuração desta função, compondo-se enquanto variável como mais um elemento da sua história de vida

A faixa etária da população aqui constituída (9-12anos) encontra-se num momento final da infância, podendo já ser circunscrito como um momento de passagem (puberdade), atendendo porém ao critério institucional que recebe na “área de infantil” pacientes até os 12 anos de idade. Os dados obtidos nas entrevistas não se constituem em queixas atuais tendo já sido estabelecidas em anos anteriores.

A preservação do sigilo será mantida através da escolha de nomes fictícios, da alteração de alguns dados e informações que possam eventualmente favorecer a identificação dos pacientes.

Dentro deste estudo qualitativo, seguimos o referencial teórico e metodológico da psicanálise, especificamente apoiado nesta reconstrução histórica dos conceitos freudianos até aqui destacados, entendendo que é neste diálogo permanente entre teoria e clínica que se instala o campo da experiência psicanalítica.

Partindo desta escuta psicanalítica, pretende-se sublinhar os aspectos psicodinâmicos relacionados à figura do pai que comportam as diferentes queixas problematizadas na clínica de crianças.

O desenvolvimento deste estudo situa-se dentro de um processo psicodiagnóstico, especificamente focalizando o momento inicial deste procedimento, ou seja, as entrevistas preliminares realizadas com os pais e individualmente com a criança, situando-se nesta etapa a delimitação do material clínico aqui utilizado.

Já em 1912, Freud em “Consejos al médico en el tratamiento psicoanalítico" propõe algumas regras técnicas entre as quais, refere-se ao estabelecimento de um contexto definido (setting) para a escuta psicanalítica através da atenção flutuante, ou seja, sem recorrer a uma seleção prévia dos conteúdos apresentados pelo paciente, aspectos que como pressupostos psicanalíticos 
diferenciam a técnica destas entrevistas iniciais de uma anamnese. Ainda em seu artigo, “La Iniciacion del Tratamiento” (1913), Freud destaca a importância de estabelecer um período preliminar com o paciente antes de propriamente assumi-lo em análise, período este de "motivação diagnóstica” que não seja demasiadamente prolongado, com o intuito de estabelecer um raciocínio clínico sobre o caso.(p.166163)

É justamente nesta direção que valorizamos este momento preliminar do processo diagnóstico. Trinca (1983) refere que o processo psicodiagnóstico pode ser estruturado de diferentes maneiras sendo necessário, no entanto, preservar referenciais que sustentem metodologicamente sua estruturação.

Assim sendo, procuraremos configurar nas entrevistas, através de questões amplas, um campo psíquico estruturado especialmente pelo paciente, já que “parte da vida do paciente se desenvolve em relação a nós e frente a nós”, possibilitando nesta situação, apreender os processos inconscientes que este espaço contempla. $\mathrm{Na}$ realidade, é na relação entre entrevistador e entrevistado que o campo da entrevista se determina, cuja configuração deverá ter como ponto de partida e ser dirigido principalmente pelo modo de ser do entrevistado, diferenciando-se de uma anamnese, cuja finalidade prioritária é a compilação de dados. (Bleger,1964, p.9-15)

Algumas condições são necessárias para a obtenção deste campo particular, permeado principalmente por uma escuta que visa abarcar a dimensão inconsciente dentro desta relação interpessoal, devendo ocorrer a partir de um determinado enquadramento. É numa escuta do conteúdo latente, através das expressões, gestos, lacunas, dissociações, contradições, atos falhos, nestas configurações das manifestações defensivas, conflitivas e de angústia, na leitura do lugar transferencial, especificamente na escuta de como cada um tem organizado sua história de vida e o seu presente que esta dimensão inconsciente dentro da psicanálise pode ser abarcada. Por constituir-se ainda numa fase preliminar, a situação de adesão afetiva à figura do terapeuta, que ainda não se encontra plenamente constituída, poderá ser delineada a partir da demanda, no momento de explicitar o motivo da consulta, tanto seja ele expresso pelos pais como pela própria criança.

Dentro deste procedimento, orientamo-nos realizando inicialmente as entrevistas com os pais e posteriormente com seus filhos. As entrevistas realizadas somente com a mãe foram determinadas pelas circunstâncias e particularidades inerentes ao próprio caso. 
Em relação às crianças, colocamos uma pasta (individualizada) contendo material gráfico, comunicando a elas a possibilidade de fazerem uso deste material, caso tivessem interesse ou mesmo quando convidadas a fazerem algum desenho. Apenas em um caso, respectivamente a criança de 9 anos, agregamos uma caixa contendo material lúdico, abrindo um espaço associativo também através do brinquedo, pois, assim como o desenho nos aproxima do âmago das representações imaginativas do paciente, da sua afetividade. Priorizamos a conversação associada aos respectivos materiais em função da faixa etária, tendo como objetivo principalmente favorecer o processo de associação na singularidade deste contexto de atendimento.

Ilustraremos a conceituação teórica freudiana com os recortes destes materiais clínicos, trabalhando essencialmente no campo da exemplaridade e não da generalização. Buscaremos a partir da queixa, ou seja, da escuta destes pais e da criança compreender a lógica subjetiva de suas condutas, freqüentemente para nós nada lógica quando enfocada a partir da “estranheza” própria da sintomatologia.

Considerando a densidade e complexidade teórica abordada ao longo da obra freudiana, neste recorte longitudinal, optamos pela exposição do material clínico a partir de fragmentos das entrevistas realizadas, entendendo que este modo de exemplaridade, possibilita maior abrangência da escuta dirigida à dinâmica intrafamiliar(pais/filho) enfatizada já neste primeiro momento.

O relato dos casos foi fundamentado no material originado da reconstrução destas entrevistas iniciais com os pais e com a criança. Este procedimento da reconstrução é regularmente utilizado no trabalho clínico para registro, supervisão ou estudo de caso. Neste trabalho embasado na citação de trechos das entrevistas preliminares com os pais e das primeiras sessões diagnósticas com as crianças, procuramos preservar em ambas, as expressões/palavras e comentários originalmente utilizados no discurso da respectiva família.

Seguiremos portanto, na linha da interlocução entre a conceituação teórica e as manifestações clínicas. 


\subsection{Apresentação e discussão do material clínico}

Através dos recortes clínicos aqui apresentados e do referencial adotado neste trabalho, faremos uma leitura sobre o lugar do pai na manifestação subjetiva das diferentes problemáticas, circunscrita já nas primeiras entrevistas. ${ }^{9}$

\section{CASO ROBERTO}

O primeiro paciente chamaremos de Roberto, tem 12 anos, está na sexta série, sendo encaminhado para o Ambulatório de Psicologia do HSPE, apresentando como motivo inicial da consulta "dificuldades na escola e no relacionamento em casa, com a mãe”.

Nas (duas) entrevistas somente comparece a mãe, iniciando com o seguinte relato:

Meu filho não estuda, quase foi expulso da escola, decidi transferilo ainda este ano, para uma escola mais próxima de casa. Com um grupo de colegas durante a aula estava vendo revistas pornográficas e ao ser advertido pela professora, ficou extremamente agressivo, chutando o portão e desaparecendo durante um período do dia.

Diz ainda:

Freqüentemente a escola se queixa das atitudes do Roberto, pois ele não segue as normas e o regulamento. Está desinteressado pelo estudo, encontra dificuldade em acompanhar as matérias, apesar de já ter sido considerado um bom aluno. Mente, inventa que perdeu dinheiro, mas na realidade gastou, diz que vai para a escola, mas acaba indo para a casa de outras pessoas... está agressivo. Eu bato, brigo, fico nervosa, mas não adianta nada.

\footnotetext{
9 Os recortes do material clínico foram reconstruídos após o término de cada entrevista, procurando preservar as expressões próprias registradas durante o atendimento. Manteremos esta reconstrução em itálico com o intuito de destacar seu conteúdo. Alguns dados foram modificados e outros omitidos, visando preservar a identidade dos pacientes.
} 
Atribui a mudança de Roberto à morte do avô (há 3 anos) com quem era muito ligado, comentando:

A partir da perda do meu pai (o avô), meu filho não aceita mais comando, acha que é independente, auto-suficiente, considera-se o homem da casa, decidindo tudo por si.

Frente ao pedido do comparecimento do pai de Roberto ao Ambulatório, a mãe menciona:

Não tenho notícias dele há 6 meses, não sei onde ele está atualmente, talvez tenha se mudado para outro estado, não sei a quem recorrer para encontrá-lo.

Roberto é filho único, reside atualmente com a mãe e a avó. Seus pais se separaram quando tinha 9 anos (na véspera de seu aniversário), mantendo a partir daí, pouco contato com o pai, que por sua vez, também se mantém distante. Nesta entrevista inicial a mãe comenta:

No meu casamento, esperava um marido carinhoso e não era nada disso, eu tive que cuidar de tudo sozinha, ele só pensava no carro e eu no enxoval, ele nunca colocou a mão na minha barriga, foi uma grande desilusão...Queria que o pai de Roberto fosse outra pessoa...

Casou-se com um homem 27 anos mais velho, já com filhos de duas uniões anteriores e lembra:

Eu sempre quis ter filho, pensava numa menina, mas logo senti que era um menino. Já o pai, queria muito uma menina e não abria mão, tinha até escolhido o nome, Gabriela, ele ficou muito decepcionado com o nascimento de um menino, dizia que, em relação às meninas dava para ter certeza que eram meninas, mas em relação aos filhos, sentia medo que virassem gays... 
Menciona que entre os filhos dos dois casamentos anteriores de seu exmarido, este teve apenas uma menina que veio a falecer de uma doença grave. Comenta ainda que, quando Roberto era pequeno perguntava:

Mãe, você ficou muito chateada pelo fato de eu ter nascido homem?

Sobre a vida conjugal, relata ainda:

Meu ex-marido era nervoso, agitado, por um cisco começava a brigar, nós vivíamos tendo atritos devido ao fato de residirmos no mesmo quintal com os meus pais, em função da interferência constante deles com a educação que dávamos ao Roberto...Quando discutíamos, eu via algumas vezes que o meu filho ficava tenso, com as mãos fechadas em punho, como se ele pensasse: se eu fosse um homem eu enfrentaria este pai... Com a saída do meu ex-marido de casa, acho que ficamos em paz...

Refere, que o pai de Roberto fazia uso de anfetaminas, para manter-se acordado, pois trabalhava há 30 anos como segurança no período noturno, justificando por este motivo o seu nervosismo e suas alterações. A mãe diz ainda sobre o filho:

Roberto sempre foi uma criança precoce e auto-suficiente, desenvolvendo-se rapidamente, andou, falou cedo, é muito esperto. Com um ano e meio, meu ex-marido me obrigou a tirar a chupeta dele, dava a impressão que ele sentia raiva do filho...

Logo após a separação, Roberto chegou a sair com o pai algumas vezes, mas o pai não cuidava direito dele, pois ele voltava com machucados, até mordida de cachorro...

Roberto não quer que o pai volte para casa, vive dizendo que agora a família está em paz, ele sente muita raiva do pai, motivado pelas atitudes dele, queixa-se da falta do avô, comentando que seu avô, agora sim ,estaria feliz se soubesse que nós (mãe e filho) nos livramos daquele traste... 
Durante as entrevistas esta mãe mantém-se prolixa, mostra-se ansiosa, chora quando se refere ao filho, à sua conduta, solicitando aparentemente alguma orientação efetiva sobre o modo de agir perante esta problemática, numa demanda por um "especialista” enquanto lugar de autoridade, que possa intervir perante as atuações do filho no meio sócio-familiar. Neste primeiro momento, demonstra sentirse desprovida de qualquer recurso interno para posicionar-se, frente a uma certa ruptura na relação mãe/filho diante do quadro sintomático do qual se queixa, diferindo da relação outrora fortalecida, que permitia a ambos manterem-se “estáveis” numa aliança de contrariedade e ressentimento em relação à figura paterna.

A seguir, faremos alguns recortes do conteúdo da primeira sessão diagnóstica realizada com Roberto.

Inicialmente, em relação ao motivo de sua vinda:

Eu acho que é porque tenho agido de modo estranho, quando menos espero agrido as pessoas, tô na minha e de repente fico com a cabeça cheia e acabo estourando, às vezes não quero falar, mas já tô falando, tento me controlar e não consigo...É muita responsabilidade para mim...

Sobre esta responsabilidade:

Quando meu pai separou da minha mãe, eu tive que assumir... veio uma carga muito grande para mim,.... meu avô já estava doente, aí quando ele morreu, veio mais carga, cuidar da avó, sobrou pra mim... e pra minha mãe também sobrou bastante...apesar de que quando ela estava casada tinha que fazer todos os papéis, ser pai, mãe, me educar sozinha...

Há alguns meses, minha mãe precisou operar um mioma, ela é louca, queria dirigir, eu tive que falar para ela ficar de repouso, só que mãe em casa é até pior porque ela fica nervosa... Mas a minha mãe é que acha que eu preciso vir aqui, eu mesmo não acho, eu resolvo os meus problemas. Eu faço o que bem entendo, ninguém tem que ficar nessa de mandar em mim, qual é? 
Em relação ao motivo de sua vinda, retoma:

Saí da escola, aprontei umas e outras. A diretora primeiro disse que me expulsou, mas aí quando a delegacia escolar ligou, ela disse que não tinha me expulsado que foi uma suspensão, aí minha mãe me transferiu para outra escola perto de casa porque eu disse que não iria mais lá...

Um colega levou para a escola uma revista pornográfica em quadrinhos, e você sabe, a gente tem aquela curiosidade. Aí um menino viu e contou para o guarda da escola, foi quando o colega que trouxe me falou, pra catar a revista e ir embora. Aí eu resolvi jogar do outro lado do muro da escola, mas o professor viu e queria me mandar para a orientadora educacional. Eu não queria ir e comecei a chutar o portão, foi quando estourou, vieram a diretora e o vice-diretor, mas eu estava tão quente que peguei o ônibus e fui para a casa de um colega, pensando em dormir na casa dele, mas acabei voltando para a minha casa...

Sobre a sua família:

Minha mãe vive nervosa, toma até calmante, não quer que eu ande só, tenho que ficar avisando onde estou...ela quer ficar mandando o tempo todo, mas não é bem assim, eu quero me virar.. arrumar um bico, só que ela não deixa. Meu pai era como se eu nunca tivesse tido, ele nunca ligou para mim, a única coisa, ele me dava camiseta do time de futebol que ele é fanático...ele dizia que a criança só vale quando está com a mãe, para ele só vale a mãe. A última vez que eu saí com ele, foi há seis meses, ele ligou perto do meu aniversário, para dar parabéns, de lá para cá não tive mais contato, também não quero nem saber...não tô nem aí...não serve pra nada, como diz a minha mãe, é um traste... Sinto falta do meu avô, mas eu não chorei quando ele morreu. 
Sobre os colegas e o que gosta de fazer:

Lá na rua, junto com os meus colegas, eu curto skate, games, converso sobre as minas, com quem vai ficar, ou se já ficou...em casa eu curto vídeo games, gibis...quero ficar na minha. Teve uma vez, na casa do meu primo que pegamos filmes pornográficos para assistir, já tinha pintado antes, já tinha visto, mas, no dia, rolou até cachaça, quase fui atropelado, meu primo quase se afogou (rindo), precisamos até ficar na cama, não conseguíamos levantar, bebemos mais que qualquer adulto bebe, minha mãe ficou decepcionada....Acho que não tem porque estar aqui na psicologia, eu não preciso e não quero, só vim pra ela parar de falar, todo mundo fica nervoso de vez em quando...

Numa segunda entrevista preliminar, Roberto menciona ter um grande interesse em fazer um curso de artes marciais e respondendo à solicitação de um desenho, comenta:

Vou desenhar a casa do Dragão Vermelho, é uma casa de um mestre japonês de artes marciais, e lá dentro é meio como um castelo, tem uma arena de treinamento, tem casas, é tipo uma casa grande com alojamentos.

Frente ao diálogo, que se estabelece no sentido de que Roberto passe a falar desse seu interesse, surgem diversas colocações a respeito deste desenho:

Neste lugar, ocorrem períodos de treinamentos, é um centro de treinamento, e nestes períodos, todos que moram lá tem que se relacionar bem, só pode ter raiva de inimigos de outros templos, não do mesmo, pois se tiver é morto...todos que estão ali para competir querem vencer a toda hora...os guerreiros japoneses não têm medo, eles lutam pela honra, quando sentem medo ficam de fora, não vão, não comparecem e são expulsos... 
Cada centro de treinamento é representado pela sua bandeira..., o dragão que é deste centro é um animal sagrado porque todos esses guerreiros têm que ter muita determinação, força, valentia e coragem, que são todas estas virtudes do dragão, por isso eles idolatram este animal, e todos têm que seguir o mestre, para aprender como se defender e lutar... Eu estou agitando para começar este curso...

Ao longo das entrevistas com Roberto, pudemos ouvi-lo na riqueza de suas colocações, com um domínio amplo do vocabulário, desenvolvendo de forma comunicativa os temas de seu interesse, que são compartilhados no seu grupo social - música, estórias em quadrinhos, skate, games e garotas, sempre procurando mostrar-se experiente a respeito dos temas que referem-se à sexualidade, aos interesses que são compartilhados por adultos. A maioria de seus colegas não são da sua idade, refere-se aos seus colegas como sendo mais velhos e para fazer parte deste grupo e sentir-se aceito tem que compartilhar dos mesmos interesses. Lembremo-nos que o seu pai também era mais velho, assim como a sua forte ligação com o avô.

Neste primeiro contato, embora respondesse às colocações feitas, mostra-se displicente, irreverente, sem propriamente expressar qualquer envolvimento, senta-se de lado, por vezes cobrindo parcialmente o rosto com o seu boné, colocando-se numa atitude questionadora, discutindo as regras estabelecidas pela mãe ou pela escola, sinalizando até mesmo, um ar de desafio em sua postura (cabeça erguida, nariz empinado) principalmente nos momentos em que menciona não ter sentido estar ali, e assim, não há inicialmente abertura, para que se estabeleça qualquer intervenção ou mediação frente a ordem de queixa apresentada. O que se passa neste momento, diz respeito somente à relação dele com a mãe, excluindo qualquer outra configuração deste relacionamento, sustentando-se numa postura claramente defensiva, onipotente, evitando uma aproximação com seu desamparo ou frente a presença de angústia decorrente de um confronto com uma vivência da ordem da castração.

Ao referir-se à sua vida familiar, fala a maioria das vezes de sua mãe, sugerindo a intensa ligação entre ambos. Refere-se ao pai, ressaltando o seu distanciamento, manifestando aparentemente um alívio pela exclusão deste pai do meio familiar, compartilhado por mãe e filho. O discurso de Roberto, é o discurso da mãe na manifestação afetiva em relação à figura paterna (traço identificatório), há 
ressentimento e desprezo em relação a este homem que "desaparece e ninguém sabe onde está, que é um traste e não serve para nada”, afinal não se constitui na pessoa que a mãe desejou, lembremo-nos da sua insatisfação e decepção ao longo do casamento.

Este recorte de material, obtido nestas entrevistas preliminares, permite-nos articular um raciocínio clínico tendo como operador o lugar do pai e sua função, dentro deste meio familiar. Dessa forma, o conteúdo manifesto de caráter defensivo, onde o pai fica num lugar desqualificado e de exclusão não tem representado nos últimos tempos a felicidade tão almejada neste reduto narcísico onde permanecem mãe e filho, lutas internas/externas com o meio social/escolar tem sido travadas. Os traços identificatórios na constituição de uma identidade sexual masculina o tem aproximado deste pai que, tal como ele, é expulso/excluído pelo seu enfrentamento e conduta dentro de um grupo social. Roberto apresenta-se “nervoso e intolerante”, tal como o pai, representando-o dentro de um aspecto identificatório na relação com a figura materna. A submissão às regras e disciplina escolar remetem-no a uma fragilidade, a uma diminuição de sua virilidade fixando-o numa posição regredida no relacionamento com a mãe, tendo que, do ponto de vista edípico, satisfazê-la. Lembremo-nos o desejo da mãe em ter uma filha e da decepção do pai diante do nascimento deste menino, com temores futuros frente a sustentação desta masculinidade.

Por outro lado, a relação com o avô parece ter permitido a partir de um deslocamento com a figura paterna, uma maior vinculação num investimento amoroso, falhando em parte no exercício de reposicioná-lo no lugar de exclusão, inoperante num corte na relação com a mãe (castração) que o recolocaria neste lugar de exclusão e portanto da falta, da incompletude.

Constatamos, ao nível latente, a solicitação da figura/função de um homem/mestre/pai, no sentido de ajudá-lo a administrar suas lutas internas (o domínio da luta) e portanto sua ordem de conflito.

Neste grupo referido em seu desenho, "Dragão Vermelho”, “todos teriam que se relacionar bem e só poderiam sentir raiva de inimigos de outros templos, nunca do mesmo, pois caso contrário a única saída seria a morte”, retomamos aqui o traço identificatório no grupo - no clã. Para estes discípulos, não é possível sentir medo, eles lutam pela honra, "quando sentem medo eles são imediatamente 
expulsos”, o medo e a raiva podem ser afastados e aplacados pela adoração ao totem “Dragão Vermelho” encobridora do desejo de destituí-lo.

Roberto está à procura de um mestre, cuja figura aparece representada de forma idealizada, onipotente, sustentando uma identificação com um homem todopoderoso que estabeleça a lei e não se submeta a ela, a submissão é vivenciada como morte neste momento, sem abertura para ele de possibilidades identificatórias.

Nas Lecciones Introductorias al Psicoanalisis, precisamente na $X X-L a$ Vida Sexual Humana - (1917) Freud cita Reik, a respeito de seu estudo sobre os rituais entre os povos primitivos realizados na puberdade que representam uma ressurreição, tendo por objetivo romper a ligação incestuosa que liga a criança a sua mãe e efetuar sua reconciliação com o pai. (p.2332)

Neste sentido, esta demanda de um grupo para desenvolver as artes marciais poderia representar para Roberto este ritual de passagem encaminhando-o para a tão almejada maioridade manifesta. É pela queixa, (motivo da consulta) e pela via das relações sociais que Roberto tem demandado algo desta ordem da função do pai, onde este posicionamento subjetivo, estas "lutas internas", poderão ser redimensionadas. Parece que a escola tem assumido para ele um lugar de grupo inimigo (expulsão) mas, simultaneamente, constitui-se o lugar de onde parte a demanda, onde a falta é denunciada.

A presença de um terceiro desde este lugar transferencial, na tentativa de encaminhar e negociar as operações possíveis que neste reduto mãe/filho têm permeado esta área do conflito familiar, pode se constituir como perspectiva dentro de uma proposta psicoterápica .

\section{CASO DENISE}

Frente a convocação dos pais, comparece somente a mãe para a entrevista. O motivo do encaminhamento refere-se a "dificuldades no aprendizado, especificamente na disciplina de Matemática e conflitos tanto em casa no relacionamento com a mãe, assim como com os colegas na escola” 
Denise é a filha mais velha (10 anos) tendo uma irmã (6 anos) que nasceu com uma malformação congênita ${ }^{10}$ necessitando constantemente de cuidados médicos, seja em função das cirurgias corretivas, seja devido às infecções urinárias recorrentes.

Na primeira entrevista com a mãe, esta comenta:

Denise sempre foi de bater e agredir os outros, está na $4^{a}$ série e a escola me orientou para procurar uma psicóloga em função da dificuldade em Matemática, pois não consegue decorar a tabuada, nem resolver as contas e os problemas, tem também uma letra horrível e costuma ser agressiva com os colegas, bate, não leva desaforo para casa...sempre foi levada e malvada, tipo colocar o gato no forno, brincadeira de matar, fingir que está morta... desde pequena, até nas brincadeiras, nunca aceitava ser a filha, sempre queria ser a mãe...

Em relação à família:

Estou separada desde 99, vivíamos em brigas, muitas vezes as meninas presenciavam... o pai de Denise é muito agressivo, descontrolado, andava sempre armado, tinha até coleções de armas...a decisão da separação veio a partir de um episódio onde ele me agrediu fisicamente diante das meninas, fui parar na delegacia, quase perdi a visão, ele não deveria nem mesmo pisar na calçada da nossa casa. O juiz proibiu no primeiro ano que ele pegasse as crianças, mas foi liberando aos poucos....depois desta briga não há diálogo, quando ele liga em casa só fala com a Denise e manda ela me dizer um monte de coisas, às vezes até xinga e eu mando a resposta por ela, o que precisa ser dito ela diz tudo o que peço. Teve uma vez que ele mandou uma carta e quando a Denise leu, picou e bateu no liquidificador, depois jogou na privada e deu a descarga. Quando eu perguntei porque ela tinha feito isso, respondeu: perdido por um, perdido por todos...

10 Trata-se de uma anomalia congênita, que leva a alterações do sistema urinário e da locomoção. 
Vivemos 13 anos juntos, ficamos um período sem ter filhos, até que nasceu a Denise... ele é autoritário e eu também sou, tinha que aceitar tudo o que ele falava, não podia contrariar. Hoje eu digo para as minhas filhas não pedirem nada para o pai, pois na medida do possível eu compro.

A irmã de Denise nasceu com sérios problemas de saúde, ela é dependente e exige muitos cuidados. Sempre me senti culpada pelos seus problemas, pois no início eu nem sabia que estava grávida e durante uma briga com o meu marido ele me deu um empurrão e eu caí, precisei tirar uma radiografia e só depois descobrimos que eu estava grávida. $O$ médico sempre procurou me tranqüilizar mas no fundo eu me sinto culpada. O problema dela exige muito da gente, temos que colocar a sonda diariamente... o pai nunca quis colocar ou mesmo ajudar neste sentido, mas a Denise ajuda, principalmente quando eu estou trabalhando ela cuida da irmã... quando a irmã nasceu, Denise ficou com muito ciúme, até batia em sua cabeça, mas hoje as duas são bastante unidas...

A mãe conta que o pai de Denise teve um primeiro casamento tendo três filhos (dois meninos e uma menina); durante o segundo casamento com a mãe de Denise teve paralelamente um relacionamento com uma terceira mulher chegando a ter outro filho; alega que ele sempre foi mulherengo e já nos últimos anos envolveuse com outra pessoa com quem vive até hoje.

Em relação à Denise comenta:

Desde pequena ela sempre foi muito voluntariosa, sofre de bronquite asmática e no ano passado passamos por um susto, deram na farmácia um remédio errado e ela tomou a dosagem que o médico indicou e viemos parar na UTI, foi um susto danado, mas ela diz que adorou passar pela UTI...

Comenta ainda a seu respeito: 
Vivo estressada já fui parar diversas vezes no pronto socorro com a pressão alta e sensação de morte. Não sei o que acontece... o bairro em que moramos é muito perigoso, tem muitos assaltos, até tiroteio, não deixo as meninas saírem do portão... quando elas estão sozinhas, peço para deixarem sempre as portas de casa trancadas, podem entrar e fazer uma barbaridade... sinto que meu coração dispara e aí fico apavorada, com medo de sair, não conseguindo trabalhar com os meus alunos e sentindo muita vontade de chorar... Passei pela Psiquiatria por orientação do médico do P.S. e comecei a tomar calmante....espero ficar mais calma em casa com as meninas, pois a Denise é muito agressiva, acha que é a dona do mundo, brigamos todo dia, até por pequenas coisas, assim fica difícil de suportar.

Entramos em contato com o pai de Denise convocando-o para uma entrevista, mas justificou-se quanto à impossibilidade de comparecer em função de residir fora de São Paulo. Pelo telefone manifestou uma preocupação quanto ao assunto a ser abordado, enfatizando que embora viesse quinzenalmente para São Paulo verificar o andamento de sua loja, não teria possibilidade de um agendamento em função de estar apenas de passagem.

Durante a entrevista a mãe de Denise mostra-se ansiosa, prolixa, insistindo sempre na queixa em relação ao ex-marido, no fato de não conversarem desde o período da separação. Enfatiza a violência dele na relação entre ambos, expressando uma necessidade imperiosa de seu afastamento da casa, da calçada, das filhas, garantindo do seu ponto de vista, uma proteção dentro do ambiente familiar que se configura repleto de ameaças, tiroteios.

Num primeiro momento, coloca-se de forma defensiva enfatizando o seu esforço perante a família, procurando suprir todas as demandas, num mecanismo onipotente, negador da angústia e do desamparo, lembremo-nos aqui da doença congênita da filha caçula. Progressivamente este lugar onipotente não se sustenta manifestando uma fragilidade perante o mundo externo e interno tão ameaçador. A morte se faz presente desta vez, através das inúmeras violências cujo lugar paterno tão bem personifica (suas agressões físicas, vive armado...), a presença de angústia sinaliza uma ruptura neste arranjo interno, a estrutura narcísica sofre um abalo, o 
pedido de pronto socorro não pode ser mais adiado, as mulheres da casa demandam cuidado médico.

Nas entrevistas (duas) com Denise, referindo-se ao motivo de sua vinda:

Vou mal na escola principalmente em Matemática, não entendo, não consigo decorar a tabuada, não consigo resolver os problemas... fico irritada com tudo...não tenho paciência...tenho umas amigas com quem ando mais junto na minha escola, mas às vezes acaba em tapa e aí tenho que ir para a sala da orientadora para conversar...

Mantém-se em silêncio e aos poucos vai falando sobre sua vida e família, frente a proposição de conhecê-la:

Meus pais moram separados (Por que?)... o meu pai bateu na minha mãe...ele mora em outra casa, com uma outra mulher....(Como é o relacionamento com o pai?) ...toda vez que ele liga lá em casa, briga e reclama, ele é muito nervoso, não tem muita conversa, vive mandando recado para a minha mãe $e$ também briga comigo...só eu atendo ao telefone em casa, aí num ouvido ele fica falando e eu fico repetindo em voz alta, aí a minha mãe fica reclamando e eu fico ouvindo pelo outro ouvido, até a hora que vira uma xingação e eu não sei mais quem falou o quê... com a minha irmã ele não fala desta maneira pois a minha irmã é chorona....

Referente às coisas que gosta e costuma fazer:

Assisto T.V., adoro gatos, minha mãe não quer bichos em casa, ela reclama que dá trabalho, mas aí apareceu no portão de casa um filhote, era uma gatinha, coitada. Pedi muito para minha mãe deixar eu cuidar, eu já tinha visto a mãe dela andando pelo muro de casa, acho que ela deu cria, aí jurei para a minha mãe que eu cuidaria, e aí ela acabou deixando desde que ficasse fora de casa, mas ela estava magrinha e precisamos alimentar, levar ao veterinário; agora a Pati (nome da gata) está grande e apronta mil 
coisas e a minha mãe fica brava, querendo torcer o pescoço da gata pelas "estrepulias" (risos)

Inicia a segunda entrevista com uma pergunta:

Você viu na T.V. o avião batendo contra as torres, e as pessoas caíndo?

Comenta sobre o ataque terrorista nos E.U.A., gesticulando, impressionada, sobre o choque dos aviões contra os prédios e referindo-se às mortes, expressando todo o impacto da situação .

Num segundo momento, conta com detalhes o dia em que o pai foi embora de casa, devido à briga com sua mãe:

Eu e minha irmã ficamos apavoradas, achando que ele iria matar a minha mãe... cheguei até a me ajoelhar e pedir para ele parar de bater, fiquei com muito medo, ele tava machucando ela...

No relacionamento com a mãe:

Eu sou meio teimosa porque a minha mãe fica reclamando $e$ exigindo um monte de coisas, tomar conta da minha irmã, arrumar a cama, arrumar os brinquedos quando ficam fora do lugar, quando fica bagunça...(Com quem se parece?) .... minha mãe diz que eu sou a cara do meu pai, me chama de "Chica 2", pois o meu pai, todo mundo chama de "Chicão", até os dedos da minha mão e do meu pé são iguais aos dele...(risos)

Em relação à irmã:

Ela é meio pirracenta, tudo ela chora...muitas vezes não posso sair com os meus primos ou mesmo ir para a casa do meu pai (no litoral) passar o dia, por causa da minha irmã que às vezes está internada e outras vezes não pode sair, tendo que ficar deitada....Quando os meus primos vêm em casa e resolvemos 
brincar de pega-pega, eu acabo colocando a minha irmã de cavalinho, nas costas, para que ela brinque também como todo mundo...ela tem dificuldade de andar precisa de muletas e não consegue correr...só que ela pesa...

O tema da violência está especialmente presente nesta família, que se concretiza nos ataques terroristas. Num primeiro momento a violência está circunscrita ao pai (colecionador de armas, poderoso) neste lugar onipotente que nos remete ao pai mítico da horda primitiva, dispondo arbitrariamente das mulheres e das situações conforme a sua determinação e agrado.

Configura-se um campo de batalha entre o casal, que se destaca numa medição de forças entre ambos, numa disputa fálica onde a mãe incita as filhas, tal como ela a dispensarem este pai violento (não peçam nada para o pai, deixa que eu compro...). Curiosamente este movimento inicial de abolir a violência e afastá-la da família retorna de diferentes maneiras, como por exemplo, através dos traços identificatórios de Denise com o pai (Chica 2... os mesmos dedos dos pés e das mãos). Digamos que Denise, segundo a queixa apresentada pela mãe e a escola vive armada, atacando e brigando freqüentemente. Entendemos que através deste traço representativo do lugar paterno neste grupo familiar, estabelece-se por um lado um movimento defensivo e evitativo de um maior contato com a falta, ou qualquer ordem de perda, paralelamente há uma espécie de convocação do pai através desta referida agressividade de Denise - (ela bate- com a agressividade ele se faz novamente presente).

O movimento destas três mulheres sobreviventes aos ataques terroristas desse pai é encobridor por meio dessa montagem narcísica e fálica de uma fragilidade e desamparo que pela via dos “infortúnios” (a própria doença da irmã) assume sua nova versão.

Propomos refletir sobre o lugar que Denise assume entre os intercâmbios que permeiam a relação deste casal, particularmente de porta-voz das agressões mútuas, ficando de intermediária de algo que não vislumbra conciliação, o sistema de negociação é precário fadado ao fracasso (lembremo-nos a constante xingação pelo telefone). Remetemos à conflitiva edípica para o posicionamento da criança perante $\mathrm{a}$ relação possível deste casal. Denise situa-se como elo de união (cena do telefone) intermediando a comunicação entre ambos e simultaneamente reafirmando esta 
impossibilidade. Neste contexto, reafirma-se a rivalidade com a mãe, afinal Denise é a eleita pelo pai para conversar pelo telefone (ele só fala com ela) assumindo esta intermediação também a partir de um consentimento materno. Ambos os pais, cada um a seu modo consentem neste posicionamento, desdobrando-se no tratamento entre mãe e filha de igual para igual, justificado também pela referida personalidade forte de Denise (desde pequena, nas brincadeiras ela nunca aceitava ser a filha, sempre queria ser a mãe). Expressão de traços identificatórios com as figuras parentais, pois coincide com a forma onipotente como esta mãe inicialmente se apresenta favorecendo dinamicamente a própria onipotência da filha, tendo como manifestações as correspondentes atuações agressivas com a figura materna, já referidas na queixa: campo de batalha pela disputa do objeto na triangulação edípica.

Por sua vez, Denise, ao picar a carta do pai e jogá-la na privada, expressão da raiva em relação aos objetos, assume-se num duplo sentido, ora representando a mãe raivosa com este homem, desejosa de picá-lo, ora manifestando o desejo de ocupar o lugar da mãe na relação com o pai (a carta jogada fora) afinal através da correspondência, poderia abrir-se um canal alternativo de comunicação, sendo dispensada a sua intermediação.

Com os cuidados dispensados à irmã, mais uma vez Denise é convocada para um lugar parental tendo que ajudar esta mãe na tarefa diária de colocar a sonda na irmã, condição física esta, até aqui sem vislumbre de solução. Esta ordem de violência imposta pela realidade - a doença da irmã - passa a ser diluída na sua dimensão dramática, considerando que a figura paterna rouba a cena, sintetizando toda a violência e ataques vivenciados pelo grupo familiar. De certa forma o lugar paterno presta-se a este deslocamento; com a separação coloca-se para fora o elemento ameaçador, considerando por outro lado a impossibilidade de eliminação da irmã que com a sua doença ressignifica as agressões e ataques (lembremo-nos que ela sofre as invasões cirúrgicas e das respectivas sondas diárias). O peso desta irmã doente aparece na brincadeira de pega-pega com os primos onde Denise ressente-se por ter que carregar a irmã nas costas e incluí-la para não deixá-la de fora, "sem chance”. Diante do cenário de violência atualizado pela figura do pai, a tragédia sofrida pela irmã pode ser ora negada, ora diluída a partir de outras situações ameaçadoras que a família enfrenta. 
Por meio de Denise podemos dizer que o pai se faz presente no dia-a dia, mas não o pai enquanto figura representante de uma função limitadora e portanto organizadora (castração), mas o pai que se assume como figura agressora e arbitrária, potencializando o temor e hostilidade. As explosões de Denise com a mãe e com os colegas na escola têm um sentido de convocação desta função representada pelo lugar paterno (lei), aspecto que se encontra conflituado já nas figuras parentais, afinal Denise é convocada para intermediar a relação entre o casal ao invés de ser excluída e conseqüentemente protegida no seu lugar de filha.

O elemento narcísico delineia-se na relação entre mãe e filhas, fortalecidas e defendidas num posicionamento onipotente, onde nada precisa ser pedido (não precisa pedir para o seu pai, deixa que eu compro) onde nada falta. Aspecto encobridor do desamparo que fica sinalizado na busca de um terceiro que possa intervir para aliviar o sofrimento destas três mulheres, agora sim fragilizadas: a doença da irmã de Denise que exige os cuidados médicos com seu acompanhamento e intervenções; as crises de angústia da mãe que demandam um "Pronto Socorro" e as queixas em relação a Denise que enfrenta uma dificuldade na "resolução de problemas”, nas contas e equações matemáticas, onde o resultado é empobrecedor (perdido por um, perdido por todos). A tarefa diplomática, a qual Denise é imbuída para encaminhar as "negociações” entre estes campos inimigos não tem sido capaz de evitar choques e explosões.

Surge o desamparo e a fragilidade tanto através desta irmã que necessita “ser carregada” como através das crises de asma de Denise onde também necessita ser cuidada, ou mesmo, através da referida gatinha (coitada, tão magrinha) que também necessita ser alimentada e protegida.

O espetáculo deste mundo ameaçador reaparece através das telas da mídia numa cena de desmoronamento de uma imagem fálica, poderosa - as torres, de uma sociedade representativa da máxima potência (que mais se assemelham às cenas de um filme de guerra e ficção tal como as brincadeiras com a morte que a mãe relata durante a entrevista). Pensamos que desde o lugar transferencial Denise nos convoca não só a testemunhar (você viu?) mas a promover algum tipo de resgate, neste momento em que a sustentação desta fortaleza, espaço privado dessas mulheres sofre seus profundos abalos. 
Mais uma vez o cenário público “empresta” a sua imagem para a encenação de algo que no campo privado/familiar se vê nesta nova versão humanamente representado.

\section{CASO FABINHO ${ }^{11}$}

Fabinho veio encaminhado tendo como motivo da consulta, “dificuldade na escola associada a sintomas fóbicos”.

$\mathrm{Na}$ primeira entrevista compareceram os pais, onde mencionam intensa preocupação com o filho (único) em função de seus medos:

(Mãe) Fabinho tem 9 anos e desde pequeno tem dificuldade em dormir sozinho em seu quarto, vive pedindo para dormir conosco...

Dirijo-me ao pai:

(Pai) Na realidade é uma criança medrosa, mesmo para sair na rua, não vai só até a esquina, tem que estar sempre acompanhado de um adulto... não gosta de falar sobre si, apenas para a mãe conta as coisas que lhe aconteceram com os amigos na escola.

(Mãe) Fabinho é muito sensível, dócil, não é de brigar com outros meninos... Está atualmente na $3^{a}$ série e embora consiga a média para passar de ano, as professoras comentam que ele poderia ir bem melhor, que é uma criança com potencial, mas não entendem porque nas provas o seu desempenho está sempre abaixo do que ele desenvolve durante as aulas....Fabinho não dorme fora de casa, mesmo quando vai para a casa dos avós tem que dormir na cama com eles, caso contrário não aceita ficar lá.....

11 Mantivemos o nome fictício no diminutivo, preservando a mesma forma que os pais expressaram durante toda a entrevista ao referir-se à criança. 
Casados há 16 anos, contam que houve dificuldade para engravidar recorrendo a tratamento médico:

(Mãe) ...Os espermatozóides morriam rapidamente....e eu também não queria engravidar...lembro que o meu marido chegou a falar com os meus pais, para me convencerem a ter pelo menos um filho... sempre tive medo de ser mãe e assumir o cuidado de uma criança, totalmente dependente da gente...Quando Fabinho nasceu fiquei muito mal, chorava o tempo todo achava que não daria conta....

(Pai) ... Eu perdi a minha mãe quando tinha 9 anos, até esta idade eu vivia embaixo da saia dela, foi um golpe e junto com os meus irmãos fui criado em condições precárias, muito largado....Na hora de dormir já virou rotina, coloco um colchão no chão e o Fabinho dorme na cama com a mãe e eu no colchão, não cabemos os 3 na cama, aí fico sem dormir e fico nervoso.

(Mãe)...Recentemente faleceu meu irmão mais velho, com quem Fabinho era bastante ligado e ficamos todos muito abalados... embora meu marido não quisesse a presença do Fabinho no velório, pois ele achava mais importante guardar uma boa lembrança do tio, Fabinho acabou indo por causa da minha mãe que estava inconformada... Já tentamos de tudo, mas ele chora e diz que tem medo de fantasma e de monstros...talvez tenha ligação com os desenhos que passa horas vendo na T.V., pois ele fica muito tempo em casa sem amigos e gruda na televisão...

Consta ainda que nos últimos anos, o casal tem discutido bastante chegando a cogitar a idéia de separação:

(Mãe) Atualmente estou sem trabalhar e acho que ele (marido) pensa que eu não estou querendo, mas a situação está difícil... ele vive nervoso e irritado dentro de casa, parece uma pilha...

(Pai) Eu já estou nervoso com o trabalho, os gastos e também fico irritado pela situação em casa, acho que ela (esposa) apóia demais o Fabinho, dá muita cobertura, fica um nhê-nhê-nhê... 
Durante a entrevista com os pais, constatamos do ponto de vista dinâmico um domínio da mãe durante a conversação, em nenhum momento dirige-se ao marido, colocando-se na maioria das vezes de maneira informativa, sem uma implicação propriamente afetiva ligada ao conteúdo de seu relato, exceto quando menciona o dilema de tornar-se mãe. O pai por sua vez coloca-se apenas quando solicitado, no entanto através dele aparece de fato um mal-estar diante desta situação, neste sentido fala de sua irritação e nervosismo, diante da repercussão na relação do casal, dos medos vividos pelo filho.

Na primeira entrevista com Fábio, inicialmente perguntamos se ele sabia o motivo de sua vinda:

É porque eu sinto medo.... ( De que sente medo?) ...eu assusto com qualquer barulho... (E o que acontece?)....tenho que ficar perto de outras pessoas em casa, meus pais ou alguma outra pessoa tem que ficar comigo....(O que acontece se ficar sozinho?)...Sei lá, acho que é porque eu assisti “Boneca Assassina” e não consigo parar de pensar no filme...eu quero ficar assistindo os filmes de terror, mas depois fico com medo...(Sente medo de outras coisas?)...Também tenho medo de ladrão... já assaltaram várias casas na minha rua...Também tenho medo de gente morta, de fantasma.... eu não queria ver meu tio no caixão, mas acabei vendo...ele estava feio....eu saía com ele para pescar...era legal...

Em relação à família, ao que costuma fazer:

Eu converso e saio mais com a minha mãe... às vezes saio com o meu pai.. mas eu prefiro ficar em casa , não sou de sair ...(O que faz em casa?)... Fico brincando com os meus bichinhos- Pokémons, vendo T.V., jogando vídeo-game...não gosto quando meus pais brigam...tenho medo deles se separarem....

Referente à escola: 
Tenho alguns amigos, mas eu não gosto de ir à casa deles.....no recreio até que a gente brinca com os Pokémons....eu não gosto de ter que fazer prova...mas a professora é legal.... pessoal da escola me chama de Binho (Por que Binho?)....eu não sei todo mundo tem apelido... lá em casa meu pai me chama de nhê-nhê-nhê, aí eu chamo ele também de nhê-nhê-nhê e a gente fica brincando....

Diante da solicitação de um desenho livre, Fabinho desenha uma casa e relata a meu pedido, a seguinte estória:

Nesta casa, mora uma criança... (Conta alguma coisa sobre esta criança?)...É uma menina que está de castigo, ela `as vezes se sente muito sozinha, mas os pais proibiram ela de sair. (Por que está de castigo?)... Os pais ainda não falaram para ela porque está de castigo....(Por que ela acha que está de castigo?)....ela não lembra o que fez....

Fabinho pega na caixa lúdica um material de madeira de encaixe e constrói o que ele denomina de uma nave (grande) e um detonador (pequeno), pega os soldados e diz:

...Aqui é um campo de batalha, e tem este detonador que quer explodir o foguete dos inimigos que querem roubar tudo deles....

Durante a maior parte desta entrevista Fábinho mantém-se na encenação deste combate, limita-se a responder às perguntas e solicitações sem maiores comentários por iniciativa própria. Ao mencionar seus medos ou algo relativo aos pais, sua fala é infantilizada, diminui o tom de voz, abaixa a cabeça.

Através destes dados, relativos às primeiras entrevistas, ressaltaremos o lugar do pai neste grupo familiar e como esta dinâmica articula-se à queixa apresentada.

Contextualizado a partir da conflitiva edípica, temos o filho ao lado da mãe e o pai como terceiro excluído, a cena do horário de dormir mostra com nitidez a distribuição dos lugares nesta família. Fábio que na fala dos pais é Fabinho, está 
externa e internamente impedido de crescer, aspecto que por motivos diferentes satisfaz a seu modo, cada um destes "atores”.

Em relação à mãe temos, por um lado, este filho sempre presente (na cama, à noite...), oferece-se como objeto fálico, encobridor das questões geradoras de conflito entre o casal , do mal-estar nesta relação, que do ponto de vista narcísico tem se apresentado como obstáculo para um novo encaminhamento, impedindo a inclusão deste pai como ordenador de um lugar menos onipotente para o filho exercício necessário para uma efetivação da castração; por outro lado, a ambigüidade desta mãe quanto a assumir este lugar materno (lembremo-nos o medo de engravidar, de ter um filho, acreditando que não daria conta...), configura o excesso de proteção com a criança num mecanismo de formação reativa frente a hostilidade que, ao contrariá-la, o filho desperta (menciona: não queria engravidar...meu marido buscou a influência dos meus pais para me convencer.... fiquei muito mal quando Fabinho nasceu...)

Temos a figura de um pai, que embora desejoso de ter um filho, consta que “os espermatozóides morriam” não chegavam ao seu destino (foi necessário um tratamento para engravidar) observamos que este homem também desfalece (literalmente vai para o chão) neste meio de caminho para chegar ao seu posicionamento na triangulação edípica que o sustente na sua função. Identificado com o filho, que não suportaria ficar sem a mãe (lembremo-nos da associação durante a entrevista, relativa à perda de sua mãe quando tinha nove anos, a mesma idade de Fabinho) este pai vê-se diante do filho num processo elaborativo de suas próprias questões relativas aos seus pais (associa: vivia embaixo da saia de minha mãe...). Assim como Fabinho, ocupava um lugar ilícito; confrontado com a morte desta mãe, restam a angústia e o desamparo, ficando de acordo com suas palavras largado. Paradoxalmente, esta mesma situação o coloca diante de seu desfalecimento e desamparo, repete a situação de uma mulher que o abandona e o deixa desprotegido, largado no chão.

Do mesmo modo que para engravidar a esposa, necessitou de tratamento, também neste momento, gerador do posicionamento de Fabinho perante os objetos e o mundo, esse pai não encontra vitalidade para ocupar o seu lugar e exercer sua função limitadora diante da aliança narcísica entre mãe e filho, demandando alguma sustentação perante sua própria dinâmica, na qual enquanto pai, prevalece numa posição desfalecida. 
Fábio por sua vez, dá continuidade por diferentes vias ao narcisismo parental, sendo a criança super protegida (que não vai até a esquina só) neste lugar eu ideal (Fabinho) não tendo que se enfrentar com a morte, com a exclusão, em suma com a própria castração, aspectos que seriam resultantes do exercício da função do pai.

O quadro sintomático de caráter fóbico (medo de barulhos, fantasmas, monstros, assaltos e de ficar só) e inibitório (preferir ficar em casa, brincando só e comprometimento de sua produtividade escolar nas provas) aponta para o lugar em que Fabinho se encontra basicamente dominado pelo complexo de Édipo. Ocorre uma projeção para o meio externo de sua agressividade e hostilidade em relação à figura paterna. O desejo no jogo edípico de triunfar sobre o pai, eliminando-o e ganhar a mãe para si, é nesta família diariamente reafirmado. Suprimir este pai remete-nos ao impulso assassino da conflitiva edípica, conteúdo este, que tal como Hamlet, transfigura-se num fantasma/pai a persegui-lo e atormentá-lo. Chama-nos atenção o filme de terror que ele nos diz querer tanto assistir, embora o deixe com muito medo - Boneca Assassina, trazendo à tona os elementos identificatórios que o subtraem de sua virilidade.

Segundo as palavras da mãe, Fabinho é sensível, chora com facilidade, sugerindo uma fragilidade que necessita ser amparada, aspecto este encobridor de um autoritarismo ao qual os pais, como reféns, estão inteiramente submetidos e assim, toda noite a família está submetida ao ritual imposto pelo filho, que ao estilo de um assaltante invade o quarto dos pais, condenando este pai a ir para o chão, marcando de maneira triunfante seu lugar no território materno.

Em Inhibicio, Sintoma y Angustia (1926) Freud ressalta que o impulso recalcado é justamente o impulso hostil contra o pai, ficando recalcado pelo processo de transformação em seu contrário, assim no lugar da agressão contra o pai surge a agressão - a vingança - do pai contra o sujeito.

Nesta batalha que no jogo lúdico é claramente encenada, ou seja, a nave/grande está aliada ao detonador/pequeno que por sua vez, ameaça a qualquer momento em caso de invasão e ataque, destruir o foguete/grande, inimigo mortal. Estes diferentes lugares nave/detonador/foguete assumem posições intercambiáveis, ou seja, no momento do triunfo de Fabinho sobre o pai, na sua onipotência ele passa para o lugar de foguete/poderoso/invasor, mas que se angustia frente ao detonador/pequeno em que o pai se transforma, configura-se aqui nesta trama a 
angústia de castração, que pela via do recalque e do deslocamento, encontra sua singular manifestação no quadro sintomático.

Do ponto de vista do mecanismo de identificação pela via regressiva, Fabinho apresenta traços de identificação com a figura materna que o sustenta narcisicamente em um lugar especial de difícil renúncia, aspecto que o infantiliza e o remete a uma posição feminina, camuflada na criança sensível e frágil (nhê-nhê-nhê) lembramos o material projetivo no desenho da casa e a estória da menina impossibilitada de sair. Os traços identificatórios com a figura paterna, por um lado, satisfazem este pai narcisicamente (ambos são o nhê-nhê-nhê da mamãe) e, por outro lado, com a sua hostilidade e rivalidade, Fabinho sustenta o triunfo frente à conquista do objeto.

Mas os fantasmas têm feito ruídos naquela casa, Fabinho está no meio do casal parental, testemunha dos inúmeros choques entre ambos, teme pelas brigas entre os pais. Orientado pelo desejo e pelos afetos amorosos e hostis dirigidos aos pais, mergulhado em sua onipotência infantil, Fabinho coloca-se como elemento central na responsabilidade sobre os desentendimentos entre o casal e fica assustado, atribuindo-se um potencial detonador que o amedronta. Do ponto de vista do supereu, instância paterna a condená-lo, há uma criança/menina que tem que permanecer de castigo, pois fez algo errado que não pode ser verbalizado nem por ela nem pelos pais, mas que a impede de sair; precisamente via sentimentos punitivos e de culpa, dá-se o impedimento da saída de Fabinho deste quadro de inibição e de medos. Assaltantes e monstros têm rondado este cenário encontrando-se a espreita para eventuais ataques, fazendo com que Fabinho sinta-se muito ameaçado.

Transferencialmente Fabinho apresenta-se em alguns momentos bastante fragilizado e neste sentido "propõe" que tal como os pais, vejamo-no nhê-nhê-nhê, absolutamente sem recursos internos. No entanto, na busca do atendimento, o malestar familiar tem demandado uma intervenção, na tentativa de uma recolocação dos devidos lugares, neste sentido a recuperação deste pai desvitalizado sugere ser fundamental. Parece inevitável o risco que esta demanda configura, onde eventualmente, possamos nos transformar num inimigo/monstro/assaltante que vai invadir esta casa e levá-los ao confronto com inevitáveis perdas (lembremo-nos que a morte recente do tio querido tem a sua contribuição no aumento da angústia que em ultima instância é para Freud, angústia de castração). 
Neste sentido, as negociações são delicadas à medida que esses laços familiares, embora abalados, sustentam uma aliança e complementariedade. Os sintomas de Fabinho sinalizam para esta ordem de problemática que, do ponto de vista do lugar paterno e sua função, requerem frente ao referido mal-estar a emergência de um redirecionamento.

\section{CASO LUCIANA}

Luciana tem 11 anos, está na $5^{\mathrm{a}}$ série e veio encaminhada com a seguinte queixa: “desinteresse pelos estudos, desobediência e alimentação compulsiva” (obesidade).

A primeira entrevista foi realizada com os pais:

(Mãe) Foi a orientadora da escola que achou melhor fazer uma avaliação psicológica, pois apesar da Luciana ser no fundo uma boa menina, ela vive bagunçando, não presta atenção, não está nem aí para os estudos; como ela é muito inteligente acaba conseguindo passar de ano, mas é sempre um sufoco, fica de recuperação. A Lú é filha única e todas as atenções são para ela....Acho que a situação da escola está piorando a cada ano, ela fica fazendo parte da turma que não estuda, ela sempre procura as amizades que não são as melhores....Em casa eu converso com ela, mas também brigo, como eu trabalho muito, é difícil acompanhá-la durante a semana, ela acaba ficando em casa com o pai que está sem emprego, não está trabalhando, mas ela não respeita o pai... Mente, diz que está estudando, só que enrola, chama as amigas para estudar, diz que tem que fazer este trabalho, mas este trabalho não sai....

Dirijo-me ao pai para saber a opinião dele:

(Pai) Acho que é assim deste jeito como ela tá falando....(silêncio olha para a esposa) 
(Mãe) Eu sou enfermeira chefe e trabalho em dois hospitais, sabe como é, não é fácil sustentar uma casa, ajudo até a minha família que sempre enfrentou problemas financeiros, tanto meus pais como minhas irmãs, eu acabo tendo que segurar essa também, mas como meu marido está desocupado, ele ajuda em casa com a Luciana...no início deste ano ele entrou no Supletivo porque eu insisti muito,fiz questão de pagar, acho que ajuda na hora de arrumar emprego; hoje em dia, quem não estuda, quem não tem pelo menos o $1^{\circ}$ grau completo, como é o caso dele, não tem chance....foi difícil para ele recomeçar a estudar...

Dirijo-me novamente ao pai para ouvi-lo:

(Pai) Não é tranqüilo, é ruim...mas minha mulher acha que eu tenho que estudá primeiro para arrumá trabalho, porque tá difícil, sem chance...(silêncio)

(Mãe) Ele desanima, mas eu insisto....eu mostro para ele que eu só tenho trabalho porque batalhei muito, meus pais também não tinham condição de pagar estudo, foi uma luta.... às vezes fico cansada, mas tudo depende de mim...A Luciana também tem outro probleminha, come sem parar, ela engordou bastante, come sem controle, até já perdeu roupa...eu sei que no fundo incomoda, que ela se compara com as amigas, mas parece que ela não dá bola...ela já está acima do peso, mas não segue a dieta que a pediatra propôs...também fico com dó de recusar comida, tanto eu como o pai, já passamos até fome quando crianças, fico com dó de recusar comida, coitada, não consigo negar quando ela pede....

Olho para o pai:

(Pai) Ela come o dia todo, eu vejo em casa, falo pra ela pará....mas ela come até escondido....(Olha para a esposa) 
(Mãe) Eu digo para ele controlar esta parte, mas acho que ele também fica mole com a filha....não consegue recusar doce e ela aproveita.....faz o que quer.....

Em relação ao casal, observamos que nesta entrevista, assim como na dinâmica entre ambos, o comando está com a mãe, o pai assume um posicionamento periférico, encontrando-se diminuído perante a sua esposa, tão auto-suficiente e provedora da família que por sua vez assume-se num lugar fálico. Os comentários provenientes do pai somente ocorrem quando é diretamente solicitado, sendo que mesmo assim, limita-se a confirmar e repetir as opiniões desta mulher que tem um domínio absoluto sobre todos.

Nos poucos momentos em que este pai se manifesta, ressaltamos um malestar (quando nos diz: não é tranqüilo ...é ruim...sem chance...) que do ponto de vista latente resulta em certa ambigüidade, ao iniciar esta frase com uma negativa (Não é tranqüilo). Partindo da referência que para a instância inconsciente regulada pelo princípio do prazer e energia livre, temos a ausência de negação, neste sentido o que pode ser desprazeroso para uma instância pode justamente ser prazeroso para outra, aspecto que se justifica pela complementaridade entre ambos. Assim, resulta que dinamicamente no contato com esse casal e na sua colocação, constatamos o enfraquecimento proveniente do lugar paterno.

Na primeira entrevista com Luciana, ao retomarmos o motivo de sua vinda, seguem os seus comentários:

È por causa da escola... minha mãe quer que eu fique o dia todo estudando...ela acha que estudar é assim, ela fica pressionando...não pode nem parar para comer...ela pega no meu pé, mas eu nunca repeti de ano... eu consigo ter média para passar... 
Continuando sobre o relacionamento com os pais:

Eu e minha mãe discutimos, mas eu acho ela legal, tenho o maior orgulho...ela conseguiu muita coisa na vida... Do meu pai eu tenho raiva, porque ele não trabalha e deixa tudo nas costas da minha mãe...ele estudou até a $5^{a}$ série e aí precisou parar de estudar...Minha mãe enfrentou a maior barra... acho que meu pai poderia trabalhar e não deixar a minha mãe com o peso de tudo....quando eu vejo ele em casa assistindo T.V. ou lavando louça, me dá raiva dele e qualquer coisinha que ele diz, a gente vive discutindo... Às vezes meus pais brigam... ela diz que tá cansada, que ele não faz nada, uma vez ela me contou que quando eu era pequena eles tinham pensado em se separar, mas por minha causa não se separaram...Tem vezes que minha mãe diz que não agüenta mais e que quer se separar do meu pai, ela diz que tá cansada, aí eu digo que talvez seja melhor, aí ela diz: e embaixo de qual ponte você vai visitar o seu pai?...Diz que não vale a pena separar porque ela ainda vai ter que pagar pensão para ele....

Sobre os amigos, lazer:

Eu adoro conversar e ficar com o meu grupo de amigas rindo, fofocando; a gente briga, mas uma vive procurando a outra ...minha mãe implica com elas, acha que eu deveria andar com gente melhor, quer dizer, que tire boas notas, porque todo mundo fica de recuperação... mas eu me esforço, mesmo quando eu tiro nota melhor ela acha que eu tenho que estudar mais... acho que ela quer que eu seja uma mini Ângela...tirando dez em tudo... Até que eu sou mesmo meio parecida com a minha mãe, porque lá na escola, todo mundo que tem problema vem pedir ajuda para mim e eu fico ajudando na hora de fazer trabalho... e meu grupo não faz nada e eu acabo fazendo sozinha. 
Num segundo momento, menciona sobre a comida e seus impasses com os pais:

....Minha mãe reclama que eu tô comendo muito e eu engordei mesmo, sei lá...dá vontade de comer doce sem parar,e aí não consigo parar...Ontem minha mãe até tirou da minha mão o pacote de bolachas, mas aí chegou uma hora que ela conversou com o meu pai e disse que ela ficava com dó de mim, era só para não comer muito, mas até que pode comer uma ou duas e aí eles me deram o pacote...A família da minha mãe tem tendência a engordar, tem uma prima que está enorme, coitada...eu não queria ficar assim...

Durante a primeira entrevista, Luciana estabelece um bom contato, colocase com desenvoltura diante das perguntas sobre sua vinda e relacionamento familiar. Assemelha-se à mãe na sua prolixidade e domínio do assunto, assim como das suas colocações no que diz respeito ao modo de ser deste pai que tanto desagrada a ambas. Esta aliança entre mãe e filha sofre um abalo com o posicionamento de Luciana frente aos estudos (seu desinteresse) principalmente por esta via estabelecese uma contrariedade dentro deste relacionamento. Luciana não segue rigorosamente a mesma trajetória materna no seu esforço para alcançar esta posição de vencedora, “desviando-se” para a trilha paterna que não se esforça, necessitando de recuperação.

Dinamicamente, este pai encontra-se no lugar de ser cuidado e suportado por estas mulheres, sendo motivo constante de desagrado e irritação. Sua posição parece ser a de um empregado na casa a servi-las. Neste sentido, mãe e filha identificam-se num posicionamento fálico, ficando para o pai este lugar fragilizado, da ordem da incapacidade, aspecto que o coloca como um "zero à esquerda", sem lugar, literalmente debaixo da ponte.

Clinicamemte, podemos pensar que através da queixa apresentada algo escapa neste “equilíbrio”, fazendo emergir um mal-estar dentro desta família. É sobre o desinteresse pelo estudo que surge o fantasma da herança paterna onde através de um traço identificatório, este pai passa a ser convocado. Luciana vai mal nos estudos, assim como o pai que é “forçado” a retomá-los (Supletivo). A figura paterna 
praticamente sem voz, encontra-se “despreparada” para exercer a sua função e sustentar o seu lugar (lembramos: na falta de emprego, assiste T.V. e lava louça); o que por um lado parece ser ruim por deixá-lo inoperante, por outro lado, algo de satisfatório esta posição preserva, colocando-se como mais um filho a ser cuidado por esta mãe poderosa que sustenta toda a família e “dois estudantes” em casa, em constante recuperação.

Assim, no "estudo", encontra-se o catalizador das questões conflitivas desta família. Luciana parece ter se enganchado nesta problemática, repetindo de forma sintomática algo que a ultrapassa, mas que também possibilita desnudar as falhas e principalmente um terreno de desamparo que necessita ser banido da história familiar.

O comentário a respeito das suas amizades (andar com pessoas que não são as melhores) sugere também uma tentativa de aproximação com a figura paterna, que no contexto familiar configura-se tão difícil, pois também este homem sem estudo pertence à classe de pessoas que não são as melhores, segundo a lógica materna. Assim se esse pai passar a ter voz e se destacar neste cenário familiar, inevitavelmente a onipotência materna passará a ser questionada e conseqüentemente o abalo desta estrutura fálica implicará num maior contato com o desamparo, ferindo esta fortaleza narcísica. Temos assim, ambas as figuras parentais confrontadas e desafiadas nos seus respectivos lugares e funções, deste modo a mãe como exemplo de esforço e luta, não admitindo qualquer ordem de fragilidade ou necessidade. Do ponto de vista narcísico, da instância do $e u$, ela apresenta-se poderosa, autosuficiente e do supereu exigente e implacável, paralelamente sua condição nos relacionamentos, no estabelecimento da alteridade, mostra-se precária, pois somente pode ter ao seu lado uma mini-Ângela ou um empregado (em outras palavras, membro das classes inferiores) para servi-la, condição necessária para dar sustentação ao seu reinado.

Luciana até certo ponto oferece-se para dar continuidade ao projeto narcísico desta mãe (tem tudo para ser vencedora), com seus traços identificatórios apoiados também numa auto-imagem poderosa, ego ideal exemplificado nestas passagens, tais como: passar de ano mesmo sem esforço... os amigos que necessitam de sua ajuda... ser a responsável pela união do casal... não ser confrontada com os limites, coitada, a dieta da qual ela tem que ser poupada. Assim, a necessidade de comer a toda hora, sugerindo uma manifestação de ansiedade que também se apóia 
de forma sintomática neste confronto com a sua onipotência, demanda algo da função do pai que no exercício da castração reordene estas medidas e delimite as suas possibilidades. Afinal, lembrando seu comentário sobre a prima enorme, temendo transformar-se nesta figura "grandiosa” fala de seu desamparo, convocando este pai, um terceiro, enquanto figura operante frente a urgência de um novo direcionamento para esta conflitiva até o momento desmedida. 


\subsubsection{Articulação do lugar e da função do pai: sua importância no cenário das manifestações clínicas}

“...De um padre que no está ahí no puede temerse la castración.”

Assim Freud se coloca em "Inhibicion, Sintoma y Angustia” (1926) para explicar a formação do objeto fóbico, onde o medo da castração se dirige a um objeto distinto e toma uma expressão disfarçada, apontando justamente para o deslocamento. Exemplificado em seus casos clínicos, respectivamente: “Juanito" (1909) - com o seu temor de ser mordido por um cavalo (objeto de deslocamento da figura paterna) ou mesmo o caso do "Hombre de los Lobos" (1918) cujo medo era de ser devorado por um lobo em lugar de ser castrado pelo pai - considera deste modo, que esta formação substituta permite entre outras coisas que a angústia da fobia seja condicional à presença do objeto e, portanto, a criança se isenta de estar diretamente ligada ao corpo a corpo com o pai, já que ela não pode simplesmente suprimi-lo. (p.2856)

Esta citação freudiana, nos permiti fazendo um desdobramento deste raciocínio considerar a sua transposição para o material clínico ilustrativo deste estudo. Nossa hipótese inicial é que os respectivos pais “estão aí”, embora caibam algumas ressalvas ao refletirmos sobre a precariedade de suas posições sinalizada em alguns dos casos e momentos da entrevista. Entendemos que este questionamento seja próprio de um pensar clínico, intrínseco às sessões preliminares, considerando que o lugar na transferência, o qual o paciente nos outorga, poderá auxiliar-nos neste diferencial. De maneira global, nos recortes clínicos apresentados neste estudo, há indícios de recursos internos nessas crianças, manifestados tanto na qualidade da comunicação estabelecida, como no contato inicial preservado, possibilitador numa primeira instância de um campo de vinculação. Particularmente nos casos Roberto e Fabinho surge uma preocupação maior quanto ao delineamento do lugar paterno, seja para Roberto pelo posicionamento desafiador/ transgressor (eu faço o que eu quero) e seu pai/traste que "de nada serve”, colocando-se num posicionamento defensivo neste primeiro momento, sem receptividade para eventuais trocas; seja para Fabinho onde seus conteúdos internos invadem a sua relação com o mundo, desencadeando o quadro inibitório, fóbico e regressivo, concomitante a um pai/desfalecido que não tem conseguido conter a onipotência da vivência subjetiva de seu filho. 
Questionamos fundamentalmente as formas de presença do pai, as vicissitudes na sustentação de sua função e conseqüentemente seu enlace nas manifestações subjetivas destas crianças. Entendemos que a ordem de dificuldade que aqui se trata é de fazer valer esta função, implicando em seu fundamento em proporcionar um diferencial de lugares, aspecto assegurador de uma circulação no social, tendo em vista que autoriza a passagem de um lugar a outro. Propomos pensar que a convocação do pai se manifesta pela via do deslocamento, através dos sintomas demandando este representante da lei, que no seu exercício efetue um corte nesta relação dual da criança com a mãe, efetivando a castração, favorecendo seu crescimento interno, abrindo possibilidade no mundo social de encaminhar os investimentos libidinais e as relações de forma suportável. Deparamo-nos aqui com a questão da patologia dimensionada por Freud, tratada por ele como uma questão de grau e neste sentido, lidando essencialmente com o fator humano, suas vicissitudes, seus contratempos.

Embora a questão diagnóstica dentro da Psicanálise (alvo de acentuadas controvérsias) se estabeleça a partir do diferencial das três grandes estruturas, sejam elas: neurótica, psicótica e perversa, trabalharemos neste capítulo, no eixo das manifestações sintomáticas, visando a sua articulação com o complexo paterno, respectivamente apoiado nos percalços da conflitiva edípica. Nosso propósito é de caráter ilustrativo em relação ao pensamento conceitual freudiano, no sentido de enfatizar a importância deste referencial como instrumento de trabalho já na elaboração das hipóteses diagnósticas desde seu momento inicial - do motivo da consulta às primeiras entrevistas. Queremos sublinhar o alcance operatório da questão edípica que passa fundamentalmente pelo lugar do pai com todas as ambigüidades que este campo comporta. Assim expressões como "pai ausente/ pai presente”, serão aqui revertidas para o campo da realidade psíquica, independentemente se o pai da criança está ou não residindo com a família. Consideramos que estabelecer paralelamente comentários sobre a clínica freudiana pode nos ser útil neste nosso propósito. 
Em Freud, vemos em todos os grandes casos clínicos - histeria (Dora, 1905), paranóia (Schreber, 1911), neurose obsessiva (El Hombre de las Ratas, 1909), fobia (Juanito, 1909) e mesmo no rico caso, alvo de controvérsias diagnósticas ( $E l$ Hombre de los Lobos, 1918), conflitos dos pacientes com seus pais, ressaltando os aspectos dinâmicos da relação com esta figura manifestados nos sintomas, demandando por parte do sujeito, uma espécie de reconhecimento.

A teorização de base em que dá origem à psicanálise parte da clínica da histeria, onde interessa-nos aqui particularmente no caso Dora (1905) apontar para a sua intensa ligação afetiva com o pai, sublinhando particularmente a identificação incidindo sobre o sintoma, o qual por sua vez reproduz um traço da figura amada (a tosse do pai) onde por regressão substitui a escolha de objeto.

A importância deste mecanismo nas manifestações sintomáticas, auxilianos, hoje, no raciocínio clínico na busca de sentido dos sintomas. Assim, vemos em Denize este traço regressivo de identificação com a figura paterna, inscrito até no seu físico, anunciado pelo olhar materno, testemunho da presença do pai na família.

Sublinharemos, ainda, dentro da dinâmica de Denise um outro aspecto referente ao lugar ocupado pelos chamados “oprimidos”, representado pelo fato destes poderem ficar afetivamente ligados aos seus opressores e apesar de sua hostilidade, ver nestes, seu ideal.

Freud já mencionara a transformação da atitude passiva em ativa, ao referirse em “Mas Allá Del Princípio Del Placer” (1920) ao fato da criança converter em jogo, um acontecimento desagradável; acrescenta ainda o fator de repetição nos jogos infantis, referindo-se a todas as situações que tenham sido causa de uma intensa impressão para a criança, procurando, assim, se desfazer desta situação, de sua carga afetiva, passando a posição de domínio sobre o fato ocorrido. Nesta mudança de posição (dentro do jogo ou das relações) de passiva para ativa, a criança faz o outro sofrer a sensação desagradável por ela experimentada, vingando-se assim nesta pessoa do que lhe foi infligido; lembremo-nos dos comentários da mãe de Denise referindo-se à sua filha quando era pequena, descrevendo as suas "malvadezas": o gato no forno, brincadeiras de morte e a constante agressividade em relação aos colegas. Cabe aqui observar que no relato tanto da mãe como da criança, as brigas e agressões físicas ocorridas entre o casal parental, eram 
sistematicamente presenciadas pelas filhas, referimo-nos a este testemunho como representativo da violência e agressividade dentro do contexto familiar.

Vemos na diversidade destes processos, que não são em si excludentes, uma articulação com a referida agressividade de Denise, apresentada como motivo da consulta. Desta forma, o pai como protagonista da violência e da agressividade, dá a sua contribuição, dentre os mais variados traços na respectiva constituição subjetiva da criança e suas correspondentes manifestações.

A partir da questão edípica, o posicionamento ativo/agressivo sustentado por Denise nas relações, nos remete também a um elemento fundamental da sexualidade feminina trabalhado por Freud, referente ao complexo de castração na menina, especificamente a inveja do pênis, podendo permanecer segundo suas reflexões no caráter, por exemplo através de um complexo de masculinidade, ou na própria manifestação dos sintomas neuróticos. Quando esta questão da agressividade de Denise, passa a ser amplificada e dimensionada para o grupo familiar, vista a partir do referencial fálico e portanto narcísico, permite-nos sublinhar a dinâmica defensiva que a violência assume para esta família, encobridora da contingência de desamparo que a doença da irmã expõe. A própria recusa do pai em comparecer à entrevista alegando sua condição “de passagem” pela cidade, aponta para um dos aspectos de ameaça que este confronto supõe.

Evidenciando seu ponto de articulação com a conflitiva edípica, podemos ainda situar uma das características fundamentais do sintoma histérico, ao considerarmos o seu elemento de transação entre a necessidade de satisfação e a de castigo, que no caso Fabinho e no caso Luciana encontram-se marcadamente delineados, ambos cumprem as suas penas, sejam elas, para Fabinho, sentindo-se constantemente ameaçado e assustado, tendo que sofrer uma restrição (não sair, nem dormir fora, nem ficar só...), seja para Luciana pela via da alimentação que não podendo ser contida “cria” uma ameaça em seu corpo que pode ficar desmedido e disforme (medo de ficar enorme como a prima)

Encontra-se um importante substrato da teoria freudiana frente a questão paterna, ao abordarmos os diferentes casos clínicos, desde o “Hombre de las Ratas”, sendo destacado por Freud o pivô da neurose, encontrando-o no “ódio infantil contra o pai”, detendo-se na ambivalência em relação à figura paterna, onde nesta modalidade do complexo paterno, o ódio inconsciente é primário e a intensificação do amor pelo pai configura-se como uma compensação reativa. Ao recalcamento 
deste ódio corresponderia a raiz das diversas manifestações obsessivas, mais tarde dinamicamente situado, do ponto de vista intra-psíquico na relação com o supereu. Diferentemente configura-se o complexo paterno no "Hombre de los Lobos", onde Freud se detém na análise da disposição passiva inconsciente em relação ao pai, sendo assim a hostilidade neste caso mobilizada a partir de outro ponto, ou seja, defensivamente contra o desejo homossexual inconsciente.(Menezes, 1992)

Na paranóia, o centro do delírio de Schreber está também colocado na figura do pai, metamorfoseada na figura do médico, em Deus e no Sol, num misto de veneração e rebeldia, como prolongamentos da atitude frente ao pai, situando em sua base a repressão da libido homossexual, eixo elaborativo para o conceito de narcisismo. Neste caso ainda, Freud destaca com profundidade o mecanismo de projeção, subsidiando com este conceito as suas reflexões e análise sobre a Cultura e a Religião.

Respectivamente com "Juanito" (1909) que manifestava inicialmente sintomas de angústia evoluindo para um quadro fóbico, permite situar o conflito edipiano na raiz da fobia, evoluindo para a consideração deste complexo como nuclear das neuroses. Este caso permite também a comprovação de suas teses sobre a sexualidade e curiosidade infantil. A “perturbação nervosa” sofrida por Juanito é entendida por Freud como uma sobre-excitação desta criança devido aos mimos da mãe que ele reivindicava constantemente para ir dormir. Conclui assim, o autor, que esta intensificação da ternura com a mãe se converte em angústia, sucumbindo ao recalcamento, angústia esta decorrente de um desejo erótico recalcado frente a um pai que se encontrava ausente, assim, Juanito dirige toda a sua libido para a mãe, ocorrendo a transformação desta libido em angústia, que neste caso, encontrará mais tarde um objeto substituto/fóbico.

Ao retomarmos esta clínica freudiana em “Juanito" é inevitável estabelecermos uma relação comparativa com o caso Fabinho, onde a angústia e seus medos aludem a esta problemática edípica. Particularmente em Fabinho, o objeto fóbico não chega a constituir-se, permanecendo um temor menos focado, que mais se aproxima de um estado de angústia despertada em condições específicas, como “estar só” . Freud trata o medo de sair como o medo de ceder aos desejos eróticos, da mesma forma o medo de ficar só, como uma evitação à tentação da masturbação solitária, que por sua vez, suscita o perigo da castração, daí a necessidade em ambos 
os casos de estar sempre acompanhado, evitando deste modo, o contato com esta angústia.

Há ainda uma ressalva importante de Freud em relação ao posicionamento materno diante dos impasses da triangulação, assim se referindo em "Inhibicion, Sintoma e Angustia” (1926):

“El mimo del niño pequeño tiene la indeseable consequencia de hacerle poner por encima de todos los demás peligros el de la pérdida del objeto - del objeto como proteción contra todas las situaciones de desamparo -. Favorece, por tanto, a la permanência en la infância, a la qual es propria el desamparo, tanto moral como psiquico” . (p.2880)

Neste sentido o posicionamento materno é de caráter crucial nas manifestações regressivas da criança, na vivência subjetiva da perda do objeto, mais tarde representada pela perda do amor ao objeto.

Do ponto de vista narcísico, a mãe coloca-se com o filho a partir de uma relação idealizada com seu pai; importa-nos também considerar o irmão da mãe (como figura substituta) lembrando que a palavra tio, etimologicamente refere-se àquele que poderia ter sido pai. No caso Fabinho, não podemos esquecer a morte do tio materno, a situação discutida na família referente à sua presença no velório (ou seja, colocá-lo ou não em contato com a morte) e sua forte ligação com esta figura, potencializando a partir deste falecimento, os sintomas fóbicos e principalmente o seu pensamento onipotente/mágico, capaz de na sua lógica, danificar, detonar os rivais. Em “Totem e Tabu” (1912) Freud já destacara o tema do temor aos mortos como área de projeção e deslocamento da hostilidade, daí a intensificação do quadro sintomático onde, da encenação ritualística noturna protagonizada pelo pai que "cai” desfalecido, agora encontra-se sua reedição, através do substituto tio, na dura realidade da qual Fabinho não tem qualquer domínio ou controle.

Enfatizamos que ao falarmos do pai, invariavelmente estamos falando da mãe, também de seu lugar e função, pois é ela que imprime a condição de dar entrada e lugar para este pai perante a criança, a partir de uma condição estruturada pelo seu desejo. 
Ainda de forma ilustrativa, como referência para situarmos a importância da constelação materna, citamos a mãe de Roberto e a ligação intensa com seu próprio pai (a figura do avô de Roberto) onde na entrevista refere-se à interferência deste na relação com o seu marido (por sinal, 27 anos mais velho do que ela) e a referida felicidade do avô se tivesse podido presenciar o fato de mãe e filho terem se livrado “daquele traste”.

A questão da constelação paterna não é menos importante, assim a relação do pai perante a sua própria conflitiva edípica, vai se situar na base da sua possibilidade de colocar-se como pai. Mayer (1983) refere que “o indivíduo somente pode constituir-se como masculino quando descobre que o pai é filho de outro pai, que ele não possui prerrogativas, que ele tem suas fraquezas, suas limitações, isto que nós teorizamos como castração” (p.106)

Vemos em Roberto a impossibilidade interna de resgatar o pai de sua condição precária, destituindo-o no manifesto de seu lugar, expressão de ódio e ressentimento com esta figura, afinal em sua versão, a criança só vale quando está com a mãe, só vale a mãe, não esquecendo o referido desejo de seu pai por uma menina e o seu correspondente temor do filho virar gay. Simultaneamente convoca-o ao longo de sua vida, seja através de sua forte relação com o avô, assim como no meio social, onde vai configurando numa cadeia associativa e substitutiva o confronto com o guarda da escola, o professor, a orientadora educacional, a diretora, o vice-diretor, a autoridade médica/psicológica, demandando por último um mestre japonês das artes marciais.

Entendemos que particularmente neste momento de passagem, representado para Roberto, tanto na sua puberdade como também na convivência com o grupo de amigos "mais velhos", confronta-se com a solicitação de ter que dirigir seus investimentos libidinais aos objetos fora do meio familiar, constituindo-se este transbordamento pulsional, como uma fonte de ameaça interna, frente a este segundo momento de escolhas objetais, reeditando as questões edípicas, agora num sentido exogâmico. 
Costa (2000) refletindo sobre o lugar paterno em Freud, com clareza retrata a ambigüidade que lhe é intrínseca, pois por um lado comporta este ser legislativo, motor das identificações, passagem à cultura, por outro sintetiza a dimensão patologizante. Assim observa duas condições que são interdependentes para Freud como forma de amparo social, respectivamente a de preservar o pai como autoridade e identificação. Diante do pressuposto que o supereu constitui-se como herdeiro do complexo de Édipo, representando a saída necessária do mesmo, surge de imediato uma questão conflitante como conseqüência desta herança, ou seja, o duplo apelo paradoxal - “assim como o pai deves ser” e “assim como o pai não deves ser”, se por um lado institui a proibição do incesto e o lançamento de um ideal a ser buscado “modificando a temporalidade do desejo”, por outro, "não viabiliza a saída da casa paterna” ou, no mínimo, diríamos que a dificulta. (p.96)

Assim, Roberto coloca-se no manifesto de forma ativa, expulsando agressivamente este pai, onipotentemente, com ares de auto-suficiência e arrogância, de seu castelo narcísico onde reside com a rainha mãe. Como "traste” o pai não faz falta, não há porque lamentar a sua ausência “ deste objeto velho sem nenhum valor”. Este contexto familiar se manteria em plena harmonia, afastado o "traste" caso os aspectos conflitantes inerentes à filiação não se manifestassem, tanto na relação dual (mãe/filho) onde algo da contrariedade, do desafio se instala na tentativa de abrir caminho para uma saída da casa materna, como no contexto escolar/social, representativo da autoridade onde as normas de convivência implicam no seguimento por todos, das leis instituídas, exercício este que ancorado numa cobertura materna pôde se manter parcialmente escamoteado na história de Roberto, referimo-nos aqui a uma dimensão de consentimento compartilhado na desautorização ou legitimação de qualquer ato, lembremo-nos que mãe e filho sustentam o mesmo discurso.

Deparamo-nos com este espinhoso caminho da diferenciação entre autoridade e lugar do pai; Freud até o final de sua obra interroga-se sobre a questão da superação do pai da infância, tanto nas suas considerações a respeito do mecanismo da transferência e sua articulação com o término de uma análise, como na temática já referida e desenvolvida sobre a “nostalgia do pai” . 
Constatamos no caso Roberto os entraves que se condensam no supereu, entraves relativo às fronteiras, onde os limites são desafiados, relativos à lei (proibido/permitido), à ordenação (lugares/primeiro/segundo...) como que buscando demonstrar que o limite não se sustenta. Na figura do supereu Freud caracteriza a passagem do incesto - da relação privilegiada com a mãe à ordem social. Sabemos que esta passagem nunca é inteiramente concluída, embora no campo social sejamos convocados “diariamente” a testemunhá-la. Neste sentido, Roberto usufrui de garantias no terreno materno, promovedoras de satisfação imediata, no entanto no âmbito da fantasia sugere almejar um reconhecimento no terreno paterno/masculino (casa do Dragão Vermelho) terreno que comporta a sua agressividade, aqui projetada, campo temido e desejado (treinamento/lutas/morte), mas que paralelamente lhe permita um reconhecimento no meio social (exogâmico) e o consolide no seu processo identificatório. Por que via o traste/pai de sua vida poderia encaminhá-lo nesta empreitada, evidencia-se como um dos pólos das questões conflitantes em que Roberto se depara. Insistimos em nossa hipótese inicial sobre o caráter conflitante, em função da prevalência em seus comentários no sentido de destituir este pai, não se configurando assim, do ponto de vista interno, tão descartado por Roberto, cabendo-nos aqui a tarefa de estabelecer o diferencial com a estrutura perversa.

Em Fabinho o pai precisa ser reanimado, não desapareceu de cena, “está aí”, mas a muito custo se mantém presente. Laços identificatórios entre pai e filho (nhênhê-nhê) impedem um exercício efetivo da função deste pai para que retome o seu lugar e posicionamento, oferecendo-se como alvo da agressividade do filho e sobrevivendo apesar deste confronto, possibilitando um corte em sua onipotência infantil, colocando-se vivo e funcional perante ele e sua esposa. Lembremo-nos que até biologicamente os espermatozóides morriam, o que nos remete a hipótese de um traço melancólico frente a perda de sua própria mãe, cuja elaboração interna portanto, não tenha se processado. Sublinharemos novamente que a história dos pais (de seus lutos e seus desejos) é essencial no encaminhamento para os filhos de sua feminilidade ou masculinidade. 
Há um momento em que Fabinho consegue delinear algo que ele quer (tanto) ver mas que o aterroriza, trata-se do filme “Boneca Assassina”, sinalizando por um lado a angústia de castração ("La Cabeza de Medusa, 1940), por outro sinalizando as diferentes configurações do complexo paterno, neste sentido o seu posicionamento regressivo, sugerindo dificultar-lhe dinamicamente o encaminhamento de sua masculinidade.

Em Luciana, tudo transcorreria bem se ela não estivesse convocando um pai que faça valer a própria virilidade e diminua o tamanho destas mulheres enormes que tendem a engordar, já que este é o destino assustador que a ameaça, transformando-a a partir do traço identificatório nesta mãe/fálica, tão auto-suficiente., simultaneamente impondo-se uma “espécie de castigo” com este mal-estar vivido no corpo. Esta vivência de corpo imperfeito, esta importante ferida narcisista, aponta para a direção do complexo de castração (na menina), ou seja, a sua inveja do pênis, sendo toda carga afetiva de ressentimento em relação à mãe (que não foi capaz de poupá-la desta imperfeição), transferida ao pai e posteriormente serão os seus alvos nas futuras escolhas amorosas, conservando as cargas afetivas próprias do período pré-edípico.

Em “Inhibicion, Sintoma e Angustia” (1926) Freud já destaca a nutrição (como também, a inibição ao trabalho profissional, à função sexual e à motora) como as funções por onde a neurose se manifesta, com seu caráter sintomático. Refere que a compulsão de comer, resulta motivada pelo temor a morrer de fome, temor este que em última instância encontra-se representado na própria angústia de castração, pois não há como representar a morte, mas sim perdas, resignificada nas situações de separação em relação aos primeiros objetos, procurando o eu evitar a angústia por meio da formação de sintomas. Ressaltaremos que o sintoma constitui-se num símbolo, um substitutivo de uma expectativa de satisfação pulsional, um resultado do processo de recalcamento, onde o eu configura-se como a sede da angústia, daí a necessidade de caminhos alternativos para o sujeito manter-se minimamente preservado. 
Assim, no motivo da consulta definido como, ir mal na escola, entendemos que Luciana se aproxima via identificação/ quadro sintomático a este pai sem estudo (ignorante), criando algumas rachaduras neste conluio narcísico com a mãe que atribui ao pai o lugar de filho, de terceiro excluído ( numa posição complementar, consentida por este) retendo a filha para si , enquanto objeto fálico. Assim, tanto o desinteresse pelos estudos como a sua busca de amizades (que na lógica materna são qualificadas de inferiores) apontam para aspectos conflitantes de sua relação com as figuras parentais a partir desta trama edípica, especificamente com este pai tão rebaixado, buscando por estes atalhos e traços identificatórios, recuperá-lo em algum ponto de sua história, tendo visto que sua intensa raiva dele, tem sua contribuição nesta condição tão precária em que ele é colocado: sem teto, debaixo da ponte, "um desabrigado”. Neste sentido, o pai é o único necessitado, diante de mulheres fálicas que dispensam qualquer ajuda. Os "sintomas” de Luciana rompem esta dinâmica, dimensionando justamente a insuficiência desta montagem narcísica entre mãe e filha.

Caminhamos lado a lado com algumas passagens da clínica freudiana visando fundamentar esta articulação entre o lugar e a função do pai nas manifestações sintomáticas. Ressaltamos a importância de focalizar o pai enquanto lugar psíquico, apropriando-nos desta conceituação, como um instrumento a ser manejado dentro de uma escuta dos aspectos conflitantes aos quais somos confrontados na nossa prática. Apoiamo-nos neste terreno, cientes de que as interrogações e os enigmas devem sempre permear o horizonte do campo clínico. 


\title{
CONSIDERAÇÕES FINAIS
}

\author{
"Ao fim de todas as nossas explorações, \\ chegaremos ao ponto de partida, \\ conhecendo o lugar como que pela \\ primeira vez."
}

Entre rasuras e resenhas vamos chegando ao final deste longo trajeto, buscando estabelecer sempre os fundamentos que possam subsidiar da melhor forma a nossa prática.

Este estudo teve basicamente, na sua origem, dois eixos motivadores para o seu encaminhamento:

- o primeiro deles provém de um desejo, na medida em que é impossível subtrair-nos ao alvo de nossos interesses, a cada movimento que inauguramos, a tantas horas de dedicação e de investimento, inscrevemo-nos em nossos atos, em nossas palavras, única maneira de dar corpo aos nossos sonhos e anseios.

- o segundo deles partiu das inquietações que se manifestaram ao longo do trabalho clínico, ocorrendo um transbordamento de interesse como resultado da prática desenvolvida no contexto institucional, onde de um lado temos o sujeito, do outro o social. Esta circunstância, assim contextualizada, incitou-nos a estabelecer uma escuta de um campo mais amplo, na direção de um novo dimensionamento, comportando na sua respectiva abrangência reflexões e inquietações próprias do momento histórico/social em que nos encontramos. Posta esta perspectiva, obrigounos a revisões quanto ao encaminhamento do nosso trabalho, rompendo de certa maneira uma espécie de enclausuramento e fechamento que ilusoriamente nos pouparia desta árdua tarefa. 
Assim, abrimos alguns caminhos em diferentes direções, pretendemos nos dirigir para seu ponto comum, o entrecruzamento desta jornada. Esta é a face deste trabalho.

Neste sentido, houve primeiramente necessidade de estabelecermos um ancoramento preciso na teoria, através da literatura e principalmente de uma revisão da teoria freudiana, buscando com exemplificações na singularidade da clínica, o substrato e o fundamento necessários para darmos um salto e interrogarmo-nos sobre a questão paterna, não só no corpo a corpo dos atendimentos, mas na cultura e na contemporaneidade.

Assim sendo, partimos à procura de uma delimitação do lugar do pai na constituição da subjetividade da criança, estabelecemos um percurso longitudinal dentro da obra freudiana, permitindo-nos alguns ancoramentos em conceitos chaves que possibilitassem uma articulação do lugar e função do pai nas manifestações subjetivas encontradas na clínica. Na busca do caminho percorrido por Freud dentro de sua teoria, encontramos na sua leitura, o pai enquanto lugar psíquico na construção do psiquismo, permitindo-nos sublinhar sua importância para o estabelecimento de um raciocínio clínico quando articulado às manifestações sintomáticas, especificamente exemplificadas neste estudo, a partir do atendimento com crianças. A necessidade deste fundamento foi essencial para nos situarmos perante as manifestações subjetivas encontradas na nossa prática, visando a tradução ou a busca de sentidos para as diferentes problemáticas que hoje estão presentes no campo das relações entre pais e filhos.

Deste modo, reunimos alguns conceitos chaves para o desenvolvimento desta proposta como subsídio para a nossa escuta psicanalítica, buscamos sua elaboração dentro da obra freudiana, construção esta que não se encontra por ele sistematizada e assim ao estilo que lhe é próprio, quando chegamos ao final, passamos a entender e a nos fazer sentido o que está no início. Deste modo, respectivamente representados pelo inconsciente, pulsão, complexo de Édipo, complexo de castração, narcisismo e identificação, encontramos pilares conceituais de sustentação deste corpo teórico visando a consistência e uma direção ao exercício clínico, permitindo dispor de operatividade ao dimensionarmos o lugar do pai na subjetividade da criança. 
Mezan (1990) sintetiza com clareza a importância da questão paterna para Freud:
“...Na ambivalência dos sentimentos edipianos ele reconhecerá os contornos decisivos da figura do pai, não mais apenas como sedutor ou como objeto da fantasia, mas como elemento central da constituição do psiquismo humano... isto é, o processo pelo qual o homem se humaniza convertendo-se de um apêndice do corpo materno num indivíduo social, capaz de conviver com outros indivíduos sociais...” (p.265)

Com o material clínico ilustrativo, propusemo-nos a estabelecer a valorização da escuta psicanalítica destes pacientes já na formulação da queixa apresentada durante as entrevistas preliminares permitindo-nos transpor o campo psicanalítico para um trabalho institucional, ciente que as condições de demanda serão essenciais para o encaminhamento desta prática. Propomos pensar que este momento inaugural do psicodiagnóstico em termos institucionais, possibilita, por si só, abrir um espaço interventivo, promovido pela valorização desta escuta inicial da subjetividade que se manifesta, da leitura do inconsciente destacada das problemáticas e conflitos protagonizados no dia-a-dia. Assim, nestas entrevistas preliminares e mesmo nas próprias sessões, dirigimo-nos aos pais e à criança, "perguntando pelo acontecido não como um fim em si mesmo, mas como sinais do que deve ser compreendido e representado”. (Rosa,1995, p.172)

Estabelecemos que operar com os conceitos psicanalíticos nos permite estruturar um trabalho a partir de referenciais, ordenadores, e sustentadores para o encaminhamento de nossa prática. Deste modo, perante o atendimento, perguntarmonos sobre o lugar do pai nos auxilia a situar o sujeito frente a um dos sentidos de sua problemática. O material clínico apresentado, os fragmentos das entrevistas, tiveram como objetivo ilustrar a fecundidade dos estudos freudianos revelando o seu valor atual.

Ora, poderíamos ficar por aqui com tranqüilidade se não fosse a inquietação própria da Instituição, se não fossem o alvoroço, queixas, explosões de raiva e ressentimento que particularmente no contexto institucional sofrem uma ampliação. 
Em meio ao correspondente "alarde" e "gritaria” somos confrontados com a seguinte pergunta: afinal, onde está o pai?

Nos vemos situados entre a singularidade de cada atendimento realizado e a pluralidade representando e sinalizando um mal-estar que ao mesmo tempo nos atinge e nos transcende.

No campo clínico, concluímos que o pai está onde ele internamente (edipicamente) pode estar e onde a mãe da criança pode internamente permitir que ele esteja. Em princípio nada mais óbvio, não fossem os conflitos, os percalços, o mal-estar e a fragilidade estrutural do sujeito (seu desamparo) não teria nos preocupado tanto esta questão.

Neste ponto, somos interpelados e "convidados" a dar um salto para buscarmos o lugar do pai na História, na cultura, a respirar novos ares. Ao retomarmos esta trajetória, o que temos aqui não é nada de novo, pois inúmeras vezes esta questão tem sido feita pela vida afora - sinal da repetição dos "tempos", mas resta-nos ainda interrogações sobre o momento atual, porque esta "barulheira" hoje?

A clínica nos revela que é característico do neurótico queixar-se do pai, seja pelo seu domínio e tirania, seja pela sua insuficiência, seja maldizendo-o, seja numa devoção adoradora.

Ressalvas à parte, sentimo-nos capturados por este tumulto que claramente transparece no espaço institucional, concretamente na imagem onde todos querem "fazer terapia” - pelo menos esta é a expressão mais utilizada na porta de entrada ambulatorial, pedido este cujo peculiar está na superficialidade desta demanda, pois também querem um calmante, um revigorante, algo que atravessando as manifestações subjetivas da contemporaneidade, interpola-nos na clínica de modo geral, particularmente no atendimento com crianças e adolescentes através das dificuldades no estabelecimento dos limites, dos lugares e das ordenações, caracterizando-se por uma espécie de excesso que os pais "não conseguem” gerenciar sendo uma constante na nossa prática.

Lembremo-nos que a Instituição - neste caso do Estado, cumpre o seu papel também na transferência; assim profissionais e pacientes queixam-se o tempo todo do Estado/pai que não os acolhe como se esperaria (de um pai, é claro), mas impossível desfazer-se dele, a multiplicação de licenças, afastamentos favorecem esta perene permanência nesta casa, onde se fica pendurado. Lembremo-nos que no 
caso Roberto, em seu relato, ele nos dizia que estava à procura de um bico, considerações à parte sobre o sentido deste bico, constatamos que esta não é uma prerrogativa de Roberto, afinal, o vínculo com o Estado assume o lugar deste bico que a seu modo, alguma satisfação e garantia ainda promove. Assim a Instituição oferece uma de suas faces, campo de toda a ambigüidade que lhe é própria, compondo uma boa parcela do tumulto que nos abala na nossa prática.

Já não se trata aqui do pai da criança , o qual invocamos e nos referimos, trata-se do dimensionamento do pai na cultura, de seu lugar dentro de um imaginário social. Encontramos o eco deste alvoroço neste novo dimensionamento. Novamente, pudemos nos sentir plenamente acompanhados por Freud em sua busca no campo social/cultural destes mesmos referenciais. As múltiplas faces do pai, que não são poucas, têm seu transbordamento ao longo da história, numa composição variada, assim o Herói/Rei/Deus/Diabo/Profeta/Tirano, incorporado na Política, na Religião, na Justiça, na Ciência, nos permite visualizar as diferentes posições desta figura.

Freud nas suas investidas por terras alheias, diríamos, mas também barulhentas, nos faz percorrer desde a origem de um mito, mito do pai da horda primitiva, passando pela elevação máxima do pai na figura de Deus, até seu desencanto com a morte, na referida "nostalgia do pai”, lembrando-nos de nosso desamparo inerente à condição humana.

Chegamos à "humilhação" do pai, seu “declínio" até à sua "morte” enquanto figura social centralizadora e unificadora. Lembremo-nos que segundo o próprio Freud, o pai morto é pior que o pai vivo, e neste sentido os ecos deste malestar não são casuais.

Pensamos que neste momento na sobreposição entre ambos os campos - do público e do privado - as questões individuais conflituadas não encontram no social algum tipo de sustentação que as acolha, haja barulho na busca de ordenadores que promovam demarcações.

Consta que os pais não "sabem" mais o que fazer, diluíram-se os referenciais outrora solidificados, mas na sua projeção idealizada, a Medicina, a Psicologia, na face da ciência, sabem. Assim, os pais desfazem-se de suas incertezas e projetam o seu ideal neste imaginário social que se presta a dar respostas e garantias; em suma, abdicam de seu posto. Pensamos que seduzidos por este lugar em que somos colocados - lugar este poderoso/fálico, nossa função possa deslizar 
para um efeito iatrogênico, sendo necessário um cuidado sistemático na revisão do nosso trabalho, mais ainda, de uma Ética

A necessidade de corresponder à algumas destas faces, diz respeito à singularidade de cada caso, à dinâmica que lhe é intrínseca, à rede familiar em que a subjetividade se origina...fios afetivos nesta malha composta de laços e nós desafetos...

Conduzimos este trabalho tendo, como pano de fundo, os diferentes momentos ditados pela História a partir de suas transformações. Vimos que o lugar do pai é nômade, ora ocupa um espaço, ora translada-se através das diferentes épocas, assim, desde a imensidão do universo, no lugar de Deus situado entre os grandes astros e estrelas até sua redução, numa unidade mínima, partícula de matéria viva, mais precisamente: congelada.

Ao considerarmos a constituição do sujeito, agora, desde o pai no exercício de seu lugar e função perante a criança, também lhe cabe ocupar distintos lugares grandes e pequenos que ficam inscritos e sinalizados na singularidade das histórias, nos diferentes conflitos e queixas: matriz subjetiva da nossa prática.

Trabalhamos neste estudo num movimento polarizado, procurando nos situar dentro deste continuum, assim caminhamos do sujeito para o grupo, do psíquico para o social, do privado para o público, da singularidade para a pluralidade, da normalidade para a patologia, portanto estamos navegando (para sermos atuais) dentro do desassossego próprio dos novos tempos, de um movimento sempre conflituado, composto de agitação e ventanias. Assim, chegam ao Ambulatório de Psiquiatria e Psicologia Médica, pais e crianças em meio a este tumulto em busca de gerenciar o mal-estar próprio dessas relações, em busca de algo que possa banir e exorcizar o sofrimento da condição humana.

As diferentes épocas proporcionam novas versões de um mesmo tema que tanto no individual como no social se repetem. Este estudo teve como meta chegar ao ponto de entrecruzamento destes espaços, motivado pelas inquietações da nossa prática. Enquanto psicanalistas, nosso posicionamento é de questionamento contínuo, “é de convivência com as incertezas e impossibilidades, exigência derivada de seu próprio objeto - o trabalho com o inconsciente e, portanto, com o desconhecido, o não sabido, o irrepresentável.” (Cavalcanti et alli.,2000, p.115) 
Mais do que respostas, buscamos precisar alguns contornos a respeito do nosso propósito até aqui traçado: o lugar do pai e seus impasses na subjetividade, na clínica e na contemporaneidade. Doravante, deixamos em aberto a perspectiva de um aprofundamento do tema abordado, particularmente no que se refere ao espaço de atuação dentro de uma Instituição - instância social em que também se inscreve o sujeito.

Pensamos que há sempre um ângulo a ser explorado.

Em nome da relevância deste trabalho para a comunidade que o busca e dele necessita, devidamente respaldados com a teoria e a clínica, há de surgir novos propósitos neste vasto horizonte do campo das Instituições, buscando compreender a sua dinâmica, seus alcances e seus entraves, suas resistências e suas vicissitudes quanto ao lugar que lhe é outorgado, sua coerência e os dispositivos Éticos que dispõe como oferta de sustentação para o sujeito.

Retratamos algo que diz respeito ao interminável e portanto, nos angustia pela exigência contínua de construção e produção de sentido frente aos impasses que à nossa prática não nos cabe subtrair.

Retiramo-nos deste estudo, dando a palavra a Freud num fugaz comentário em “Moises y la Religion Monoteísta” (1939, p.3250):

“...Sin embargo, todo lo nuevo debe hallar antecedentes y

condiciones previas em hechos anteriores..." 


\section{REFERÊNCIAS BIBLIOGRÁFICAS}

ABERASTURY, A.(1979). Psicanálise da criança - Teoria e técnica. Porto Alegre, Artes Médicas, 1982.

.; SALAS, E.J. A paternidade. Um enfoque analítico. Porto

Alegre, Artes Médicas, 1984.

ANTELO, E. Dos impasses às vicissitudes educativas. In: A PSICANÁLISE, A EDUCAÇÃO E OS IMPASSES DA SUBJETIVAÇÃO NO MUNDO MODERNO, II., São Paulo, 2000. Anais. São Paulo, Lugar de Vida/Lepsi, Instituto de Psicologia/ F.E. da Universidade de São Paulo, 2000. p.31-35.

ARIÈS, P. História social da criança e da família. Rio de Janeiro, Zahar, 1978.

BIRMAN, J. Psicanálise, uma estilística da existência? In: Por uma Estilística da Existência. São Paulo. Trinta e quatro, 1996, p.23-48.

- A modernidade e a função paterna. In: A PSICANÁLISE, A EDUCAÇÃO E OS IMPASSES DA SUBJETIVAÇÃO NO MUNDO MODERNO, II., São Paulo, 2000. Anais. São Paulo, Lugar de Vida/Lepsi Instituto de Psicologia/ F.E. da Universidade de São Paulo, 2000. p.36-41.

Insuficientes, um esforço a mais para sermos irmãos! In: KEHL, M.R., org. Função fraterna. Rio de Janeiro, Relume Dumará, 2000.

BLANES, B.N. As identificações no contexto da supervisão clínica. São Paulo, PUC SP, 1989, 15p. [Datilografado] .

BLEGER, J. El problema metodológico en psicología. In: Psicología de la conducta. 7.ed. Buenos Aires, Paidós, 1976. Cap.XV, p.215- 237.

A entrevista psicológica. In: Temas de Psicologia: entrevistas e grupos. Buenos Aires, Departamento de Psicologia da Faculdade de Filosofia e Letras. Universidade de Buenos Aires, 1964. p.9-41.

BLEICHMAR, S. A fundação do inconsciente: destinos de pulsão, destinos do sujeito. Porto Alegre, Artes Médicas, 1994.

CALLIGARIS, C.; et al. Educa-se uma criança? Porto Alegre, Artes e Ofícios, 1994.

CARVALHO, L.A. Reflexões sobre o pai - Um estudo sobre a construção da paternidade na história de vida e no desenvolvimento do sujeito. São Paulo, 1989, 185p. Dissertação (Mestrado) Instituto de Psicologia, Universidade de São Paulo. 
CAVALCANTI, A.E.; CARDOSO,C., ROCHA,P.S. Reflexões sobre a instituição psicanalítica na contemporaneidade. In: KEHL, M.R., org. Função fraterna. Rio de Janeiro, Relume Dumará, 2000.

CHATEL, M.M. Mal-Estar na Procriação: as mulheres e a medicina da reprodução.Rio de Janeiro, Campo Matêmico,1995.

CHAUÍ, M. As ciências. In: Convite à Filosofia. São Paulo, Ática, 1996, p. 247287.

COSTA,A.M.M. Autoridade e legitimidade. In: KEHL, M.R., org. Função fraterna. Rio de Janeiro, Relume Dumará, 2000.

DOLTO, F. (1965). Prefácio. In: MANNONI, M. A Primeira entrevista em Psicanálise 5.ed. Rio de Janeiro, Campus, 1986.

No jogo do desejo. Rio de Janeiro, Zahar, 1984.

.(1971) Psicanálise e Pediatria. 4.ed. Rio de Janeiro, LTC, 1988

DOR, J. O pai e sua função em psicanálise. Rio de Janeiro, Zahar, 1991.

Estruturas e clínica psicanalítica. 3.ed. Rio de Janeiro, Taurus, 1994.

DRUMMOND,C. D. Reunião: 10 livros de poesia. Rio de Janeiro, J. Olympio, 1974.

DUPUIS, J. Em nome do pai - uma história da paternidade. São Paulo, Martins Fontes, 1989.

ELIOT, T.S. Quatro Quartetos. In: O universo como laboratório. GLEISER, M. Folha de São Paulo. São Paulo, 22 dez. 20002. Caderno Mais, n.567, p.18.

FINE, R. A história da psicanálise. São Paulo, Universidade de São Paulo, 1981.

FLEIG, M. A tese do declínio da imago social do pai e o deslocamento da autoridade. In: A PSICANÁLISE, A EDUCAÇÃO E IMPASSES DA SUBJETIVAÇÃO NO MUNDO MODERNO, II., São Paulo, 2000. Anais. São Paulo, Lugar de Vida/ Lepsi, Instituto de Psicologia/ F.E. da Universidade de São Paulo, 2000. p.21-30

FERREIRA, A.B.H. Pai/Paternidade. In: Novo dicionário da língua portuguesa. Rio de Janeiro, Nova Fronteira, 1975. p.1026/1055

FREUD, S. (1895). Estudios sobre la histeria. In: Obras Completas. Trad. Luis Lopez-Ballesteros y de Torres. 4.ed. Madrid, Biblioteca Nueva, 1981. v.1, p.39168. 
(1895). Proyecto de una psicología para neurólogos. In: Obras Completas. Trad. Luis Lopez-Ballesteros y de Torres. 4.ed. Madrid, Biblioteca Nueva, 1981. v.1, p.209-76

. (1896). Los Origenes del psicoanalisis. Carta 52, Carta 71. In: Obras Completas.Trad.Luis Lopez-Ballesteros y de Torres. 4.ed. Madrid, Biblioteca Nueva, 1981.v.3, p.3551-56.

(1900). La interpretacion de los sueños. In: Obras Completas. Trad. Luis Lopez-Ballesteros y de Torres. 4.ed. Madrid, Biblioteca Nueva, 1981. v.1, Cap. V, VI, VII, p.447-720.

(1905). Tres ensayos para una teoria sexual. In: Obras Completas. Trad. Luis Lopez-Ballesteros y de Torres. 4.ed. Madrid, Biblioteca Nueva, 1981. v.2, p.1172-1237.

. (1905). Analisis fragmentario de una histeria (Caso Dora). In: Obras Completas. Trad. Luis Lopez-Ballesteros y de Torres. 4.ed. Madrid, Biblioteca Nueva, 1981. v.1. p.934-1002.

(1908). Teorias sexuales infantiles. In: Obras Completas. Trad. Luis Lopez-Ballesteros y de Torres. 4.ed. Madrid, Biblioteca Nueva, 1981. v.2, p.1262-71.

(1909). La Novela Familiar Del Neurótico. In: Obras Completas. Lopez-Ballesteros y de Torres. 4.ed. Madrid, Biblioteca Nueva, 1981. v.2, p.1361-63

(1909). Analisis de la fobia de un ninõ de cinco años (Caso Juanito). In: Obras Completas. Trad. Luis Lopez-Ballesteros y de Torres. 4.ed. Madrid, Biblioteca Nueva, 1981. v.2, p.1365-1440.

(1909). Analisis de un caso de neurosis obsesiva (Caso el Hombre de las ratas). In: Obras Completas. Trad. Luis Lopez-Ballesteros y de Torres. 4.ed. Madrid, Biblioteca Nueva, 1981. v.2, p.1441-86.

(1910). Cinco conferencias del Psicoanalisis. In: Obras Completas. Trad. Luis Lopez-Ballesteros y de Torres. 4.ed. Madrid, Biblioteca Nueva, 1981. v.2, $4^{\mathrm{a}}$ conf., p.1553-59.

(1910). Un recuerdo infantil de Leonardo de Vinci. In: Obras Completas. Trad. Luis Lopez-Ballesteros y de Torres. 4.ed. Madrid, Biblioteca Nueva, 1981. v.2, p.1578-1619.

. (1910). Sobre un tipo especial de la elección de objeto en el hombre. In: Obras Completas. Trad. Luis Lopez-Ballesteros y de Torres. 4.ed. Madrid, Biblioteca Nueva, 1981. v.2, p.1625-30. 
(1911). Observaciones psicoanalíticas sobre um caso de paranóia (Caso Schreber). In: Obras Completas. Trad. Luis Lopez-Ballesteros y de Torres. 4.ed. Madrid, Biblioteca Nueva, 1981. v.2, p.1487-1528.

. (1912). Consejos al médico em el tratamiento psicoanalítico. In: Obras Completas. Trad. Luis Lopez-Ballesteros y de Torres. 4.ed. Madrid, Biblioteca Nueva, 1981. v.2, p.1654-60.

(1912-3). Totem y tabu. In: Obras Completas. Trad. Luis LopezBallesteros y de Torres. 4.ed. Madrid, Biblioteca Nueva, 1981. v.2, p.17451850.

(1913). La iniciación del tratamiento. In: Obras Completas. Trad. Luis Lopez-Ballesteros y de Torres. 4.ed. Madrid, Biblioteca Nueva, 1981. v.2, p.1661-74.

. (1914). Recuerdo, Repeticion y Elaboracion. In: Obras Completas. Trad. Luis Lopez-Ballesteros y de Torres. 4.ed. Madrid, Biblioteca Nueva, 1981. v.2, p.1683-88.

- (1914). Introduccion al narcisismo. In: Obras Completas. Trad. Luis Lopez-Ballesteros y de Torres. 4.ed. Madrid, Biblioteca Nueva, 1981. v.2, p.2017-33.

. (1915). Los instintos y sus destinos. In: Obras Completas. Trad. Luis Lopez-Ballesteros y de Torres. 4.ed. Madrid, Biblioteca Nueva, 1981. v.2, p.2039-52.

.(1915). La represion. In: Obras Completas. Trad. Luis LopezBallesteros y de Torres. 4.ed. Madrid, Biblioteca Nueva, 1981. v.2, p.2053-60.

(1915). Lo inconsciente. In: Obras Completas. Trad. Luis LopezBallesteros y de Torres. 4.ed. Madrid, Biblioteca Nueva, 1981. v.2, p.2061-82.

. (1916). Lecciones introductorias al psicoanalisis. In: Obras Madrid, Completas. Trad. Luis Lopez-Ballesteros y de Torres. 4.ed. Biblioteca Nueva, 1981. v.2, XXI leccion, p.2322-34.

(1917). Sobre las transmutaciones de los instintos y especialmente del erotismo anal. In: Obras Completas. Trad. Luis Lopez-Ballesteros y de Torres. 4.ed. Madrid, Biblioteca Nueva,1981. v.2, p. 2034-38.

(1917). Duelo y melancolia. In: Obras Completas. Trad. Luis LopezBallesteros y de Torres. 4.ed. Madrid, Biblioteca Nueva, 1981. v.2, p.2091-2100.

. (1918). História de una neurosis infantil (Caso del Hombre de los Lobos). In: Obras Completas. Trad. Luis Lopez-Ballesteros y de Torres. 4.ed. Madrid, Boblioteca Nueva, 1981,v.2, p.1941-2009. 
(1920). Mas alla del principio del placer. In: Obras Completas. Trad. Luis Lopez-Ballesteros y de Torres. 4.ed. Madrid, Biblioteca Nueva, 1981. v.3, p.2507-41.

- (1921). Psicología de las masas y analisis del yo. In: Obras Completas. Trad. Luis Lopez-Ballesteros y de Torres. 4.ed. Madrid, Biblioteca Nueva, 1981. v.3, p.2563-2610.

(1923). Una neurosis demoníaca en el siglo XVII. In: Obras Completas. Trad. Luis Lopez-Ballesteros y de Torres. 4.ed. Madrid, Biblioteca Nueva, 1981. v.3, pp.2677-96.

(1923). La organización genital infantil. In: Obras Completas. Trad. Luis Lopez-Ballesteros y de Torres. 4.ed. Madrid, Biblioteca Nueva, 1981. v.3, p.2698-2700.

(1923). El yo y el ello. In: Obras Completas. Trad. Luis LopezBallesteros y de Torres. 4.ed. Madrid, Biblioteca Nueva, 1981. v.3, p.2701-28.

(1924). La disolución del complejo de Edipo. In: Obras Completas. Trad. Luis Lopez-Ballesteros y de Torres. 4.ed. Madrid, Biblioteca Nueva, 1981. v.3, p.2748-51.

(1925). Autobiografia. In: Obras Completas. Trad. Luis LopezBallesteros y de Torres. 4.ed. Madrid, Biblioteca Nueva, 1981. v.3, p.2761-99.

(1925). Algunas consecuencias psíquicas de la diferencia sexual anatômica. In: Obras Completas. Trad. Luis Lopez-Ballesteros y de Torres. 4.ed. Madrid, Biblioteca Nueva, 1981. v.3, p.2896-2903.

(1926). Inhibicion, sintoma y angustia. In: Obras Completas. Trad. Luis Lopez-Ballesteros y de Torres. 4.ed. Madrid, Biblioteca Nueva, 1981. v.3, p.2833-83.

. (1927). El porvenir de uma ilusion. In: Obras Completas. Trad. Luis Lopez-Ballesteros y de Torres. 4.ed. Madrid, Biblioteca Nueva, 1981. v.3, p.2961-92.

. (1927). Fetichismo. In: Obras Completas. Trad. Luis Lopez-Ballesteros y de Torres. 4.ed. Madrid, Biblioteca Nueva, 1981. v.3, p.2993-96.

(1928). Dostoyevski y el parricídio. In: Obras Completas. Trad. Luis Lopez-Ballesteros y de Torres. 4.ed. Madrid, Biblioteca Nueva, 1981. v.3, p.3004-15.

. (1930). El malestar em la cultura. In: Obras Completas. Trad. Luis Lopez-Ballesteros y de Torres. 4.ed. Madrid, Biblioteca Nueva, 1981. v.3, p. 3017-67. 
(1931). Sobre la sexualidad feminina. In: Obras Completas. Trad. Luis Lopez-Ballesteros y de Torres. 4.ed. Madrid, Biblioteca Nueva, 1981. v.3, p.3077-89.

. (1933). La feminidad. Nuevas lecciones introductorias al psicoanalisis. In: Obras Completas. Trad. Luis Lopez-Ballesteros y de Torres. 4.ed. Madrid, Biblioteca Nueva, 1981. v.3, p.3164-78.

- (1939). Moises y la religion monoteísta: tres ensayos. In: Obras Completas. Trad. Luis Lopez-Ballesteros y de Torres. 4.ed. Madrid, Biblioteca Nueva, 1981. v.3, p.3241-3324.

. (1940). La cabeza de medusa. In: Obras Completas. Trad. Luis LopezBallesteros y de Torres. 4.ed. Madrid, Biblioteca Nueva, 1981. v.3, p.2697.

GARCIA-ROZA, L.A. Introdução à Metapsicologia Freudiana. Rio de Janeiro, Zahar, 1991. v.1.

GOMES, I..C. O sintoma da criança e a dinâmica do casal. São Paulo, Escuta, 1998.

GOLDGRUB, F. O complexo de Édipo. São Paulo, Ática,1989.

HARTMANN, H. Ego Psychology and the problem of adaptation. New York, International Univs. Press, 1939.

HERMANN, F. Mal-estar na cultura e a psicanálise no fim do século. In: JUNQUEIRA $F^{\circ}$, L.C.U., coord.. Perturbador mundo novo: história, psicanálise e sociedade contemporânea: 1492, 1900, 1992. São Paulo, Escuta, 1994. p.305-333.

JERUSALINSKY, A. Sintomas de infância. In: Boletim APPA. Porto Alegre, Ano2, n.5, 1991.

uma criança? Porto Alegre, Artes e Ofícios,1994. p.5-23.

- A função paterna e o mundo moderno. In: A PSICANÁLISE, A EDUCAÇÃO E OS IMPASSES DA SUBJETIVAÇÃO NO MUNDO MODERNO, II., São Paulo, 2000. Anais. São Paulo, Lugar de Vida/Lepsi, Instituto de Psicologia/ F.E. da Universidade de São Paulo, 2000. p.15-20.

JULIEN,P. O manto de Noé - Ensaio sobre a paternidade. Rio de Janeiro, Revinter, 1997.

KEHL,M.R. org. Função fraterna. Rio de Janeiro, Relume Dumará, 2000.

KLEIN, M. (1932). Psicanálise da Criança. 3ed. São Paulo, Mestre Jou, 1981. (1957). Inveja e gratidão. Rio de Janeiro. Imago,1974. 
KUNDERA, M. A insustentável leveza do ser. São Paulo, C. das Letras, 1999.

LACAN, J. (1938). A Família. Lisboa, Assírio e Alvim, 1981.

(1949). O estádio do espelho como formador da função do eu. In: Escritos. Rio de Janeiro, Zahar, 1998. p.96-103.

(1953) Função e campo da fala e da linguagem em psicanálise. In: Escritos. Rio de Janeiro, Zahar, 1998. p. 238-323.

(1955-56). De uma questão preliminar a todo tratamento possível da psicose. In: Escritos. Rio de Janeiro, Zahar, 1998. p.537-90. 1998. p869-92.

LAPLANCHE, J.; PONTALIS, J.-B. Vocabulário da Psicanálise. 7.ed. São Paulo, Martins Fontes, 1983.

LÉVI-STRAUSS, C. As estruturas elementares do parentesco. 2.ed. Rio de Janeiro, Vozes, 1982.

MANNONI, M. (1965). A Primeira entrevista em psicanálise. 5.ed. Rio de Janeiro, Campus, 1986.

MELMAN, C. Sobre a educação das crianças. In: CALLIGARIS, C., org. Educa-se uma criança? Porto Alegre, Artes e Ofícios, 1994. p.31-40.

MELO NETO, J. C. Os melhores Poemas. São Paulo, Global, 1985.

MENCONI, D. Competição com Deus. Isto é, nº 1736, p.76-8, jan,2003.

MENEZES,L.C. O homem dos ratos e a questão do pai. Percurso, v.3.n.5/6, p. 713,1991 .

MEZAN, R. Freud, Pensador da Cultura. 5.ed São Paulo, Brasiliense, 1990.

Pesquisa com material clínico. In: Psicanálise e Universidade, Cadernos, PUC, São Paulo, 1992.

MIGUELEZ, N.B.S. A Interpretação. Boletim. Formação em Psicanálise. Instituto. Sedes Sapientiae, São Paulo, v.8/9,n.2/1, p.7-12, 2000.

MIGUELEZ, O.M. Narcisismo na obra de Freud (versão preliminar). São Paulo. Formação em Psicanálise. Instituto Sedes Sapientiae, 1997, 18p. \{ Datilografado\} 
Ogden: uma leitura. Boletim, Formação em Psicanálise.Instituto. Sedes Sapientiae, São Paulo, Ano VII, vol.VII, n.2, 1998.

. Narcisismo, religião e cultura: as torres gêmeas. Apresentado no Terceiro Encontro Latino Americano dos Estados Gerais da Psicanálise. Buenos Aires, Argentina, nov. 2002. Disponível na Internet: http://www.estadosgerais.org/ $\{13$ jan.2003\}

PRISZKULNIK, L. As entrevistas diagnósticas em psicanálise. Psychê, São Paulo, ano2, n.2, p.17-23, 1998.

PULSIONAL REVISTA DE PSICANÁLISE. O lugar do pai. São Paulo, Livraria Pulsional, Ano XIII, n.136, 2000.

RAMADAM, Z.B. Sexualidade, religião e misticismo. TEMAS - Teoria e Prática Do Psiquiatra. São Paulo, Grupo de Estudos Psiquiátricos do Hospital do Servidor Público Estadual "Francisco Morato De Oliveira", v.26,n.52,p.164-72, 1996.

RASSIAL, J.J. Declínio do pai ou falha do professor. In: A PSICANÁLISE, A EDUCAÇÃO E OS IMPASSES DA SUBJETIVAÇÃO NO MUNDO MODERNO, II., São Paulo, 2000. Anais. São Paulo, Lugar de Vida/Lepsi, Instituto de Psicologia/ F.E. da Universidade de São Paulo, 2000. p.9-14.

ROSA, M.D. A psicanálise frente a questão da identidade. Revista Psicologia e Sociedade, v.10, n.1. Pontifícia Universidade Católica.

O não-dito e a psicanálise com crianças. São Paulo, 1995. 180p. Tese (Doutorado) - Pontifícia Universidade Católica de são Paulo.

ROSENBERG, A.M.S. O lugar dos pais na psicanálise de crianças. São Paulo, Escuta, 1994.

ROUDINESCO, E.; PLON, M. Dicionário de Psicanálise. Rio de Janeiro, Zahar, 1998.

. Por que a psicanálise? Rio de Janeiro, Zahar, 2000.

SAFRA, G. Pesquisa com material clínico. In: Psicanálise e Universidade, Cadernos, PUC, São Paulo, 1992.

SILVA, A.S.B.P. O papel da figura paterna na formação de personalidade: um estudo com adolescentes toxicômanos. São Paulo, 1990, 272p. Tese (Doutorado) - Instituto de Psicologia, Universidade de São Paulo.

SILVA, M.S.A.N. Em busca do elo perdido: escuta psicanalítica para histórias de adoção. São Paulo, 2001. 164p. Dissertação(Mestrado) Instituto de Psicologia, Universidade de São Paulo.

SILVEIRA, P. org. Exercício da paternidade. Porto Alegre, Artes Médicas, 1998. 
SONENREICH, C.; ESTEVÃO, G. Psiquiatria no Hospital Geral: Atividades no Hospital do Servidor Público Estadual "Francisco Morato de Oliveira”. Temas Teoria e Prática Do Psiquiatra. São Paulo, Grupo de Estudos Psiquiátricos do Hospital do Servidor Público Estadual "Francisco Morato De Oliveira", v.26,n.52, p.189- 208, 1996.

THIS, B. O pai: ato de nascimento. Porto Alegre, Artes Médicas, 1987.

TRINCA, W. O pensamento clínico em diagnóstico da personalidade. Rio de Janeiro, Vozes, 1983.

UNIVERSIDADE DE SÃO PAULO. Instituto de Psicologia, Serviço de Biblioteca e Documentação. Normalização de referências bibliográficas: Manual de Orientação. São Paulo, 1997.

Instituto de Psicologia, Serviço de Biblioteca e Documentação. Citações no texto e notas de rodapé: Manual de Orientação. São Paulo, 1997.

Instituto de Psicologia, Serviço de Biblioteca e Documentação. Diretrizes para a elaboração de dissertações e teses. São Paulo, 1999.

WINNICOTT, D.W. (1958). O brincar e a realidade. Rio de Janeiro, Imago, 1975. Biblioteca Nueva, 1981. v.2, p.1941-2009. 